Prepared in cooperation with the National Park Service

Numerical Simulation of the Effects of Groundwater Withdrawal and Injection of High-Salinity Water on Salinity and Groundwater Discharge, Kaloko-Honokōhau National Historical Park, Hawai'i

Scientific Investigations Report 2021-5004 
Cover. Groundwater in Kaloko-Honokōhau National Historical Park, Hawai'i, forms 'Aimakapā fishpond-a land-locked coastal water body that provides habitat for endangered native waterbirds and that is separated from the ocean by a sand berm—and smaller anchialine pools (inset; pool is about 3 feet wide and a few inches deep), which occur in surface depressions in the volcanic rocks that extend below the groundwater table. Photographs by Delwyn S. Oki, U.S. Geological Survey, May 14, 2012. 


\section{Numerical Simulation of the Effects of Groundwater Withdrawal and Injection of High-Salinity Water on Salinity and Groundwater Discharge, Kaloko- Honokōhau National Historical Park, Hawai'i}

By Delwyn S. Oki

Prepared in cooperation with the National Park Service

Scientific Investigations Report 2021-5004

U.S. Department of the Interior

U.S. Geological Survey 


\section{U.S. Geological Survey, Reston, Virginia: 2021}

For more information on the USGS-the Federal source for science about the Earth, its natural and living resources, natural hazards, and the environment-visit https://www.usgs.gov or call 1-888-ASK-USGS.

For an overview of USGS information products, including maps, imagery, and publications, visit https://store.usgs.gov.

Any use of trade, firm, or product names is for descriptive purposes only and does not imply endorsement by the U.S. Government.

Although this information product, for the most part, is in the public domain, it also may contain copyrighted materials as noted in the text. Permission to reproduce copyrighted items must be secured from the copyright owner.

Suggested citation:

Oki, D.S., 2021, Numerical simulation of the effects of groundwater withdrawal and injection of high-salinity water on salinity and groundwater discharge, Kaloko-Honokōhau National Historical Park, Hawai'i: U.S. Geological Survey Scientific Investigations Report 2021-5004, 59 p., https://doi.org/10.3133/sir20215004.

Associated data for this publication:

Oki, D.S., 2021, SUTRA model used to evaluate the effects of groundwater withdrawal and injection, KalokoHonokōhau National Historical Park, Hawai'i: U.S. Geological Survey data release, https://doi.org/10.5066/P9IZ3EVJ.

ISSN 2328-0328 (online) 


\section{Acknowledgments}

Funding for this study was provided by the National Park Service (NPS), Water Rights Branch and Kaloko-Honokōhau National Historical Park (KAHO). Paula Cutillo, Sallie Beavers, Rebecca Most, and Lindsey Kramer from NPS assisted with field logistics, data collection, and other aspects of the study. Ed Carlson from the National Geodetic Survey determined altitudes of reference marks near wells using global positioning system methods. Tom Nance (Tom Nance Water Resource Engineering) provided data from wells near KAHO that were invaluable for understanding the groundwater-flow system. Keith Olson from the Natural Energy Laboratory of Hawaii Authority (NELHA) provided water-quality and water-quantity information related to the NELHA facility; Norris Uehara from the Hawai' $i$ Department of Health, Safe Drinking Water Branch, provided data from injection wells in the study area; Patrick Casey and Robert Chenet from the Hawai'i Commission on Water Resource Management provided water-level, salinityprofile, and groundwater-withdrawal data from wells in and near the study area. Jeff Perreault, Sarah Rosa, Adam Johnson, Maoya Bassiouni, and Craig Senter from the U.S. Geological Survey (USGS) and Kolja Rotzoll, at the time with the University of Hawai'i (currently with USGS), helped in collection of water-level data and surveying. 


\section{Contents}

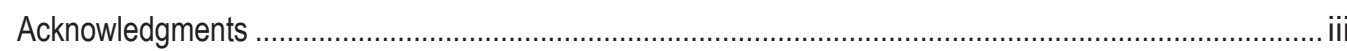

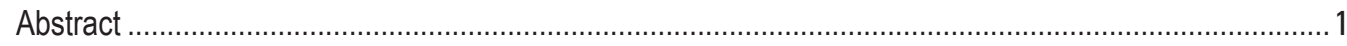

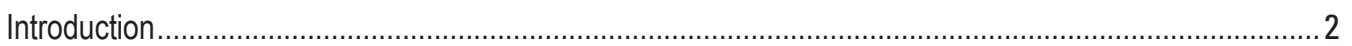

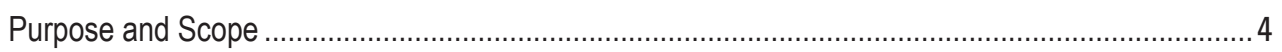

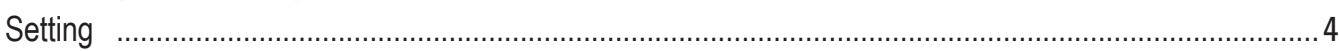

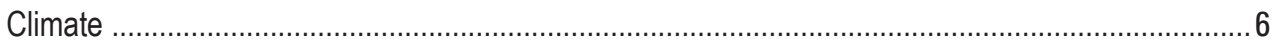

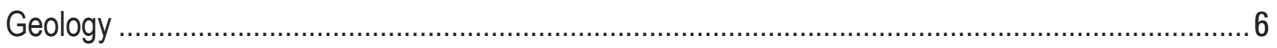

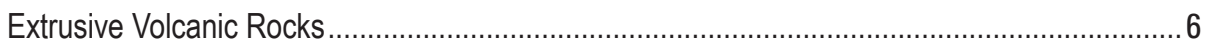

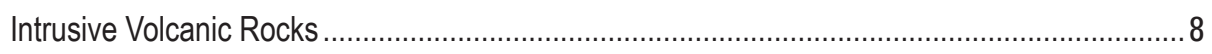

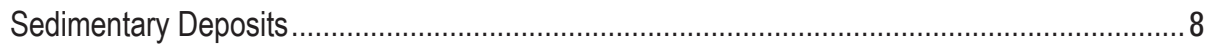

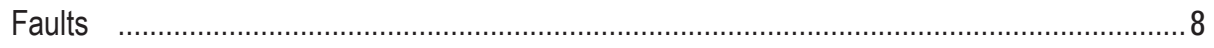

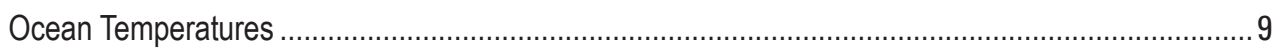

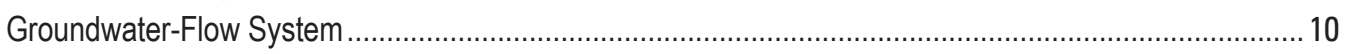

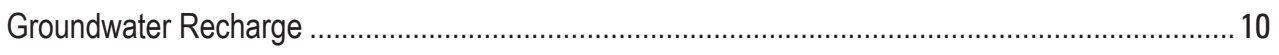

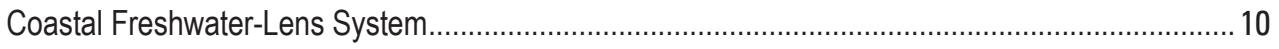

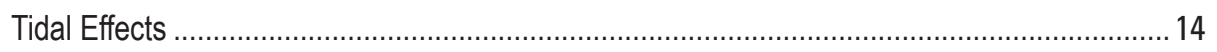

Synoptic Water-Level Distribution ............................................................................ 18

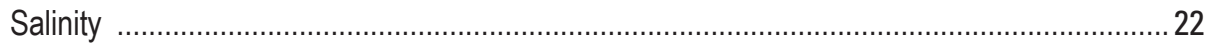

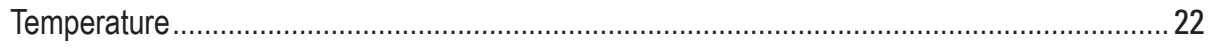

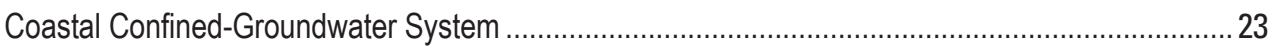

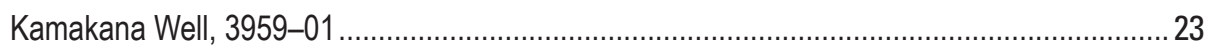

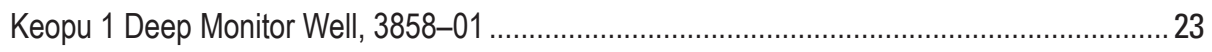

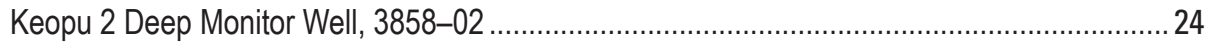

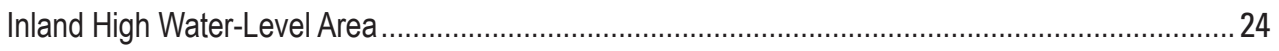

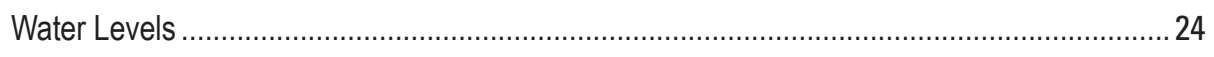

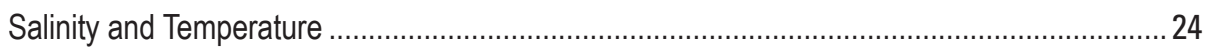

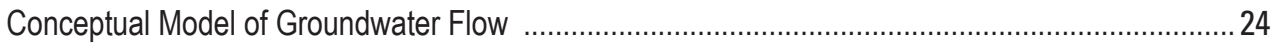

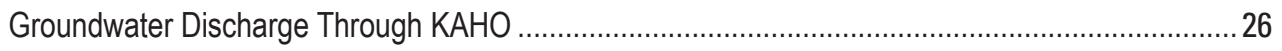

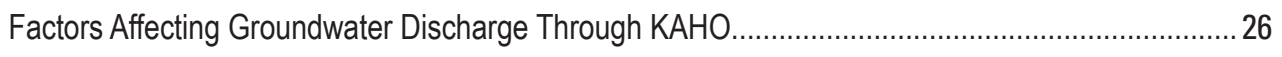

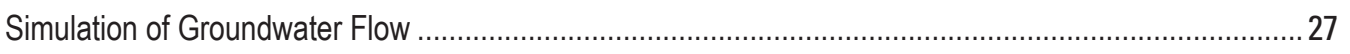

Water Properties

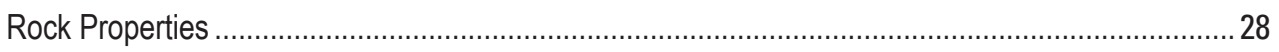

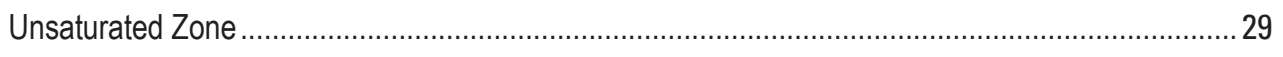

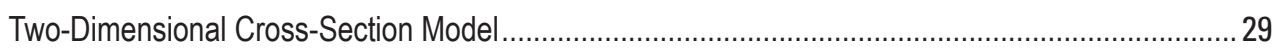

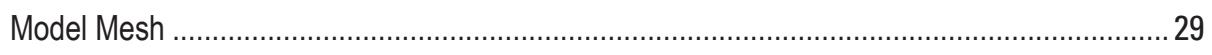

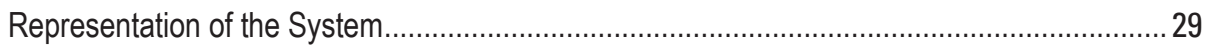

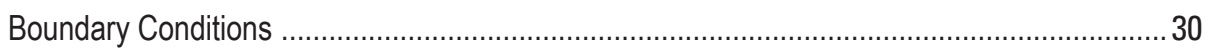

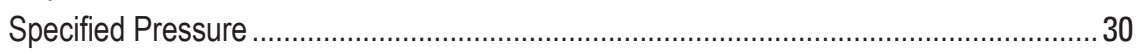

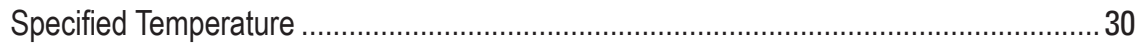

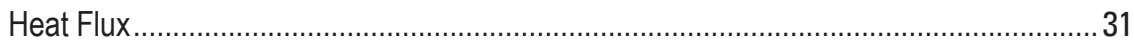

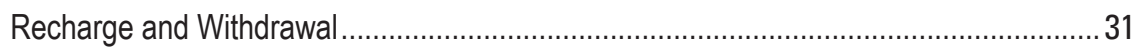

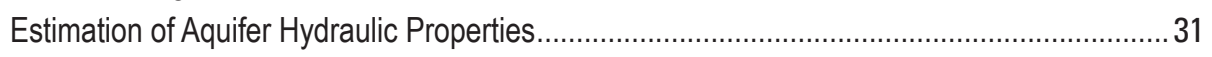

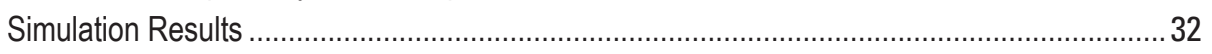




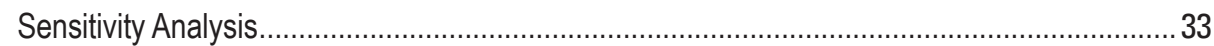

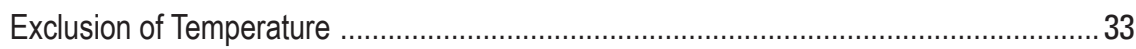

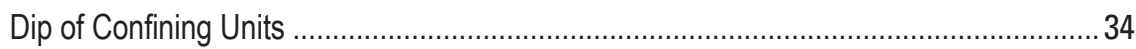

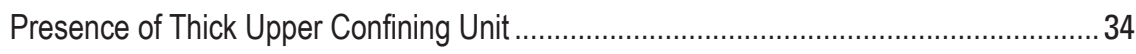

Exclusion of Confining Units and Recharge from Inland Vertical Boundary......................34

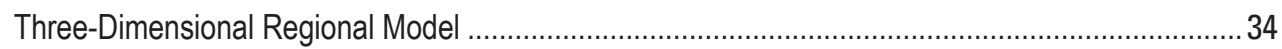

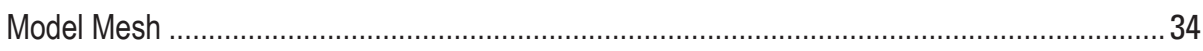

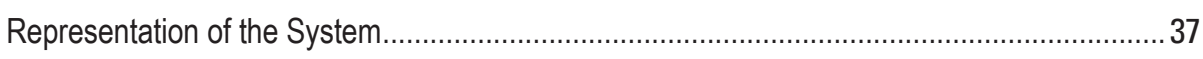

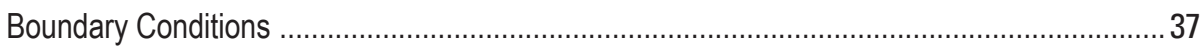

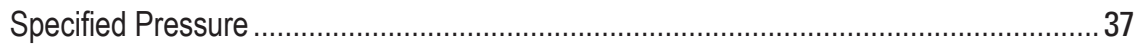

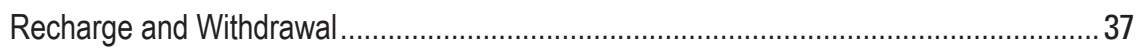

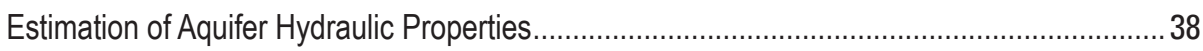

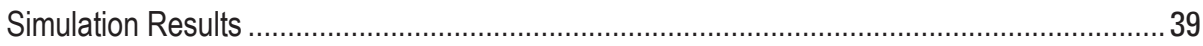

Simulation of Selected Withdrawal and Injection Scenarios........................................................... 39

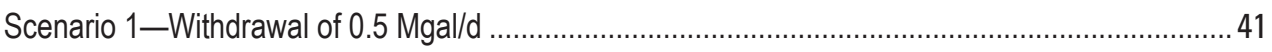

Change in Salinity of Damselfly Anchialine-Pool Habitat in KAHO ....................................... 44

Change of Freshwater Discharge Through KAHO ........................................................ 44

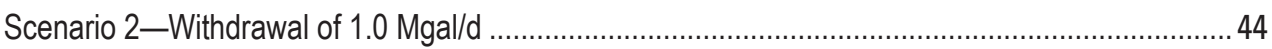

Change in Salinity of Damselfly Anchialine-Pool Habitat in KAHO ......................................... 44

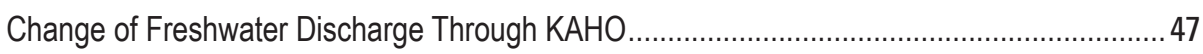

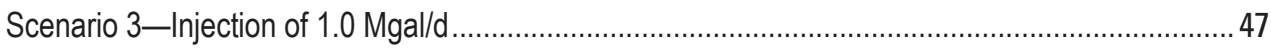

Change in Salinity of Damselfly Anchialine-Pool Habitat in KAHO ……............................... 47

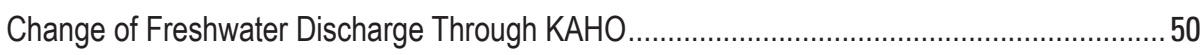

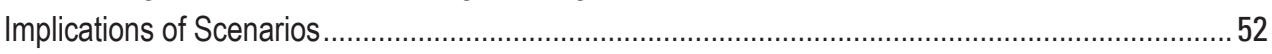

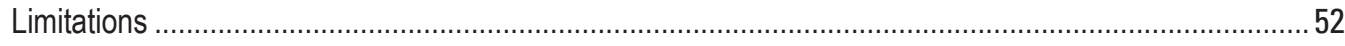

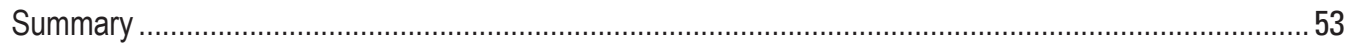

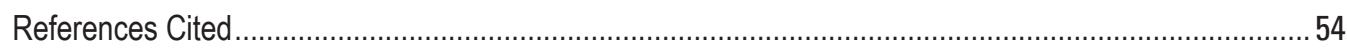

\section{Figures}

1. Map of the island of Hawai'i, Hawai' i, showing Kaloko-Honokōhau National Historical Park within the Keauhou aquifer system and other selected geographic features............................2

2. Map of Kaloko-Honokōhau National Historical Park showing wells, fishponds, and anchialine pools in and near the park, island of Hawai'i, Hawai'i .......................................................... 3

3. Map of the island of Hawai'i, Hawai' i, showing generalized surficial geology and geologic

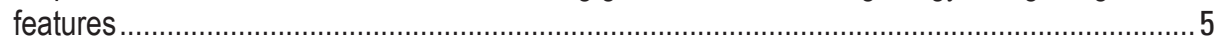

4. Map of the island of Hawai' i, Hawai'i, showing mean annual rainfall distribution during 1978-2007.

5. Line graph showing ocean temperature profiles offshore from the Keauhou area, western Hawai'i and from ALOHA station 1 offshore from O'ahu, Hawai'i .....

6. Diagram showing conceptual models of groundwater occurrence in the Keauhou aquifer system, island of Hawai'i, Hawai'i.

7. Map showing the approximate boundary between coastal freshwater-lens system and inland high water-level area in the Keauhou aquifer system and wells, island of Hawai'i, Hawai'i ...... 12

8. Map showing mean annual recharge distribution for 1984-2008 in the Kona area, island of Hawai'i, Hawai'i. 
9. Map showing tidal efficiency during 2009-10, estimated from groundwater levels recorded in selected wells and anchialine pools in the Keauhou aquifer system, island of Hawai'i, Hawai'i

10. Map showing the daily average groundwater levels on August 7, 2009; May 18 and October 2, 2009; and April 18, 2009 in selected wells and anchialine pools in the Keauhou aquifer system, island of Hawai'i, Hawai'i. .

11. Map showing magnitude and direction of estimated average hydraulic gradient during the period from September 21 to October 20, 2009.

12. Line graph showing fluid specific-conductance profiles from wells in the Keauhou area, Hawai'i

13. Schematic cross sections showing possible geologic structures that may impound groundwater to high levels in the inland part of the Keauhou area, Hawai'i.

14. Graph showing groundwater withdrawals during the period 1970 through 2016 in the State Keauhou aquifer system, Hawai'i.

15. Vertical cross section of the two-dimensional model mesh that represents the area near Kaloko-Honokōhau National Historical Park, Hawaíi

16. Line graphs showing observed, simulated, and sensitivity-analysis salinity and temperature profiles for the Kamakana well 3959-01, Hawai' $\mathrm{i}$

17. Line graph showing observed and simulated transient groundwater levels for selected wells in, and inland from, Kaloko-Honokōhau National Historical Park, Hawai'i..

18. Map showing top view of three-dimensional model mesh, zones, and boundary conditions in the Keauhou area, Hawai'i.

19. Vertical cross section of the three-dimensional model mesh on the south boundary of the model domain, Hawai'i

20. Map showing observed and simulated water levels in the Keauhou area, Hawai'i ...................40

21. Line graph showing observed and simulated salinity profiles for selected wells, Hawai'i.......... 41

22. Map of the Keauhou area, Hawaili, showing the location of sites where salinity samples were collected, and scatterplot showing observed and simulated salinity values.

23. Map showing simulated increase in salinity, caused by the withdrawal of an additional 0.5 million gallons per day from the coastal freshwater-lens system, at the anchialine-pool habitat for the orangeblack Hawaiian damselfly in Kaloko-Honokōhau National Historical Park, Hawai'i.

24. Map showing simulated reduction in the freshwater component of groundwater discharge through Kaloko-Honokōhau National Historical Park caused by the withdrawal of an additional 0.5 million gallons per day from the coastal freshwater-lens system, Hawai'i

25. Map showing simulated increase in salinity, caused by the withdrawal of an additional 1.0 million gallons per day from the coastal freshwater-lens system, at anchialine-pool habitat for the orangeblack Hawaiian damselfly in Kaloko-Honokōhau National Historical Park, Hawai'i.

26. Map showing simulated reduction in the freshwater component of groundwater discharge through Kaloko-Honokōhau National Historical Park caused by the withdrawal of an additional 1.0 million gallons per day from the coastal freshwater-lens system, Hawai'i

27. Map showing simulated change in salinity, caused by the injection of an additional 1.0 million gallons per day of high-salinity water into the coastal freshwater-lens system, at anchialine-pool habitat for the orangeblack Hawaiian damselfly in KalokoHonokōhau National Historical Park, Hawai'i.

28. Map showing simulated reduction in the freshwater component of groundwater discharge through Kaloko-Honokōhau National Historical Park caused by the injection of an additional 1.0 million gallons per day of high-salinity water into the coastal freshwater-lens system, Hawaili 


\section{Tables}

1. Estimated tidal efficiencies from groundwater-level records at selected wells and anchialine pools and corresponding analysis periods, Keauhou area, Hawai' $i$

2. Withdrawal rates and values of top and bottom altitudes assigned to wells represented in the three-dimensional numerical groundwater model, Keauhou area, Hawai'i

\section{Conversion Factors}

U.S. customary units to International System of Units

\begin{tabular}{|c|c|c|}
\hline Multiply & By & To obtain \\
\hline \multicolumn{3}{|c|}{ Length } \\
\hline inch (in.) & 2.54 & centimeter $(\mathrm{cm})$ \\
\hline inch (in.) & 25.4 & millimeter $(\mathrm{mm})$ \\
\hline foot $(\mathrm{ft})$ & 0.3048 & meter $(\mathrm{m})$ \\
\hline mile (mi) & 1.609 & kilometer (km) \\
\hline \multicolumn{3}{|c|}{ Area } \\
\hline square foot $\left(\mathrm{ft}^{2}\right)$ & 0.09290 & square meter $\left(\mathrm{m}^{2}\right)$ \\
\hline square mile $\left(\mathrm{mi}^{2}\right)$ & 259.0 & hectare (ha) \\
\hline square mile $\left(\mathrm{mi}^{2}\right)$ & 2.590 & square kilometer $\left(\mathrm{km}^{2}\right)$ \\
\hline \multicolumn{3}{|c|}{ Volume } \\
\hline gallon (gal) & 3.785 & liter (L) \\
\hline gallon (gal) & 0.003785 & cubic meter $\left(\mathrm{m}^{3}\right)$ \\
\hline million gallons (Mgal) & 3,785 & cubic meter $\left(\mathrm{m}^{3}\right)$ \\
\hline cubic foot $\left(\mathrm{ft}^{3}\right)$ & 0.02832 & cubic meter $\left(\mathrm{m}^{3}\right)$ \\
\hline \multicolumn{3}{|c|}{ Flow rate } \\
\hline foot per second (ft/s) & 0.3048 & meter per second $(\mathrm{m} / \mathrm{s})$ \\
\hline foot per day (ft/d) & 0.3048 & meter per day $(\mathrm{m} / \mathrm{d})$ \\
\hline foot per year (ft/yr) & 0.3048 & meter per year (m/yr) \\
\hline gallon per day (gal/d) & 0.003785 & cubic meter per day $\left(\mathrm{m}^{3} / \mathrm{d}\right)$ \\
\hline million gallons per day (Mgal/d) & 0.04381 & cubic meter per second $\left(\mathrm{m}^{3} / \mathrm{s}\right)$ \\
\hline inch per year (in/yr) & 25.4 & millimeter per year $(\mathrm{mm} / \mathrm{yr})$ \\
\hline \multicolumn{3}{|c|}{ Mass } \\
\hline ounce, avoirdupois (oz) & 28.35 & $\operatorname{gram}(\mathrm{g})$ \\
\hline pound, avoirdupois (lb) & 0.4536 & kilogram (kg) \\
\hline \multicolumn{3}{|c|}{ Pressure } \\
\hline atmosphere, standard (atm) & 101.3 & kilopascal $(\mathrm{kPa})$ \\
\hline bar & 100 & kilopascal (kPa) \\
\hline $\begin{array}{l}\text { pound-force per square inch (lbf/ } \\
\left.\text { in }^{2}\right)\end{array}$ & 6.895 & kilopascal $(\mathrm{kPa})$ \\
\hline pound per square foot $\left(\mathrm{lb} / \mathrm{ft}^{2}\right)$ & 0.04788 & kilopascal $(\mathrm{kPa})$ \\
\hline pound per square inch $\left(\mathrm{lb} / \mathrm{in}^{2}\right)$ & 6.895 & kilopascal $(\mathrm{kPa})$ \\
\hline
\end{tabular}




\section{Conversion Factors-Continued}

\begin{tabular}{|c|c|c|}
\hline Multiply & By & To obtain \\
\hline \multicolumn{3}{|c|}{ Density } \\
\hline pound per cubic foot $\left(\mathrm{lb} / \mathrm{ft}^{3}\right)$ & 16.02 & kilogram per cubic meter $\left(\mathrm{kg} / \mathrm{m}^{3}\right)$ \\
\hline \multicolumn{3}{|c|}{ Hydraulic conductivity } \\
\hline foot per day $(\mathrm{ft} / \mathrm{d})$ & 0.3048 & meter per day $(\mathrm{m} / \mathrm{d})$ \\
\hline \multicolumn{3}{|c|}{ Hydraulic gradient } \\
\hline foot per mile ( $\mathrm{ft} / \mathrm{mi})$ & 0.1894 & meter per kilometer $(\mathrm{m} / \mathrm{km})$ \\
\hline
\end{tabular}

Temperature in degrees Celsius $\left({ }^{\circ} \mathrm{C}\right)$ may be converted to degrees Fahrenheit $\left({ }^{\circ} \mathrm{F}\right)$ as follows:

$$
{ }^{\circ} \mathrm{F}=\left(1.8 \times{ }^{\circ} \mathrm{C}\right)+32 .
$$

Temperature in degrees Fahrenheit $\left({ }^{\circ} \mathrm{F}\right)$ may be converted to degrees Celsius $\left({ }^{\circ} \mathrm{C}\right)$ as follows:

$$
{ }^{\circ} \mathrm{C}=\left({ }^{\circ} \mathrm{F}-32\right) / 1.8 \text {. }
$$

\section{Datum}

Vertical coordinate information is referenced to local mean sea level.

Horizontal coordinate information is referenced to the North American Datum of 1983 (NAD 83).

Altitude, as used in this report, refers to distance above the vertical datum.

\section{Supplemental Information}

Specific conductance is given in microsiemens per centimeter at 25 degrees Celsius $\left(\mu \mathrm{S} / \mathrm{cm}\right.$ at $\left.25^{\circ} \mathrm{C}\right)$. Concentrations of chemical constituents in water are given in either milligrams per liter (mg/L) or micrograms per liter $(\mu \mathrm{g} / \mathrm{L})$.

\section{Abbreviations}

$\begin{array}{ll}\text { CTD } & \text { conductivity-temperature-depth } \\ \text { CWRM } & \text { Hawai'i Commission on Water Resource Management } \\ \text { EPA } & \text { U.S. Environmental Protection Agency } \\ \text { KAHO } & \text { Kaloko-Honokōhau National Historical Park } \\ \text { NELHA } & \text { Natural Energy Laboratory of Hawaii Authority } \\ \text { NPS } & \text { National Park Service } \\ \text { USGS } & \text { U.S. Geological Survey }\end{array}$




\title{
Numerical Simulation of the Effects of Groundwater Withdrawal and Injection of High-Salinity Water on Salinity and Groundwater Discharge, Kaloko- Honokōhau National Historical Park, Hawai'i
}

\author{
By Delwyn S. Oki
}

\section{Abstract}

Kaloko-Honokōhau National Historical Park (KAHO)

is located on the west coast of the island of Hawai' $i$ and contains water resources exposed in fishponds, anchialine pools, and marine waters that are cultural resources and that provide habitat for threatened, endangered, and other culturally important native species. KAHO's water resources are sustained by and dependent on groundwater discharge. In 1978, the year of KAHO authorization, the lands immediately surrounding KAHO were undeveloped and zoned for conservation purposes; at present, most surrounding lands are either developed or zoned for industrial, commercial, or residential use. Urbanization of the North Kona District has increased the need for additional drinking and nonpotable (irrigation) water. Because KAHO's water resources may be affected by existing and proposed groundwater withdrawals and injections of high-salinity water in the surrounding area, the U.S. Geological Survey, in cooperation with the National Park Service, undertook this study to refine the understanding of how groundwater withdrawals and injection of high-salinity water may affect KAHO's water resources.

Changes in KAHO water resources, in terms of changes in salinity and groundwater discharge, were modeled for selected scenarios of groundwater withdrawal and highsalinity water injection in the aquifer. The numerical model was developed using the model code SUTRA, which accounts for density-dependent flow and salinity transport, and included the coastal-confined groundwater system beneath the coastal freshwater-lens system. Model results indicate that withdrawal of additional groundwater from the coastal freshwater-lens system will affect the salinity of KAHO's anchialine pools, which provide habitat for the endangered orangeblack Hawaiian damselfly (Megalagrion xanthomelas). The magnitude of the effect is dependent on the amount and location of the withdrawal. Greater withdrawal rates cause greater increases in salinity in $\mathrm{KAHO}$, other factors being equal. For a given withdrawal rate, the greatest increase in salinity in KAHO is associated with wells withdrawing groundwater in an area inland of KAHO and the least increase in salinity is associated with wells near the coast.
Model results also indicate that withdrawal of additional groundwater from the coastal freshwater-lens system will affect the groundwater discharge, in terms of the freshwater component (water with zero salinity) of the discharge, through KAHO. Greater withdrawal rates cause greater reductions in freshwater discharge through KAHO. For a given withdrawal rate, the greatest reduction in freshwater discharge through $\mathrm{KAHO}$ is associated with wells near the north boundary of $\mathrm{KAHO}$ and the least reduction is associated with wells near the coast to the north and south of KAHO.

Injection of high-salinity water that is denser than ocean water can affect the salinity of damselfly habitat in KAHO, with the magnitude of the effect dependent on the location of the injection. Model results indicate that salinity may either increase or decrease in the anchialine pools that provide damselfly habitat in $\mathrm{KAHO}$, depending on the site of injection. Injection inland of KAHO and at sites immediately north and south of KAHO causes a simulated decrease in salinity at the damselfly habitat, whereas injection farther north and south of KAHO causes an increase in salinity. Injection of high-salinity water also causes a reduction in freshwater discharge through $\mathrm{KAHO}$, with the greatest reduction associated with distant injection wells to the north and south of KAHO and the least reduction associated with wells located near and immediately inland from KAHO.

The numerical groundwater models developed for this study have a number of limitations. Lack of understanding of the subsurface geology constrains the ability to accurately model the groundwater-flow system. The models developed for this study are nonunique, cannot account for local-scale heterogeneities in the aquifer, and contain uncertainties related to recharge, boundary conditions, assigned parameter values in the model, and representations of the different hydrogeological features. Confidence in model results can be improved by addressing these and other limitations. In spite of these limitations, the three-dimensional numerical model developed for this study provides a useful conceptual understanding of the potential effects of additional withdrawals and injections on groundwater resources in KAHO. Further evaluation of the ecologic effects of the simulated changes in groundwater quality and quantity in KAHO is needed but is beyond the scope of this study. 


\section{Introduction}

Kaloko-Honokōhau National Historical Park (KAHO), established in 1978, is located on the west coast of the island of Hawai' $i$, about 3 miles (mi) north of the town of Kailua Kona and within the Keauhou aquifer system, as defined by the Hawai' $i$ Commission on Water Resource Management (CWRM) (fig. 1). KAHO was established by the Federal government to provide a center to preserve, interpret, and perpetuate traditional Native Hawaiian activities and culture, to demonstrate historical land-use patterns, and to provide a resource for the education, enjoyment, and appreciation of traditional Native Hawaiian activities and culture (Public Law 95-625, section 505, November 10, 1978).

The waters in KAHO represent an important resource that made it possible for Native Hawaiians to settle in the arid area. KAHO contains two large traditional Hawaiian fishponds (Kaloko and 'Aimakapā fishponds) with large associated wetlands, more than 180 known anchialine pools, and more than 600 acres of marine waters (fig. 2). Each of these water bodies

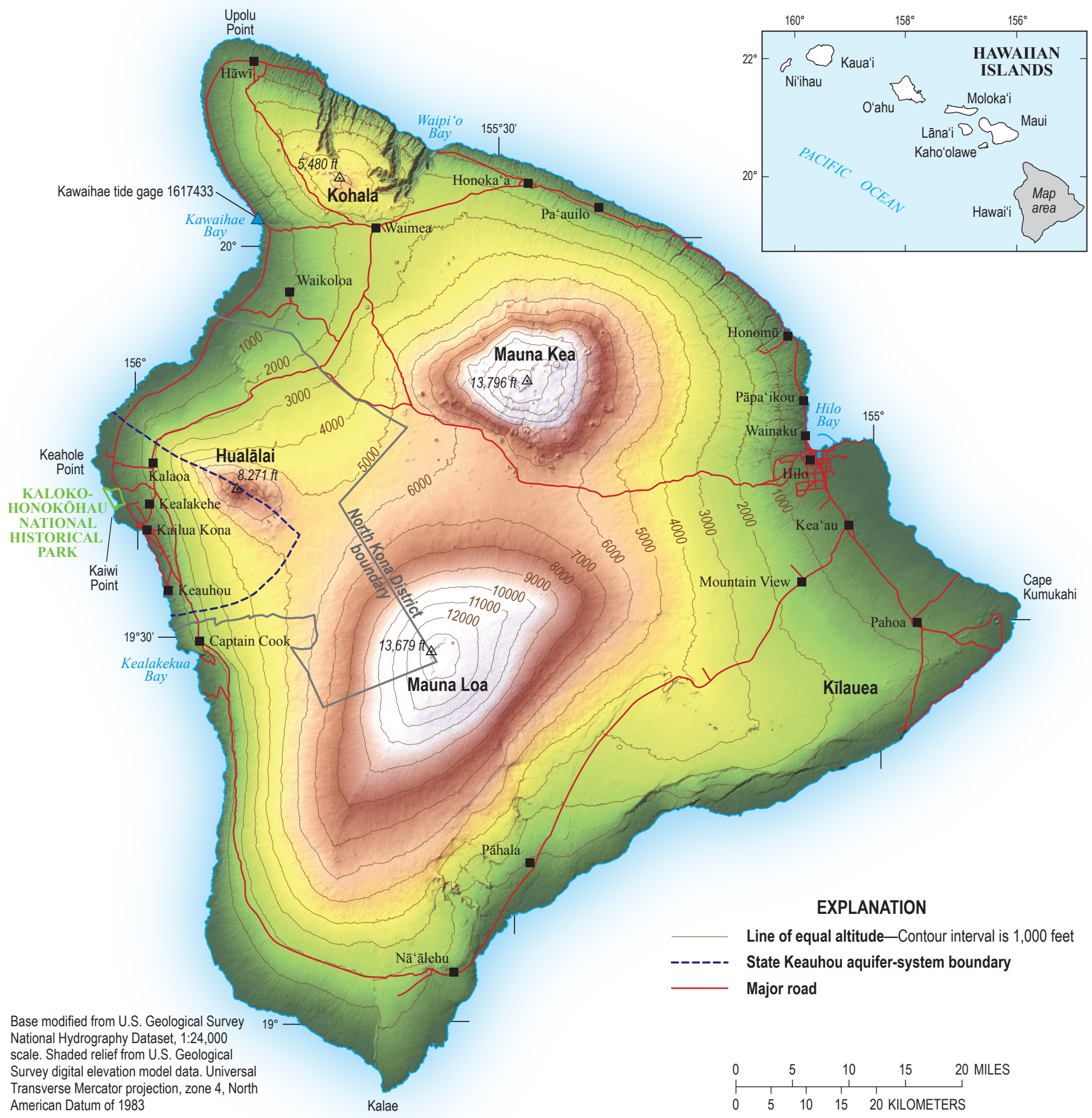

Figure 1. Map of the island of Hawai'i, Hawai'i, showing Kaloko-Honokōhau National Historical Park within the Keauhou aquifer system and other selected geographic features. Color shading added to the map to enhance perception of topography indicated by the altitude contours. 


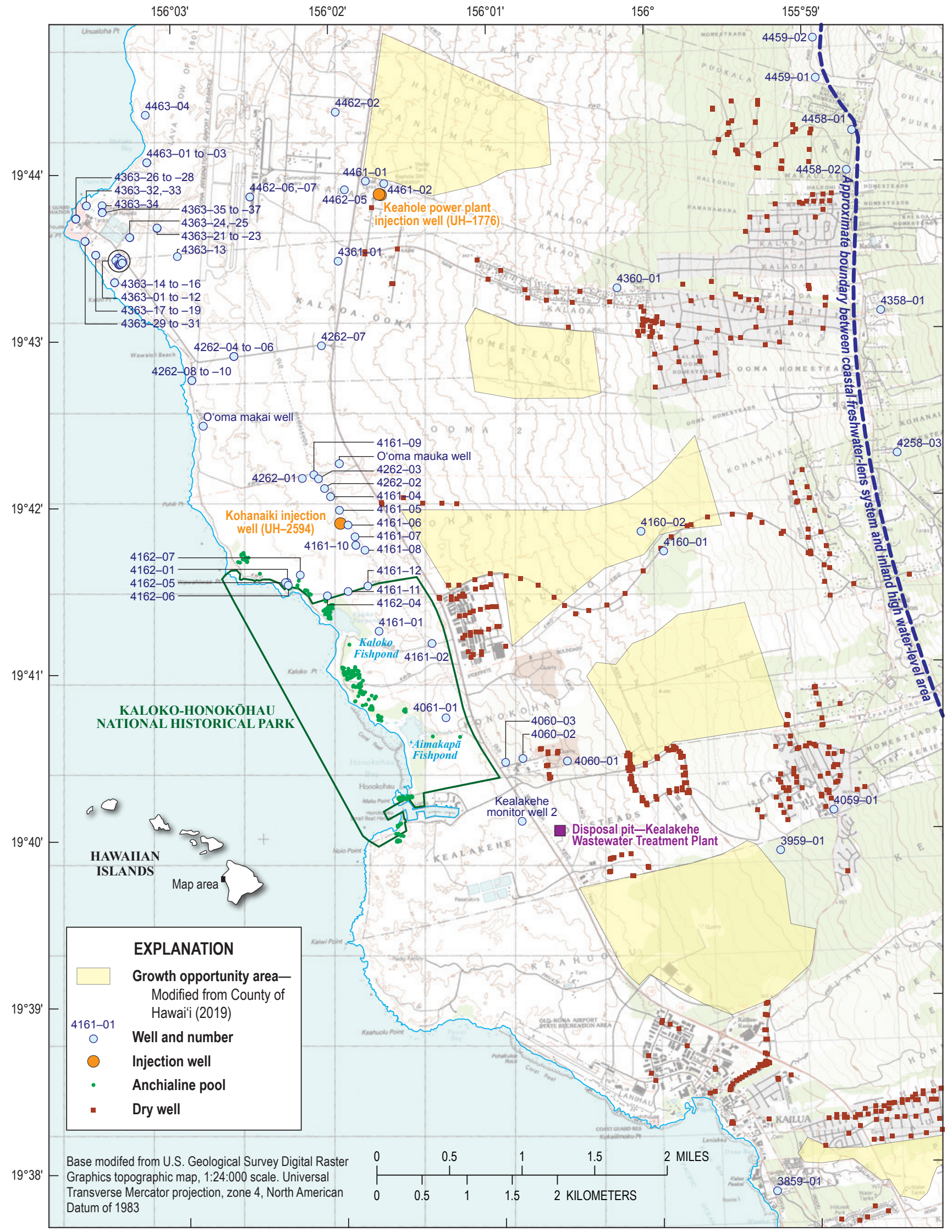

Figure 2. Map of Kaloko-Honokōhau National Historical Park showing wells, fishponds, and anchialine pools in and near the park, island of Hawai'i, Hawai'i. 
is a cultural resource and also provides habitat for threatened, endangered, and other culturally important native species. Kaloko fishpond is located near the northern part of KAHO, has an area of about 11.5 acres, and has a restored rock seawall forming its coastal boundary; 'Aimakapā fishpond is located near the southern part of KAHO, has an area of about 12 acres, and has a sand berm forming its coastal boundary. Native Hawaiians traditionally maintained the fishponds for cultivation of edible fish. The wetlands and fishponds are nesting and feeding habitat for two species of endangered waterbirds, the Hawaiian coot (Fulica americana alai Peale, 1848) and the Hawaiian stilt (Himantopus mexicanus knudseni), and represent a substantial fraction of the available waterbird and shorebird habitat on the island of Hawai' $i$. KAHO's water resources are sustained by, and in the case of the anchialine pools and 'Aimakapā fishpond are mainly dependent on, groundwater discharge for freshwater input. Anchialine pools are rare brackish-water ecosystems that lack a surface connection to the ocean and are hydrologically connected to groundwater and the ocean through a permeable aquifer (Holthuis, 1973; Brock and Kam, 1997). KAHO contains about 25 percent of the estimated 700 anchialine pools in the State (Mitchell and others, 2005). Hawaiian anchialine pools support rare endemic species, some of which remain undescribed, and two species listed as endangered by the U.S. Fish and Wildlife Service (USFWS): the orangeblack Hawaiian damselfly (Megalagrion xanthomelas) and an anchialine pool shrimp (Procaris hawaiana). Some anchialine pool species prefer a specific range of salinity (Tango, 2010), and salinity preference may be dependent on species and life stage. The anchialine pools in KAHO generally have irregular shapes and depths that vary with ocean tide, and although several are large (surface areas exceeding 300 square feet $\left[\mathrm{ft}^{2}\right]$ ), the majority are small (surface areas less than $100 \mathrm{ft}^{2}$ ) and shallow (less than 1.5-ft deep) (Brock and Kam, 1997). During low-tide conditions, some anchialine pools completely drain. Anchialine pool shrimp can withdraw into rock openings in the aquifer during periods when a pool completely drains, and later reemerge into the pool as the pool fills with water during a rising tide.

The resident population in the North Kona District of western Hawai' $i$ increased from 13,748 in 1980 to 37,875 in 2010, representing an increase of about 175 percent (State of Hawai' $i, 2001,2011)$. In 1978, the year of KAHO authorization, the lands immediately surrounding KAHO were undeveloped and zoned for conservation purposes; at present, most surrounding lands are either developed, or zoned for industrial, commercial, or residential use. Numerous dry wells near $\mathrm{KAHO}$ reflect the need to control surface runoff and protect developed areas from flooding (fig. 2). The urbanization of the North Kona District is increasing the need for additional drinking and nonpotable (irrigation) water. KAHO's water resources may be affected by existing and proposed groundwater withdrawals and injections of high-salinity water in the surrounding area.

In a freshwater-lens system, increased withdrawals (all other factors being equal) will result, in the long term, in a decline in water levels, a rise in the transition zone between freshwater and saltwater, and a reduction of natural groundwater discharge to surface-water bodies. The extent to which water levels decline and the transition zone rises is dependent on factors including the distribution and rates of withdrawals and the hydraulic characteristics of the aquifer system. Oki and others (1999) modeled the effects of groundwater withdrawals on freshwater flow through KAHO relative to average 1978 conditions (the year KAHO was established). Model results indicated that increasing withdrawals, relative to 1978 conditions, by 56.8 million gallons per day (Mgal/d) distributed along the western part of Hawai' $i$ will cause a 47 percent reduction of fresh groundwater discharge through $\mathrm{KAHO}$ and groundwater-level declines of about $0.6 \mathrm{ft}$ (see fig. 6 of Oki and others [1999]). The model developed by Oki and others (1999) did not account for the presence of a recently discovered body of coastal confined groundwater that exists beneath the coastal freshwater-lens system. Furthermore, the model was not capable of simulating water-quality changes caused by anthropogenic factors. Additional study was needed to refine the understanding of how anthropogenic factors, including increased groundwater withdrawals and injection of high-salinity water, may affect KAHO's water resources.

\section{Purpose and Scope}

The purpose of this report is to provide information related to how anthropogenic factors may affect water resources in Kaloko-Honokōhau National Historical Park. Specifically, this report presents estimates of changes in salinity and groundwater discharge in KAHO caused by selected scenarios of groundwater withdrawal and injection of high-salinity water, such as reverse-osmosis concentrate, into the aquifer. To meet the objectives of the study, available hydrologic and geologic data were compiled, additional groundwater-level data were collected, and a numerical groundwater model that accounts for the deep coastal confinedgroundwater system was constructed. Previously published groundwater-recharge estimates were used to construct a numerical, density-dependent groundwater flow and transport model capable of simulating changes in groundwater level, salinity, and discharge caused by anthropogenic factors.

\section{Setting}

The island of Hawai' $i$, the largest of the Hawaiian Islands, has an area of about 4,030 $\mathrm{mi}^{2}$ (Juvik and Juvik, 1998) between latitude $18^{\circ} 54^{\prime}-20^{\circ} 17^{\prime} \mathrm{N}$. and longitude $156^{\circ} 04^{\prime}-154^{\circ} 48^{\prime} \mathrm{W}$. (fig. 1). The island is formed primarily by the shield-stage volcanic rocks of Mauna Loa and Kîlauea volcanoes and the shield- and postshield-stage volcanic rocks of Kohala, Hualālai, and Mauna Kea volcanoes (fig. 3; Langenheim and Clague, 1987). Much of the western (Kona) part of the island is formed by volcanic rocks from Hualālai and Mauna Loa volcanoes (Stearns and Macdonald, 1946). Although KAHO is the primary area of interest, the larger study area for the modeling analysis is within the Keauhou aquifer system as defined by CWRM. 


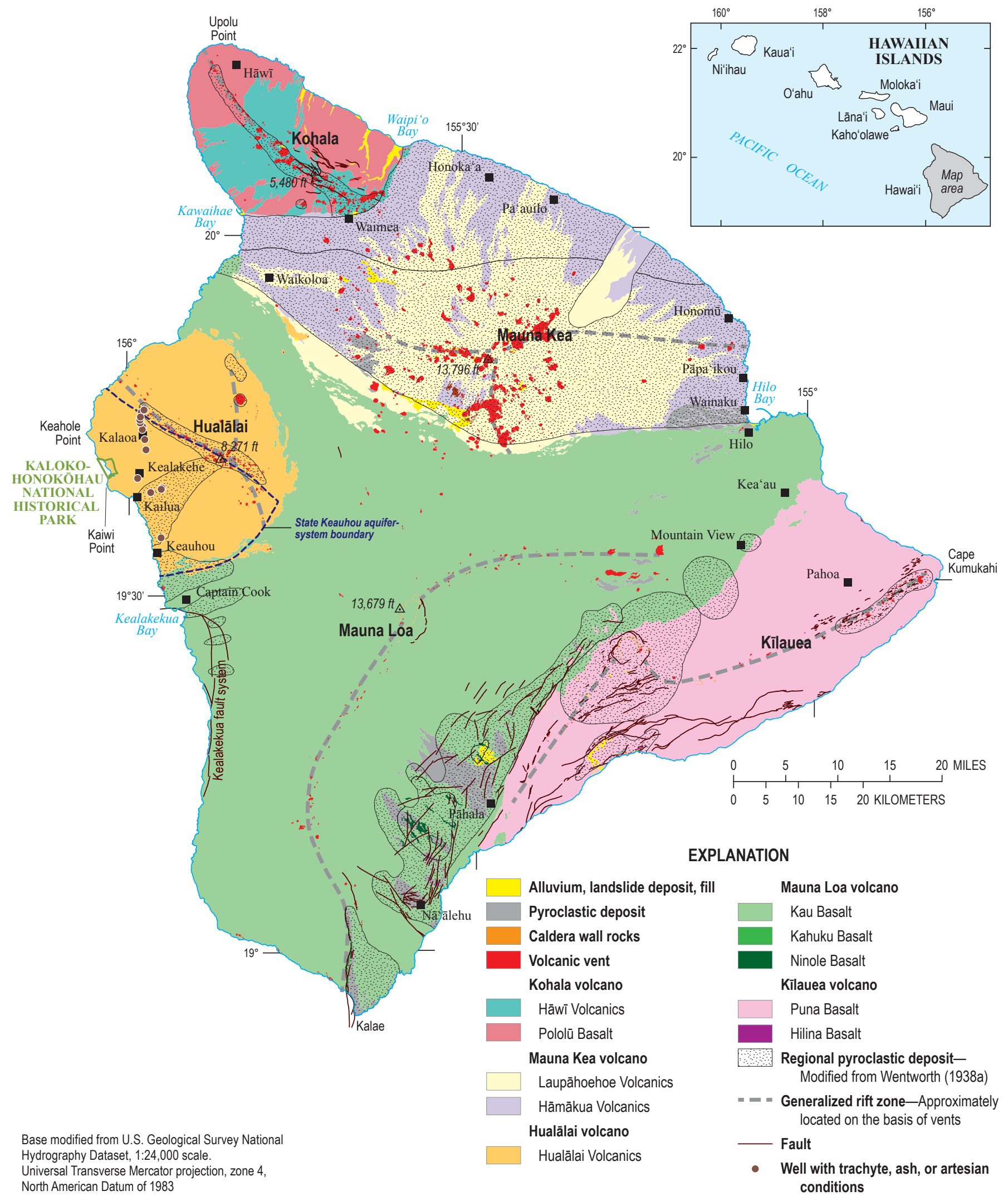

Figure 3. Map of the island of Hawai'i, Hawaíi, showing generalized surficial geology and geologic features (modified from Wentworth, 1938a; Langenheim and Clague, 1987; Sherrod and others, 2007). 
The Keauhou aquifer system is bounded on the northeast by the northwest rift zone of Hualālai volcano (hereafter referred to as Hualālai), on the southeast by the approximate surface contact between volcanic rocks from Hualālai and Mauna Loa, and on the west by the coast. Thus, the Keauhou aquifer system mainly is formed by volcanic rocks from Hualālai (fig. 3). Within the Keauhou aquifer system, landsurface altitudes range from $0 \mathrm{ft}$ at the coast to about $8,271 \mathrm{ft}$ near a volcanic vent within the northwest rift zone of Hualālai. Below an altitude of 1,000 ft, the land-surface slopes range from nearly flat in coastal areas to about 9 degrees near the southern part of the area; between altitudes of 1,000 and $3,000 \mathrm{ft}$, slopes generally range from 6 to 9 degrees; above an altitude of 3,000 ft, slopes commonly exceed 9 degrees but are less than 5 degrees in places, particularly toward the southern part of the Keauhou aquifer system near the saddle between Hualālai and Mauna Loa. KAHO lies on the west flank of Hualālai below an altitude of about $80 \mathrm{ft}$.

\section{Climate}

Near Keahole Point, north of KAHO, computed climate conditions for 1981-2010 (Arguez and others, 2011) indicate an average annual temperature of 77.4 degrees Fahrenheit $\left({ }^{\circ} \mathrm{F}\right.$; 25.2 degrees Celsius $\left.\left[{ }^{\circ} \mathrm{C}\right]\right)$, and average monthly temperatures ranging from $73.8^{\circ} \mathrm{F}\left(23.2^{\circ} \mathrm{C}\right)$ in February to $80.4^{\circ} \mathrm{F}\left(26.9^{\circ} \mathrm{C}\right)$ in August (National Climatic Data Center, 2013b). During 1981-2010, minimum monthly temperatures near Keahole Point have dropped below $65^{\circ} \mathrm{F}\left(18.3^{\circ} \mathrm{C}\right)$ and maximum monthly temperatures commonly exceeded $85^{\circ} \mathrm{F}\left(29.4^{\circ} \mathrm{C}\right)$ (National Climatic Data Center, 2013a). Below an altitude of 3,900 ft, the average temperature lapse rate in Hawai' $\mathrm{i}$ is estimated to be $3.6^{\circ} \mathrm{F}$ per $1,000 \mathrm{ft}$, and above an altitude of $3,900 \mathrm{ft}$, the average temperature lapse rate decreases to $3{ }^{\circ} \mathrm{F}$ per 1,000 ft (Nullet and Sanderson, 1993).

Climate within the Keauhou aquifer system is very diverse. Using the Koeppen classification, which is based mainly on temperature, climate is classified as hot semi-arid desert near the coast (including KAHO); humid tropical (continuously wet) between altitudes of about 1,000 and 3,000 ft; and temperate (continuously wet warm temperature) above an altitude of 3,000 ft (Juvik and others, 1978). Using the Thornthwaite climatic classification, which considers the relation between precipitation and potential evapotranspiration, climate is classified mainly as subhumid to semiarid, except between altitudes of about 1,000 and 3,000 $\mathrm{ft}$ where climate is classified as humid (Giambelluca and Sanderson, 1993).

Rainfall in the Kona area is affected by topography and ocean-land temperature and pressure gradients related to heating of the west-facing slopes of Hualālai and Mauna Loa. In the Kona area, heating of the land surface during the day generates sea breezes that may converge with the trade winds diverted around the high volcanoes, producing a zone of convergence on west-facing slopes (Giambelluca and others, 1986). The sea breezes bring moisture-laden air from offshore to the mountain slopes, commonly resulting in precipitation in the afternoon hours. In the Kona area, rainfall is greater during the summer months (May through October), characterized by more intense heating and persistent trade winds, than during the winter months (November through April). This seasonal pattern of rainfall in the Kona area differs from other areas in Hawai'i (particularly dry areas), which have greater rainfall during the winter months.

Mean annual rainfall for the period 1978-2007 in the Keauhou aquifer system was less than 15 inches (in.) at the coast near the northwest boundary, between 15 and 25 in. within $\mathrm{KAHO}$, greater than 50 in. between altitudes of about 1,000 and 3,000 ft, and less than 35 in. above an altitude of 5,000 ft (fig. 4) (Giambelluca and others, 2013).

\section{Geology}

The overall geology of Hawai'i has been described by numerous investigators (for example, Stearns and Macdonald, 1946; Macdonald and others, 1983; Stearns, 1985). Langenheim and Clague (1987) described and renamed the stratigraphic framework of volcanic rocks on Hawai'i. Volcanic rocks from Hualālai mainly are relevant to this study.

\section{Extrusive Volcanic Rocks}

Hualālai is one of five volcanoes that form the island of Hawai'i (fig. 3) and is inferred to have started forming about 800,000 years ago (800 ka; Moore and others, 1987; Moore and Clague, 1992; Yamasaki and others, 2009). The summit of Hualālai, at an altitude of $8,271 \mathrm{ft}$, is about $10 \mathrm{mi}$ east of KAHO. Extrusive volcanic rocks cover the surface of Hualālai and consist mainly of lava flows that effused from fissures and vents. Extrusive volcanic rocks also include pyroclastic material, such as ash and cinder, which generally forms less than 1 percent of the mass of Hawaiian volcanoes (Wentworth and Macdonald, 1953).

The southeastern part of Hualālai is covered by younger lava flows from Mauna Loa volcano (Lipman and Coombs, 2006). About 55 percent of the volcanic rocks on the surface of Hualālai are less than 3,000 years old (Moore and others, 1987). The most recent flow from Hualālai is an 1801 flow north of KAHO that destroyed villages and filled coastal fishponds (Kauahikaua and Camara, 2000). Surface volcanic rocks in KAHO are 10,000-1,500 years old (Wolfe and Morris, 1996).

Shield-stage tholeiitic basalt built most of Hualālai but is not exposed on the land surface. Tholeiitic rocks have been recovered from dredges and submersible dives (Clague, 1982; Moore and Clague, 1987, 1992; Garcia and others, 1989; Clague and Moore, 1991; Lipman and Coombs, 2006; Hammer and others, 2006; Yamasaki and others, 2009) and from drilled wells (Moore and others, 1987; Clague, 1987). A change in lava chemistry from tholeiitic basalt to trachyte and alkalic basalt about 130 to 100 ka marks the transition from the shield stage to the postshield stage of Hualālai. 
The entire subaerial surface of Hualālai consists of postshield-stage alkalic basalt, with minor hawaiite and trachyte, collectively named the Hualālai Volcanics (Langenheim and Clague, 1987; Wolfe and Morris, 1996). On the flanks of Hualālai, mapped dips of the Hualālai Volcanics typically are about 2 to 15 degrees (Stearns and Macdonald, 1946). Trachyte lavas, which are rare in Hawai' $i$, are exposed at the surface on Hualālai and also have been found in rock

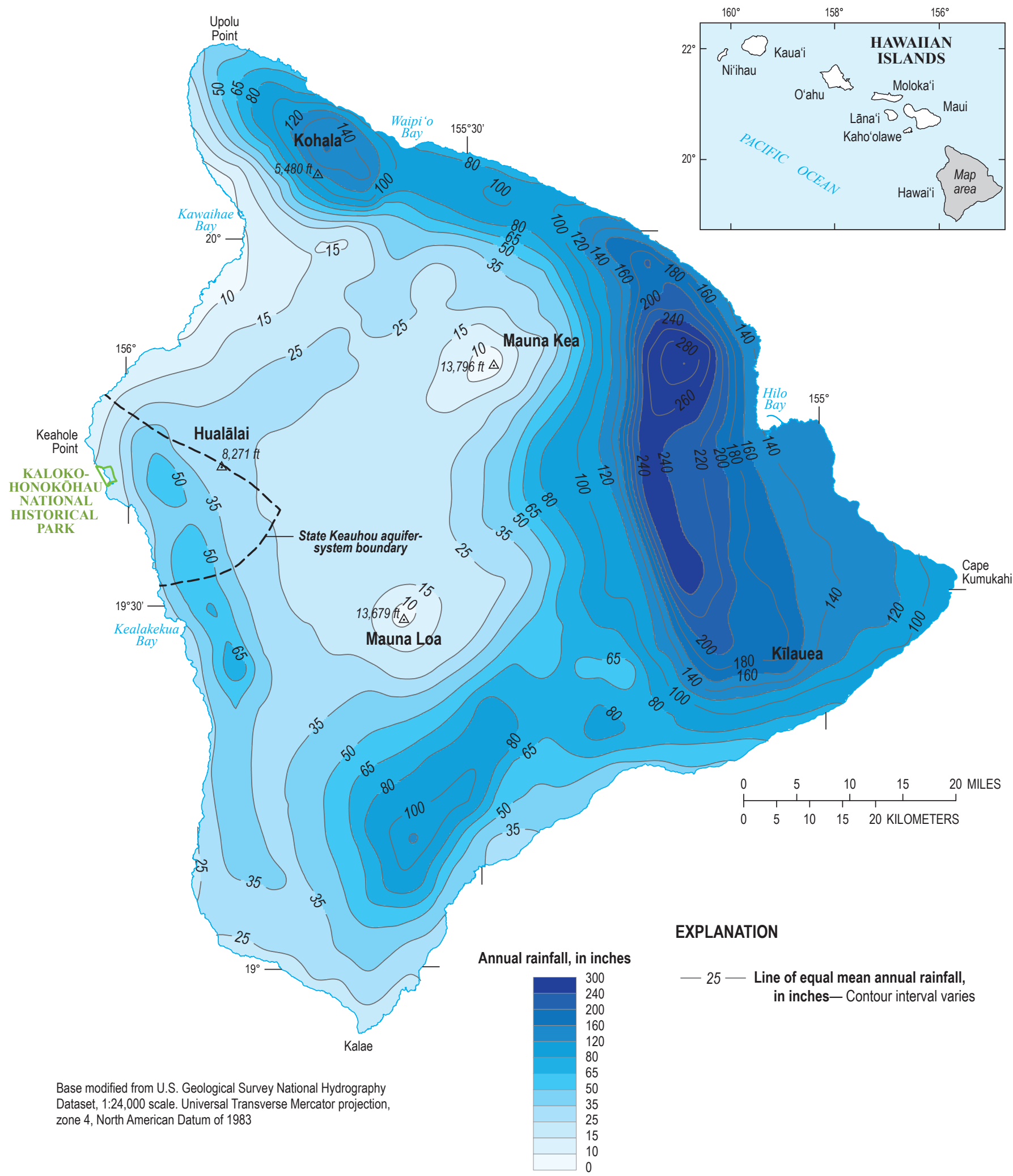

Figure 4. Map of the island of Hawai' i, Hawai' i, showing mean annual rainfall distribution during 1978-2007 (modified from Giambelluca and others, 2013). 
samples from wells drilled into Hualālai (Cousens and others, 2003; Bauer, 2003). Trachyte lavas from Hualālai have estimated ages of about 114-92 ka (Cousens and others, 2003). The shift from trachyte to alkalic basalt eruptions was marked by an increase in eruption rate (Moore and others, 1987; Cousens and others, 2003). Trachyte lavas generally are very viscous and form thick and massive flows. Trachyte lavas may be hydrologically important because they have low permeability and may form confining units that impede groundwater movement.

Pyroclastic deposits consist of fragmental material, including cinder and ash, that originated from volcanic eruptions and were deposited from the air. Pyroclastic deposits vary in fragment size, with coarse material typically deposited closer to the source eruption than fine material. Fine ash deposits composed of material less than 0.08 in. (2 millimeters) in diameter can be widespread and blanket the land surface at large distances from the source eruption. However, wind and rain can erode ash deposits, especially if the deposits are recent and thin. On the island of Hawai' $i$, ash deposits range in thickness from less than $1 \mathrm{ft}$ to greater than $10 \mathrm{ft}$ (Wentworth, 1938a). Volcanic ash can be weathered and consolidated into tuff, which may have low permeability. Laboratory permeability tests of five weathered-ash core samples from $\mathrm{O}$ 'ahu indicated hydraulic-conductivity values ranging from 0.002 to 300 feet per day (ft/d; Wentworth, 1938b).

Wentworth (1938a) mapped tuff deposits over large areas of Hualālai (fig. 3). Tuff deposits in the subsurface can be hydrologically important if they are spatially continuous and widespread by forming low-permeability perching or confining units that impede groundwater flow. A number of wells on Hualālai have penetrated trachyte flows (Bauer, 2003), ash layers, or undescribed low-permeability layers that potentially can form perching or confining units in the subsurface (fig. 3).

\section{Intrusive Volcanic Rocks}

Intrusive volcanic rocks include those rocks, such as dikes, that formed by magma that cooled below the ground surface. Dikes associated with the rift zones of Hualālai are not exposed at the surface, but cinder and spatter cones within the rift zones are evidence of the presence of dikes that are related to the subsurface system of magma supply to these volcanic vents. Dikes are hydrologically important because they have low permeability and, because of their low permeability, tend to impound groundwater behind them to higher levels than would exist in the absence of dikes.

The primary rift zones of Hualālai trend northwest and south-southeast, emanate from near the summit of the volcano, and are marked by numerous cinder and spatter cones. A third, less well-defined rift zone extends north from the summit (Macdonald and others, 1983; Moore and others, 1987). A positive gravity anomaly exists near, but is somewhat west of, the surface expression of the south-southeast rift zone of the volcano (Kinoshita and others, 1963; Kinoshita, 1965; Kauahikaua and others, 2000; Flinders and others, 2013). Zucca and others (1982) analyzed gravity and seismic- refraction data and indicated that a dense structure with high seismic velocity lies parallel to the Kona coast in the vicinity of the positive gravity anomaly and probably represents a buried rift zone. The buried rift may extend south of surface exposures of Hualālai volcanic rocks (Lipman and Coombs, 2006). On the basis of the presence of an intervening gravity saddle, Lipman and Coombs (2006) indicated that this buried Hualālai rift probably does not merge with the south rift zone of Mauna Loa, as interpreted by Holcomb and others (2000).

\section{Sedimentary Deposits}

Within the study area, terrestrial sedimentary deposits on the relatively youthful subaerial surface of Hualālai are limited. Thin calcareous sand and gravel deposits form beaches and overlie volcanic rocks in coastal areas, particularly in the northern part of the study area, including KAHO (see for example, Richmond and others, 2008). Marine sedimentary deposits associated with coral reefs generally are preserved only after a volcano has completed its shield-building stage because the high frequency of lava flows tends to inhibit reef development (Moore and Clague, 1992). Hualālai is in the post-shield stage and coral reefs have developed offshore in places. Coral reefs and sand deposits have been mapped immediately offshore of KAHO lands (Gibbs and others, 2007) and also can be found in coastal areas outside of KAHO. Modern living coral generally is found in depths shallower than about 30 meters (m; Moore and Fornari, 1984). Moore and Clague (1992) describe six submerged reefs north of the study area at depths of about 500 to $4,400 \mathrm{ft}$. The shallowest of these submerged reefs ( $500 \mathrm{ft}$ ) extends for about $60 \mathrm{mi}$ along the west coast of Hawai' $i$, from the northern tip of the island to just south of Kealakekua Bay (Moore and Clague, 1987). This buff-colored, massive coralline limestone reef, which drowned about $13 \mathrm{ka}$, is draped by about 50 lava flows, which in turn have subsequently been covered by additional reef material (Moore and Fornari, 1984; Moore and Clague, 1987). The drowned reef at an altitude of $-500 \mathrm{ft}$ may be correlative with the Kahipa-Mamala $-350-\mathrm{ft}$ shelf off O'ahu (Stearns, 1978; Moore and Fornari, 1984), which would indicate that northwest Hawai' $i$ has subsided about $150 \mathrm{ft}$ relative to $\mathrm{O}^{\prime}$ ahu over the past 13,000 years.

The geologic log of a well drilled about 2 mi southeast of KAHO (well 3959-01, Kamakana) within the study area indicates a calcareous beach sand between altitudes of about $-1,073$ and $-1,088 \mathrm{ft}$ (Bauer, 2011). The depth of the beach sand is between the depths of two drowned reefs $(-500 \mathrm{ft}$ and $-1,400 \mathrm{ft}$, respectively) described by Moore and Clague (1992).

\section{Faults}

Gravitational failure of the unbuttressed submarine west flanks of Hualālai and Mauna Loa produced a large region of landslide deposits, including the North Kona slump and Alika debris avalanches (Lipman and others, 1988; Moore and others, 1989, 1994; Lipman and Coombs, 2006; Cannon and others, 2007). The submerged Mahukona volcano may have buttressed 
the northwestern part of Hualālai volcano and prevented failure of the northwest submarine flanks of Hualālai volcano. Landslide deposits associated with the North Kona slump, downslope of the west flank of Hualālai, are at water depths of about 6,500-15,000 ft (Lipman and Coombs, 2006). The North Kona slump may have crept over an extended period (as opposed to a catastrophic debris avalanche) during the shield stage of Hualālai and is characterized by multiple benches and normal-fault scarps that are a few thousand feet high in places (Moore and Clague, 1992; Moore and others, 1994; Lipman and Coombs, 2006). The original headwall appears to have been buried by younger eruptions and original scarp surfaces commonly are smoothed and modified by draping pillow lavas from the shield stage (Lipman and Coombs, 2006). The submarine slopes of Hualālai, down to a water depth of about $5,000 \mathrm{ft}$, may be mantled with sediment in places (Lipman and Coombs, 2006), although volcanic-rock outcrops without sediment cover also likely exist.

The ocean bathymetry reflects the occurrence of submarine landslides. Between Keahole Point and Kaiwi Point (fig. 3), 1,000-ft water depths generally are within a mile of the coast. In contrast, the $1,000-\mathrm{ft}$ contour on land commonly is more than $3 \mathrm{mi}$ inland from the coast. South of Kaiwi Point, 1,000 -ft water depths commonly are more than $2 \mathrm{mi}$ offshore. Average ocean-bottom slopes generally are less than 5 degrees for water depths shallower than about $300 \mathrm{ft}$, although slopes commonly are greater than 20 degrees between depths of 300 to $3,000 \mathrm{ft}$.
Subaerial evidence of faults near the study area exists near Kealakekua Bay (fig. 3), south of the Keauhou aquifer system. The cliff forming the northeast boundary of Kealakekua Bay is a normal fault at the northern extent of the Kealakekua fault system, which extends about $18 \mathrm{mi}$ south of the bay (Macdonald and others, 1983; Wolfe and Morris, 1996). Lipman and Coombs (2006) indicated that a conspicuous change in lithology exposed on the 600 -ft-high subaerial Kealakekua fault scarp could mark a boundary between tholeiitic lavas from Hualālai and Mauna Loa. The Kealakekua fault, which is at the head of large submarine landslide complexes, has been inactive for about $14,000-18,000$ years as indicated by the existence of an unbroken, submerged reef at the head of the submarine landslides (Moore and others, 1994; Lipman and Coombs, 2006).

\section{Ocean Temperatures}

Because of the steeply sloping ocean bottom near the study area, a source of cold saltwater that can enter the aquifer is available within a short distance from the coast. Ocean temperatures near the study area generally decrease with depth and may vary in space and time in response to changes in ocean currents as well as air temperature. Limited temperature-profile data from near the study area may reflect this variability (fig. 5). Sources of data used to characterize the ocean temperature as a function of depth include (1) an ocean-temperature profile collected by the Hawai' $i$ Undersea

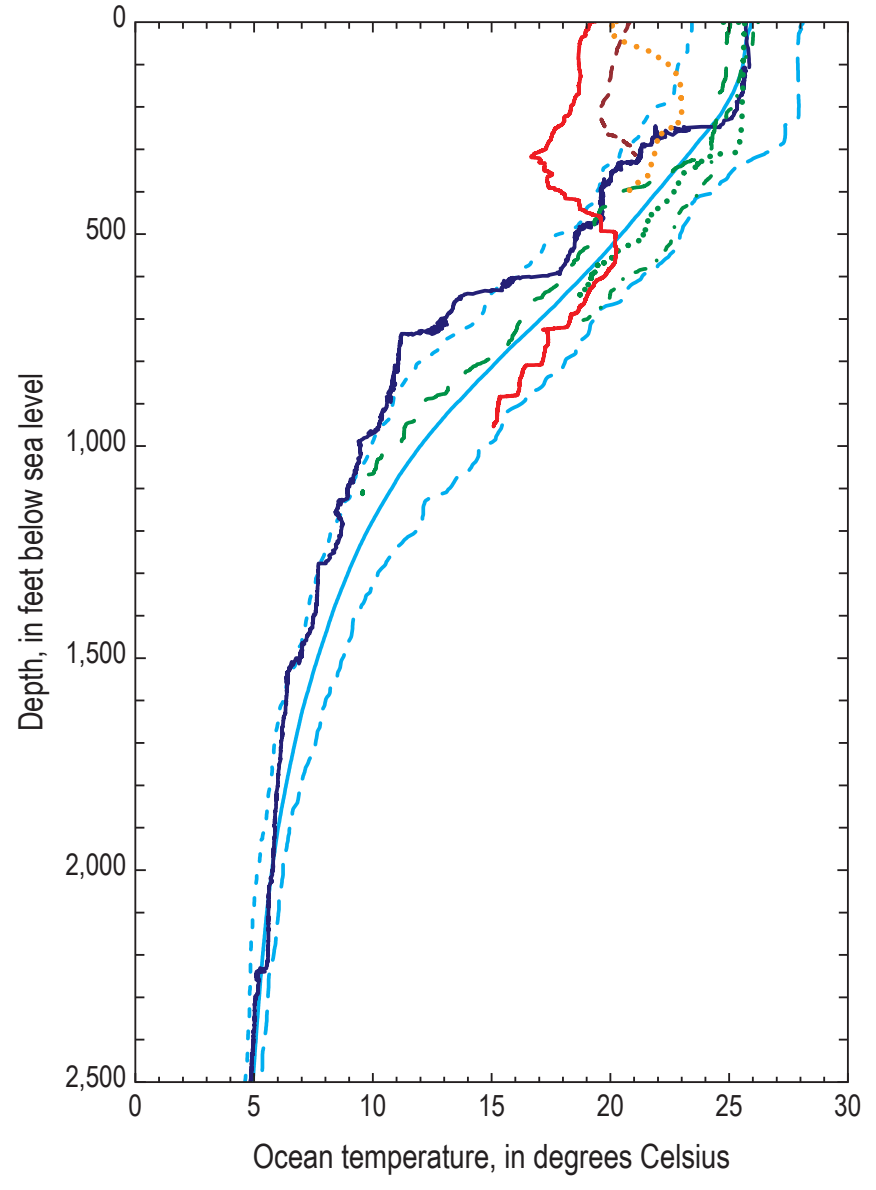

\section{EXPLANATION}

Ocean temperature modified from conductivitytemperature-depth (CTD) logger data collected during Hawai' $i$ Undersea Research Laboratory submersible dive, December 3, 2007-From Keith Olson, Natural Energy Laboratory of Hawai'i Authority, written commun. (2009)

Ocean temperature from boat-deployed CTD cast-From Tom Nance, Tom Nance Water Resource Engineering, written commun. (2012)

-... June 7, 2000

.... November 21, 2011

- _ December 9, 2011

Ocean temperature from station ALOHA profiles collected from December 1, 1988, to November 27, 2011-From Lucas (2013)

- - Maximum

- Average

.... Minimum

- Groundwater temperature from Kamakana well, 3959-01, April 3, 2010-From Tom Nance, Tom Nance Water Resource Engineering, written commun. (2012)

.... Groundwater temperature from Kahalu'u well, 3457-04, May 19, 2009_From Patrick Casey, Hawaili Commission on Water Resource Management, written commun. (2020)

- - - Groundwater temperature from Keahole power plant injection well, UH-1776, July 22, 2003From Tom Nance, Tom Nance Water Resource Engineering, written commun. (2012)
Figure 5. Line graph showing ocean temperature profiles offshore from the Keauhou area, western Hawaili and from ALOHA station 1 offshore from O'ahu, Hawai'i. 
Research Laboratory on December 3, 2007, off Keahole Point using a conductivity-temperature-depth (CTD) logger attached to a manned submersible (Pisces V) during an inspection of a submarine pipeline (Keith Olson, Natural Energy Laboratory of Hawai'i Authority, written commun., 2009); (2) 3 ocean-temperature profiles collected using a CTD logger deployed from a boat off the Kona coast on June 7, 2000, November 21, 2011, and December 9, 2011 (Tom Nance, Tom Nance Water Resource Engineering, written commun., 2012); and (3) 173 ocean-temperature profiles collected with a CTD at ALOHA station 1 (lat $21^{\circ} 20^{\prime}$ N., long $158^{\circ} 16^{\prime}$ W.) off western Oahu between December 1, 1988, and November 27, 2011 (Lucas, 2013). The minimum and maximum temperature profiles measured at ALOHA station 1 generally bracket the profiles collected near the study area, and the average temperature profile from ALOHA station 1 appears to be generally representative of conditions near the study area. From the average temperature profile, the ocean temperature is between about $25^{\circ} \mathrm{C}$ and $26^{\circ} \mathrm{C}$ near the surface (water temperatures hereinafter are reported in units of degrees Celsius, which are most commonly used and which can be readily converted to degrees Fahrenheit using the expression at the bottom of the Conversion Factors table near the front of this report); decreases to $20^{\circ} \mathrm{C}$ at $530 \mathrm{ft}$; decreases to $15^{\circ} \mathrm{C}$ at $815 \mathrm{ft}$; decreases to $10^{\circ} \mathrm{C}$ at $1,175 \mathrm{ft}$; and is less than $5^{\circ} \mathrm{C}$ below a depth of $2,450 \mathrm{ft}$ (fig. 5). Thus, saltwater that is colder than $20^{\circ} \mathrm{C}$ may enter the aquifer below ocean depths of about $500 \mathrm{ft}$.

\section{Groundwater-Flow System}

Precipitation is the main source of fresh groundwater in Hawai' $i$. The precipitation either (1) runs off, (2) evaporates, (3) is transpired by vegetation, or (4) recharges the groundwater system. Fresh or brackish groundwater in western Hawai' $i$ is found in three main forms: (1) as a coastal freshwater-lens system, which consists of an unconfined lensshaped body of freshwater or brackish water floating on denser, underlying saltwater within permeable dike-free volcanic rocks; (2) as a coastal confined-groundwater system beneath the freshwater-lens system; and (3) as water impounded to high levels (greater than about $40 \mathrm{ft}$ above mean sea level) within or inland from areas of lower overall permeability inland of the freshwater-lens system (fig. 6). The hydrologic connection among the three groundwater bodies is not well understood. The boundary between the coastal freshwater-lens system and the inland high water-level area is uncertain but constrained by water-level information from existing wells and is near a land-surface altitude of about 1,500 ft (fig. 7). In general, groundwater levels are highest in the inland areas and lowest near the coast and, thus, groundwater flows from inland areas to coastal discharge areas.

For the purposes of this study, saltwater is assumed to have a dissolved solids concentration of 35.7 grams per kilogram $(\mathrm{g} / \mathrm{kg})$ and a fluid specific conductance of about 53,800 microsiemens per centimeter $(\mu \mathrm{S} / \mathrm{cm})$ at $25^{\circ} \mathrm{C}$; pure freshwater is assumed to have a dissolved solids concentration of zero. From a practical standpoint, however, freshwater commonly is associated with fresh drinking water that generally has a chloride concentration less than 250 milligrams per liter $(\mathrm{mg} / \mathrm{L})$, which is roughly equivalent to water with a dissolved solids concentration less than about $0.45 \mathrm{~g} / \mathrm{kg}$ and a fluid specific conductance less than about $700 \mu \mathrm{S} / \mathrm{cm}$. Brackish water is assumed to be a mixture of freshwater and saltwater and have a dissolved solids concentration between 0.45 and $35.7 \mathrm{~g} / \mathrm{kg}$.

\section{Groundwater Recharge}

Groundwater is recharged by direct infiltration of rainfall over much of the study area. Over some areas, groundwater-recharge rates are low because of low rainfall and high evaporation rates. Recharge from rainfall may be supplemented by fog drip, irrigation, or wastewater discharges. Groundwater recharge in the Keauhou aquifer system was most recently estimated using a daily water budget for the period from 1984 through 2008 (Engott, 2011). Average recharge in the Keauhou aquifer system during the period 1984-2008 was estimated to be about $106 \mathrm{Mgal} / \mathrm{d}$, with about $67 \mathrm{Mgal} / \mathrm{d}$ in the inland high water-level area and $39 \mathrm{Mgal} / \mathrm{d}$ over the coastal freshwater-lens system. Recharge is highest in areas of high rainfall (between altitudes of about 1,000 and 3,000 ft) or in a wastewater disposal pit southeast of KAHO (fig. 8; Engott, 2011).

\section{Coastal Freshwater-Lens System}

The source of freshwater in the coastal freshwater-lens system of western Hawai' $i$ is groundwater recharge from (1) infiltration of rainfall and fog drip, (2) irrigation water, (3) wastewater disposal, and (4) storm runoff captured by dry wells. In addition, upward discharge from the underlying coastal confined groundwater system or discharge from the upgradient high water-level area may contribute to the freshwater component of water in the coastal freshwaterlens system.

Because the dike-free volcanic rocks near the coast are highly permeable and because thick accumulations of lowpermeability sediments have not formed offshore as in other areas of the State (for example, southern $\mathrm{O}^{\prime} \mathrm{ahu}$ ), freshwater can readily discharge to the ocean, saltwater can readily enter the aquifer, groundwater levels are relatively low (generally less than a few feet), and the magnitude of the horizontal hydraulic head gradient is small (less than a foot per mile $[\mathrm{ft} / \mathrm{mi}]$ in some places). The freshwater discharge creates a saltwater-circulation system beneath the freshwater lens (Cooper and others, 1964; Souza and Voss, 1987). Saltwater flows landward in the deeper parts of the aquifer, rises, and then mixes with seaward-flowing freshwater. This mixing creates a brackish-water transition zone. In areas near the coast where saltwater mixes thoroughly with seaward-flowing freshwater, a freshwater lens may not form and brackish water may exist at the water table. 

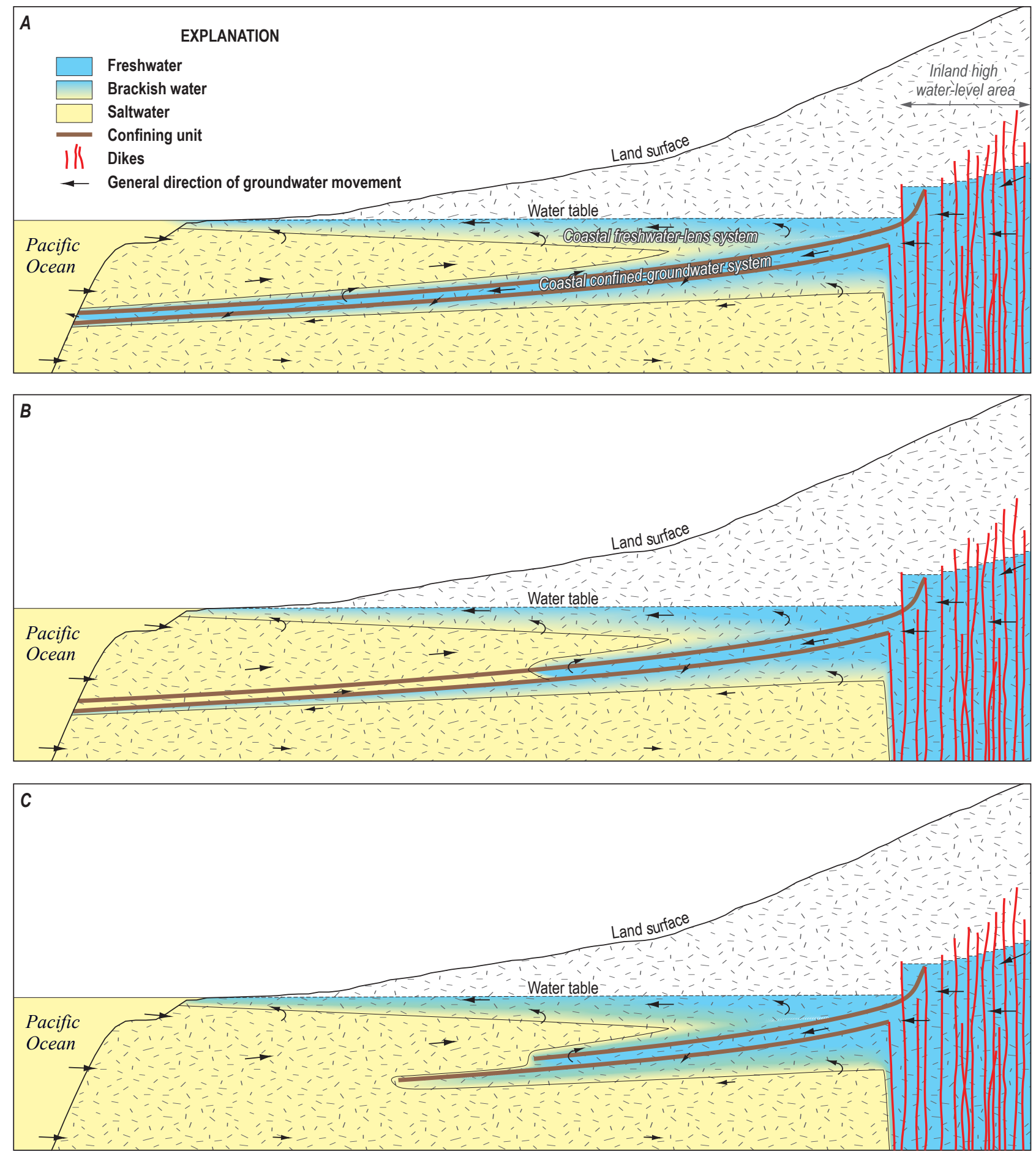

Figure 6. Diagram showing conceptual models of groundwater occurrence in the Keauhou aquifer system, island of Hawai'i, Hawaili, for cases of $A$, coastal confined groundwater discharging directly to ocean; $B$, no coastal confined groundwater discharging directly to ocean even though confining units extend to ocean; and $C$, no coastal confined groundwater discharging directly to ocean because confining units do not extend to ocean. 


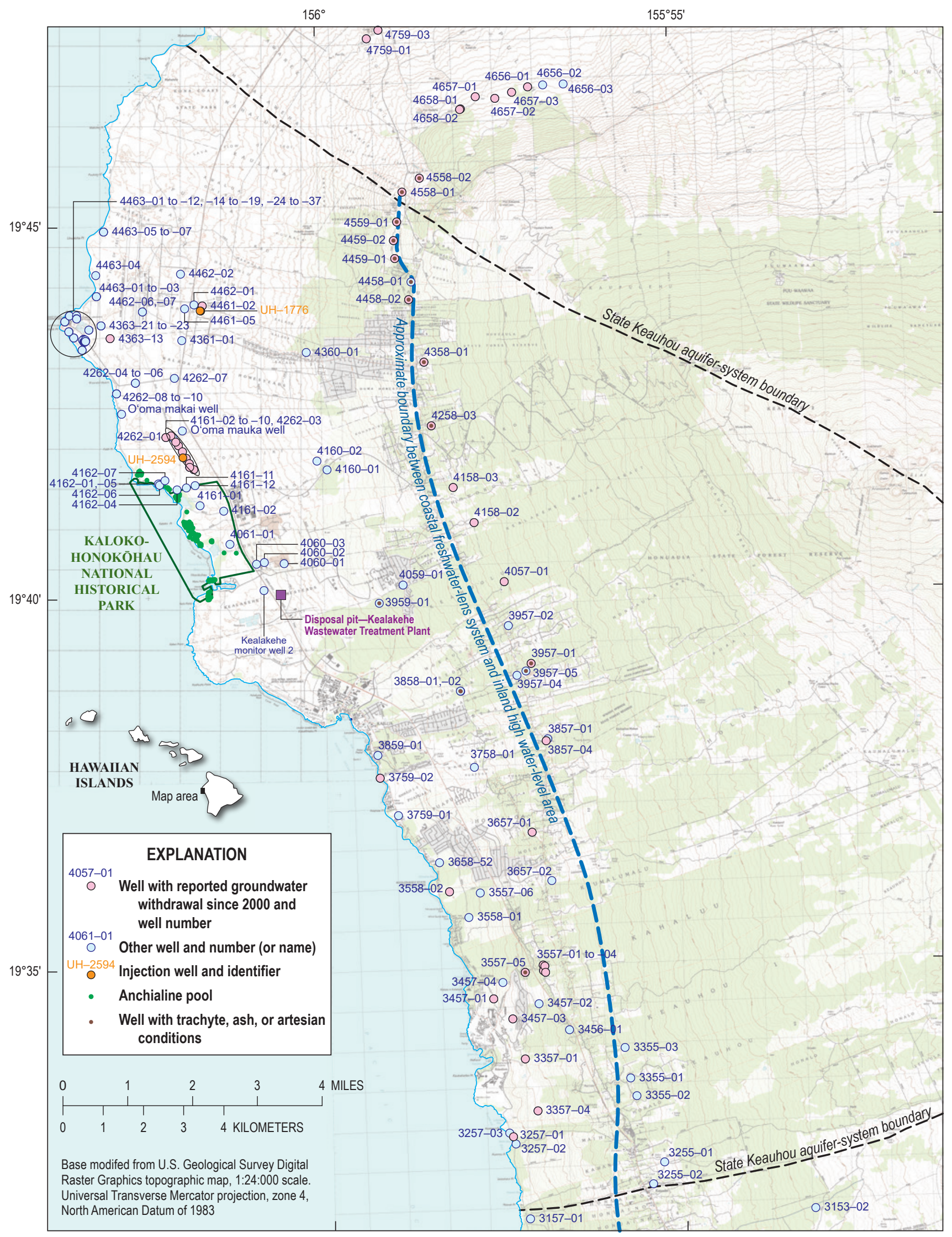

Figure 7. Map showing the approximate boundary between coastal freshwater-lens system and inland high water-level area in the Keauhou aquifer system and wells, island of Hawai'i, Hawai'i. 


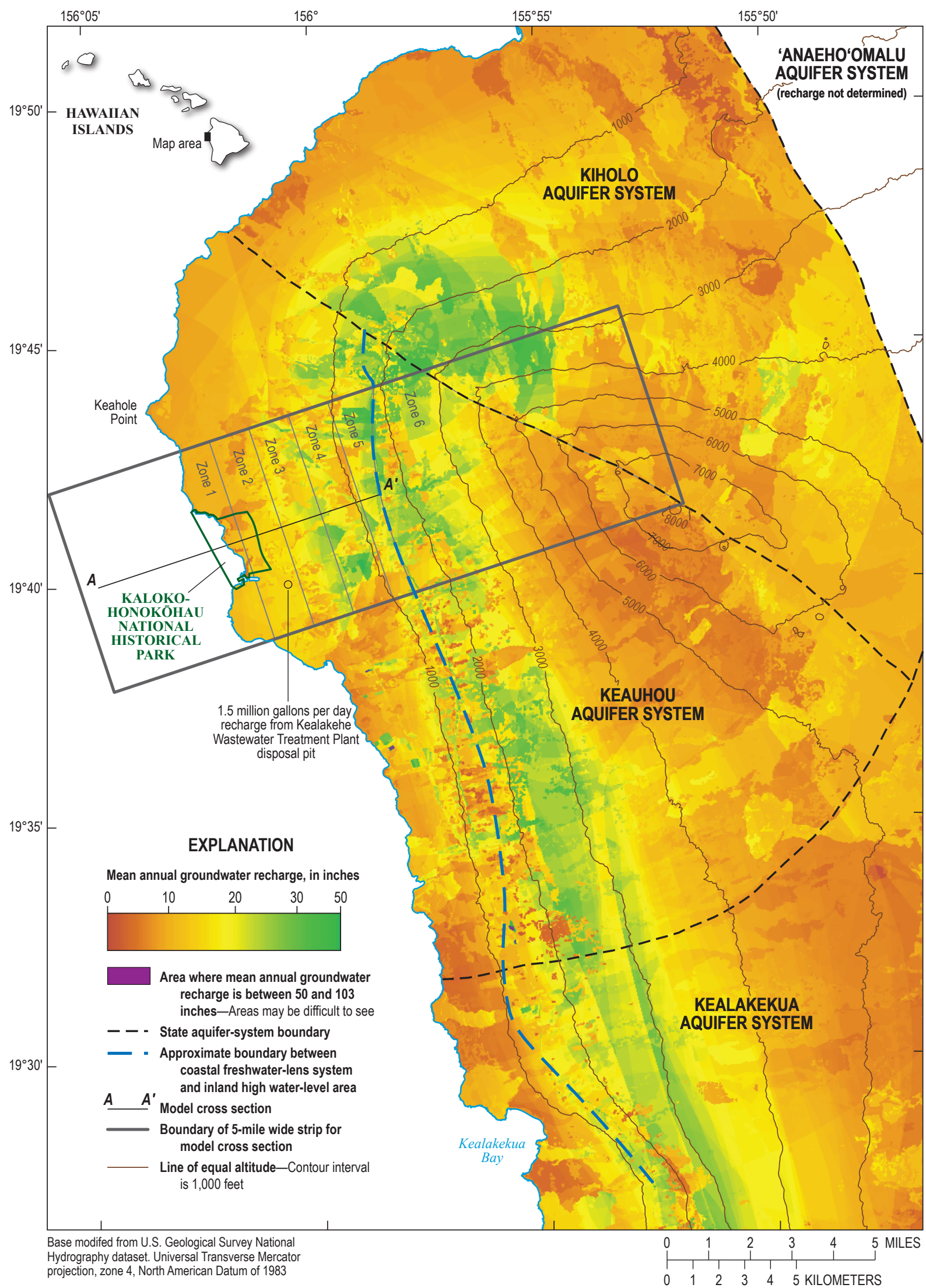

Figure 8. Map showing mean annual recharge distribution for 1984-2008 in the Kona area, island of Hawaili, Hawaili. The six numbered zones shown within the boundary of the 5-mile-wide strip represent zones for which area-weighted average recharge was determined and represented in the cross-section model. Recharge data are from Engott (2011). 


\section{Tidal Effects}

Ocean tides affect groundwater levels in the coastal freshwater-lens system of the study area. During some periods, the range (minimum to maximum) in ocean tide over a day may vary by more than $3 \mathrm{ft}$ near the study area, and this tidal signal propagates inland through the groundwater body. Because the permeability of the dike-free volcanic rocks in the study area is high, substantial groundwater-level variations in response to ocean tides have been measured in wells more than 2 mi from the coast.

For this study, continuous groundwater-level data were collected from 14 sites during 2009-10 using a 10-minute sampling interval to evaluate the tidal response in the freshwater-lens system. Data from two additional sites collected by CWRM (well 3457-04; Patrick Casey, Hawai' $i$ Commission on Water Resource Management, written commun., 2020) and a private company (2011-12 data from well 3959-01; Tom Nance, Tom Nance Water Resource Engineering, written commun., 2013) also were included in the analysis. Tidal constituents were fit, using a least-square error approach, to the ocean-tide and groundwater-level records to estimate tidal efficiency (ratio of groundwater-level amplitude to ocean-tide amplitude) at sites where continuous groundwater-level data were available. Concurrent ocean-tide data (6-minute sampling interval) were from the Kawaihae tide gage (fig. 1) operated by the National Oceanic and Atmospheric Administration (NOAA; National Oceanic and Atmospheric Administration, 2010).

Groundwater-level records were separated into 50-day periods for analysis, although tidal constituents were fit to only the middle 30 days of each 50-day period. Before fitting the tidal constituents, data were filtered using a fourth-order elliptic bandpass filter with a passband of 0.6 to 4 cycles per day, a stopband attenuation of 100 decibels $(\mathrm{dB})$, and a passband ripple of $0.05 \mathrm{~dB}$. After filtering each time series in the forward direction, the filtered sequence was reversed and run back through the filter a second time to eliminate phase distortion. For each 50-day period, the first 10 days and last 10 days of record were discarded to avoid filter end effects, and the middle 30 days were used to fit the tidal constituents. For each site, each 30-day period used to fit the tidal constituents represented a nonoverlapping period of data. Average tidal efficiencies at each site were computed from the 30-day, nonoverlapping periods of data. Sites included in this study had 1-15 independent 30 -day periods available for analysis (table 1).

Table 1. Estimated tidal efficiencies from groundwater-level records at selected wells and anchialine pools and corresponding analysis periods, Keauhou area, Hawai'i.

[--, not available or not applicable]

\begin{tabular}{|c|c|c|c|c|c|}
\hline Well number & Site name & $\begin{array}{l}{ }^{1} \text { Average diurnal tidal } \\
\text { efficiency (standard deviation in } \\
\text { parentheses) }\end{array}$ & $\begin{array}{l}{ }^{2} \text { Average semidiurnal tidal } \\
\text { efficiency (standard deviation } \\
\text { in parentheses) }\end{array}$ & \multicolumn{2}{|c|}{${ }^{350-d a y ~ a n a l y s i s ~ p e r i o d ~}$} \\
\hline \multirow[t]{3}{*}{$3457-04$} & Kahalu‘u deep monitor well & $0.59(0.004)$ & $0.51(0.015)$ & $05 / 20 / 2009$ & $07 / 08 / 2009$ \\
\hline & & & & $06 / 19 / 2009$ & 08/07/2009 \\
\hline & & & & $07 / 19 / 2009$ & $09 / 06 / 2009$ \\
\hline \multirow{3}{*}{$3858-01$} & & & & $05 / 18 / 2009$ & $07 / 06 / 2009$ \\
\hline & & & & $06 / 17 / 2009$ & $08 / 05 / 2009$ \\
\hline & & & & $07 / 17 / 2009$ & $09 / 04 / 2009$ \\
\hline \multirow[t]{7}{*}{ 3859-01 } & Dug well near Walua Road & $0.63(0.016)$ & $0.58(0.026)$ & $05 / 14 / 2009$ & $07 / 02 / 2009$ \\
\hline & & & & $09 / 11 / 2009$ & $10 / 30 / 2009$ \\
\hline & & & & $10 / 11 / 2009$ & $11 / 29 / 2009$ \\
\hline & & & & $11 / 10 / 2009$ & $12 / 29 / 2009$ \\
\hline & & & & $12 / 10 / 2009$ & $01 / 28 / 2010$ \\
\hline & & & & $01 / 09 / 2010$ & $02 / 27 / 2010$ \\
\hline & & & & $02 / 08 / 2010$ & $03 / 29 / 2010$ \\
\hline
\end{tabular}


Table 1.-Continued

\begin{tabular}{|c|c|c|c|c|c|}
\hline \multirow{2}{*}{ Well number } & \multirow{2}{*}{ Site name } & \multirow{2}{*}{$\begin{array}{c}\text { 'Average diurnal tidal } \\
\text { efficiency (standard deviation in } \\
\text { parentheses) }\end{array}$} & \multirow{2}{*}{$\begin{array}{l}{ }^{2} \text { Average semidiurnal tidal } \\
\text { efficiency (standard deviation } \\
\text { in parentheses) }\end{array}$} & \multicolumn{2}{|c|}{ 350-day analysis period } \\
\hline & & & & Initial day & Final day \\
\hline \multirow[t]{13}{*}{ 3959-01 } & Kamakana well & $0.34(0.012)$ & $0.22(0.011)$ & $08 / 07 / 2011$ & $09 / 25 / 2011$ \\
\hline & & & & 09/06/2011 & 10/25/2011 \\
\hline & & & & $10 / 06 / 2011$ & $11 / 24 / 2011$ \\
\hline & & & & $11 / 05 / 2011$ & $12 / 24 / 2011$ \\
\hline & & & & $12 / 05 / 2011$ & 01/23/2012 \\
\hline & & & & 01/04/2012 & 02/22/2012 \\
\hline & & & & 02/03/2012 & 03/23/2012 \\
\hline & & & & 03/04/2012 & $04 / 22 / 2012$ \\
\hline & & & & $04 / 03 / 2012$ & 05/22/2012 \\
\hline & & & & 05/03/2012 & $06 / 21 / 2012$ \\
\hline & & & & $06 / 02 / 2012$ & 07/21/2012 \\
\hline & & & & 07/02/2012 & 08/20/2012 \\
\hline & & & & $09 / 22 / 2012$ & $11 / 10 / 2012$ \\
\hline \multirow[t]{10}{*}{--} & Kealakehe monitor well 2 & $0.55(0.014)$ & $0.48(0.035)$ & $09 / 17 / 2009$ & $11 / 05 / 2009$ \\
\hline & & & & $10 / 17 / 2009$ & $12 / 05 / 2009$ \\
\hline & & & & $11 / 16 / 2009$ & $01 / 04 / 2010$ \\
\hline & & & & $12 / 16 / 2009$ & $02 / 03 / 2010$ \\
\hline & & & & $01 / 15 / 2010$ & 03/05/2010 \\
\hline & & & & 02/14/2010 & $04 / 04 / 2010$ \\
\hline & & & & $04 / 16 / 2010$ & $06 / 04 / 2010$ \\
\hline & & & & 05/16/2010 & $07 / 04 / 2010$ \\
\hline & & & & $06 / 15 / 2010$ & 08/03/2010 \\
\hline & & & & 07/15/2010 & 09/02/2010 \\
\hline \multirow[t]{11}{*}{ 4061-01 } & KAHO well 1 & $0.54(0.008)$ & $0.49(0.033)$ & 04/09/2009 & 05/28/2009 \\
\hline & & & & 05/09/2009 & $06 / 27 / 2009$ \\
\hline & & & & $07 / 24 / 2009$ & $09 / 11 / 2009$ \\
\hline & & & & $08 / 23 / 2009$ & $10 / 11 / 2009$ \\
\hline & & & & $09 / 22 / 2009$ & $11 / 10 / 2009$ \\
\hline & & & & $12 / 02 / 2009$ & $01 / 20 / 2010$ \\
\hline & & & & $01 / 01 / 2010$ & $02 / 19 / 2010$ \\
\hline & & & & $01 / 31 / 2010$ & $03 / 21 / 2010$ \\
\hline & & & & 04/17/2010 & $06 / 05 / 2010$ \\
\hline & & & & 05/17/2010 & $07 / 05 / 2010$ \\
\hline & & & & 06/16/2010 & $08 / 04 / 2010$ \\
\hline \multirow[t]{7}{*}{ 4160-02 } & Kaloko irrigation 2 & $0.30(0.009)$ & $0.20(0.013)$ & $04 / 18 / 2009$ & 06/06/2009 \\
\hline & & & & 05/18/2009 & 07/06/2009 \\
\hline & & & & $06 / 17 / 2009$ & $08 / 05 / 2009$ \\
\hline & & & & $07 / 17 / 2009$ & $09 / 04 / 2009$ \\
\hline & & & & $09 / 10 / 2009$ & $10 / 29 / 2009$ \\
\hline & & & & $10 / 10 / 2009$ & $11 / 28 / 2009$ \\
\hline & & & & $12 / 02 / 2009$ & $01 / 20 / 2010$ \\
\hline
\end{tabular}


Table 1.-Continued

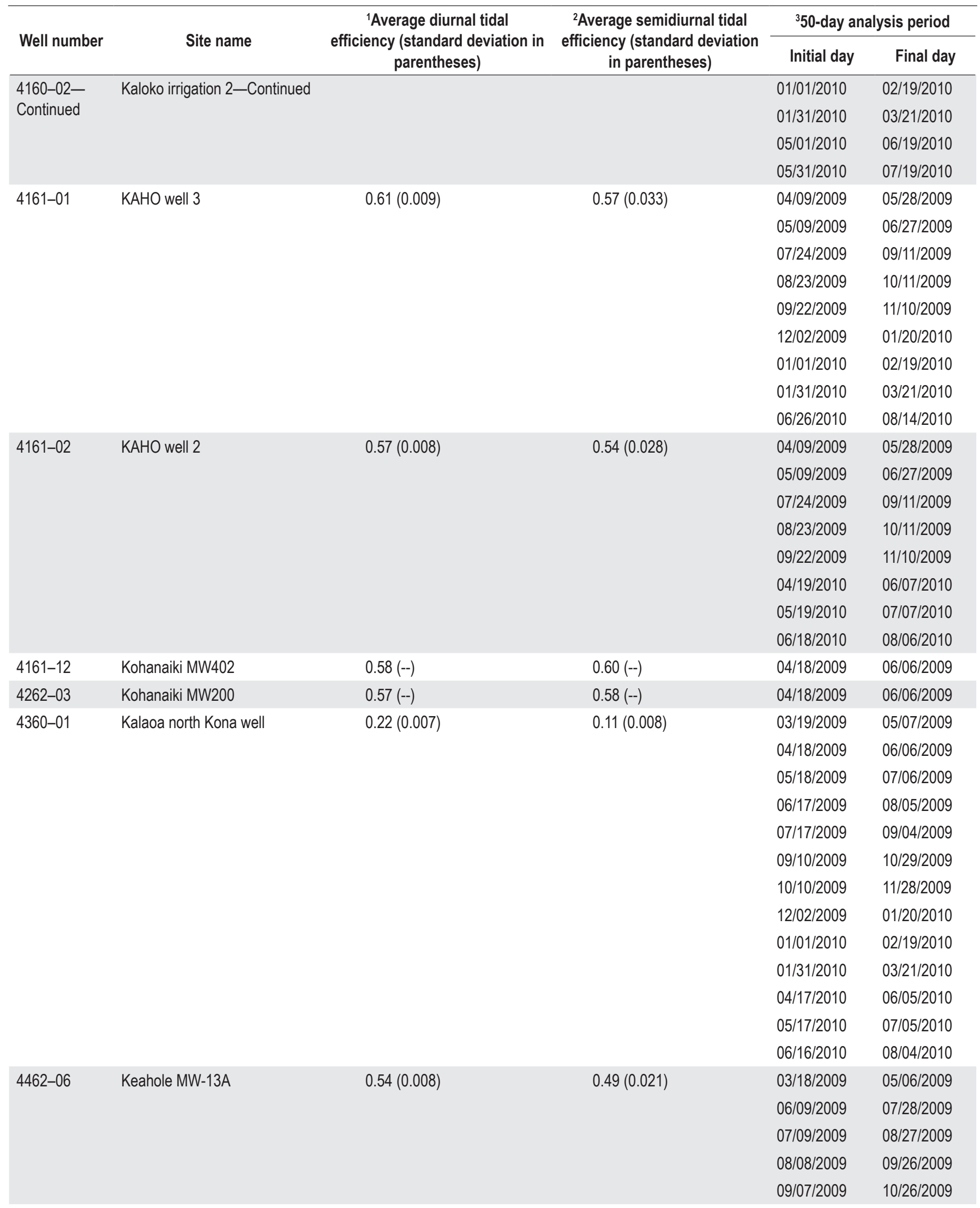


Table 1.-Continued

\begin{tabular}{|c|c|c|c|c|c|}
\hline \multirow{2}{*}{ Well number } & \multirow{2}{*}{ Site name } & \multirow{2}{*}{$\begin{array}{l}{ }^{1} \text { Average diurnal tidal } \\
\text { efficiency (standard deviation in } \\
\text { parentheses) }\end{array}$} & \multirow{2}{*}{$\begin{array}{l}{ }^{2} \text { Average semidiurnal tidal } \\
\text { efficiency (standard deviation } \\
\text { in parentheses) }\end{array}$} & \multicolumn{2}{|c|}{ 350-day analysis period } \\
\hline & & & & Initial day & Final day \\
\hline \multirow[t]{15}{*}{--} & Anchialine pool $53 \mathrm{H}$ & $0.71(0.015)$ & $0.71(0.044)$ & 03/20/2009 & $05 / 08 / 2009$ \\
\hline & & & & $04 / 19 / 2009$ & $06 / 07 / 2009$ \\
\hline & & & & 05/19/2009 & $07 / 07 / 2009$ \\
\hline & & & & $06 / 18 / 2009$ & 08/06/2009 \\
\hline & & & & 07/18/2009 & 09/05/2009 \\
\hline & & & & 08/17/2009 & $10 / 05 / 2009$ \\
\hline & & & & 09/16/2009 & $11 / 04 / 2009$ \\
\hline & & & & $10 / 16 / 2009$ & $12 / 04 / 2009$ \\
\hline & & & & $11 / 15 / 2009$ & 01/03/2010 \\
\hline & & & & $12 / 15 / 2009$ & 02/02/2010 \\
\hline & & & & $01 / 14 / 2010$ & 03/04/2010 \\
\hline & & & & $02 / 13 / 2010$ & 04/03/2010 \\
\hline & & & & 04/18/2010 & 06/06/2010 \\
\hline & & & & 05/18/2010 & 07/06/2010 \\
\hline & & & & 06/17/2010 & 08/05/2010 \\
\hline \multirow[t]{6}{*}{--} & Anchialine pool $83 \mathrm{C}$ & $0.89(0.030)$ & $1.02(0.088)$ & $06 / 24 / 2009$ & $08 / 12 / 2009$ \\
\hline & & & & $07 / 24 / 2009$ & 09/11/2009 \\
\hline & & & & $01 / 01 / 2010$ & 02/19/2010 \\
\hline & & & & 04/18/2010 & 06/06/2010 \\
\hline & & & & $05 / 18 / 2010$ & 07/06/2010 \\
\hline & & & & 06/17/2010 & 08/05/2010 \\
\hline \multirow[t]{13}{*}{--} & Anchialine pool 118 & $0.71(0.017)$ & $0.73(0.058)$ & $04 / 18 / 2009$ & 06/06/2009 \\
\hline & & & & 05/18/2009 & $07 / 06 / 2009$ \\
\hline & & & & $06 / 17 / 2009$ & 08/05/2009 \\
\hline & & & & 07/17/2009 & $09 / 04 / 2009$ \\
\hline & & & & $09 / 17 / 2009$ & $11 / 05 / 2009$ \\
\hline & & & & $11 / 13 / 2009$ & 01/01/2010 \\
\hline & & & & $12 / 13 / 2009$ & $01 / 31 / 2010$ \\
\hline & & & & $01 / 12 / 2010$ & 03/02/2010 \\
\hline & & & & $02 / 11 / 2010$ & 04/01/2010 \\
\hline & & & & $03 / 13 / 2010$ & 05/01/2010 \\
\hline & & & & $04 / 12 / 2010$ & $05 / 31 / 2010$ \\
\hline & & & & $05 / 12 / 2010$ & $06 / 30 / 2010$ \\
\hline & & & & $06 / 11 / 2010$ & 07/30/2010 \\
\hline
\end{tabular}

${ }^{1}$ Average tidal efficiency for the diurnal (O1) tidal constituent for all analysis periods.

${ }^{2}$ Average tidal efficiency for the semidiurnal (M2) tidal constituent for all analysis periods.

${ }^{3}$ First 10 days and last 10 days of the 50-day period not used to fit the tidal constituents. 
The five tidal constituents considered were O1 (lunar, diurnal principal constituent), K1 (lunar-solar, diurnal declinational constituent), M2 (lunar, semidiurnal principal constituent), S2 (solar, semidiurnal principal constituent), and N2 (lunar, semidiurnal elliptic constituent). Fitted K1 and $\mathrm{S} 2$ constituents may be affected by barometric pressure variations and therefore are not used here to estimate tidal efficiencies. The $\mathrm{N} 2$ constituent is relatively small and also is not considered. The $\mathrm{O} 1$ and $\mathrm{M} 2$ tidal efficiencies decrease with distance from the coast (fig. 9). Both the $\mathrm{O} 1$ and M2 tidal efficiencies exceed 0.45 in wells within about $0.5 \mathrm{mi}$ from the coast. The $\mathrm{O} 1$ tidal efficiency is 0.22 in well $4360-01$, which is about $3 \mathrm{mi}$ inland. A tidal efficiency approaching this magnitude at a comparable distance from the coast within volcanic rocks is not known to exist on any of the other Hawaiian islands. The high tidal efficiency near the study area reflects the high permeability of the volcanic rocks in the area.

In general, higher frequency groundwater-level variations are attenuated to a greater extent with distance from the source of the change than lower frequency variations because the aquifer tends to preferentially filter out the higher frequency signals. Thus, higher frequency tidal constituents are expected to be attenuated to a greater extent than lower frequency constituents with distance from the coast. This generally is the case in the study area, particularly at the most inland wells, where the M2 efficiency is lower than the $\mathrm{O} 1$ efficiency (fig. 9).

Groundwater levels in the freshwater-lens system in the study area can indicate an efficiency greater than 1 at sites where the ocean tide can affect the groundwater from multiple directions. In coastal land areas that jut out into the ocean, the ocean tide can affect groundwater from multiple directions. Constructive interference of the ocean-tide signal from multiple directions can cause the groundwater level to vary by more than 100 percent of the ocean tide (see for example, Rotzoll and others, 2008). This type of constructive interference of ocean-tide signal may be present in an anchialine pool on the coastal point just north of the mouth of Honokōhau Harbor (fig. 9), where the M2 tidal efficiency slightly exceeds 1.

\section{Synoptic Water-Level Distribution}

Because groundwater levels are strongly affected by ocean tides, synoptic water-level surveys using one-time, instantaneous measurements at selected wells may not provide an accurate indication of the spatial distribution of water levels in the study area. Thus, daily average groundwater levels were determined for selected days corresponding to periods of high ocean level (August 7, 2009), low ocean level (April 18, 2009), and mean sea level (May 18 and October 2, 2009). The daily average groundwater levels (fig. 10) indicate that during a period of high ocean level, groundwater levels are correspondingly high, whereas during a period of low ocean level, groundwater levels are low. At a given site, daily average groundwater levels on selected days during periods when the ocean level is near mean sea level are comparable or the same (fig. 10).

Daily average groundwater levels in the freshwaterlens system near KAHO are higher in inland areas relative to coastal areas. Daily average groundwater levels exceed $2.5 \mathrm{ft}$ above mean sea level in wells greater than about $2 \mathrm{mi}$ from the coast, whereas groundwater levels are less than $2 \mathrm{ft}$ above mean sea level within $0.5 \mathrm{mi}$ from the coast (fig. 10). This pattern of groundwater levels generally is consistent with the distribution of groundwater levels in the Keauhou aquifer system described by Bauer (2003).

In a homogeneous, isotropic, unconfined coastal aquifer with steady, uniform, horizontal flow, the horizontal hydraulic head gradient will increase in the downgradient, seaward direction and the magnitude and direction of the hydraulic gradient can be determined from the squared heads at a trio of sites (Silliman and Frost, 1998). The method of Silliman and Frost (1998) is applicable to an idealized aquifer and was used to provide a general depiction of hydraulic gradients in the study area even though the assumptions of the method may not be entirely met. Cole and Silliman (1996) indicated that in a heterogeneous aquifer, the bias of the regional hydraulic gradient estimated from the squared heads tends to decrease as the separation between wells increases. For this study, trios of sites for which average groundwater levels (heads) could be computed for a common period were selected to estimate the magnitude and direction of an average hydraulic gradient. Selected trios of sites were limited to those for which all internal angles (formed by the triangle in the horizontal plane defined by the three sites) are between 30 and 90 degrees. This limited the trios to those with a reasonable spatial distribution of sites that are expected to produce the most reasonable hydraulic-gradient estimates. Using all selected trios of sites and squared average heads during the period September 21 through October 20, 2009, the horizontal hydraulic head gradients near KAHO are estimated to be about $0.5 \mathrm{ft} / \mathrm{mi}$ at well sites more than $2 \mathrm{mi}$ from the coast; about $1 \mathrm{ft} / \mathrm{mi}$ at well sites $0.5-1 \mathrm{mi}$ from the coast; and greater than $1 \mathrm{ft} / \mathrm{mi}$ at anchialine pool sites within $0.25 \mathrm{mi}$ from the coast (fig. 11). During the period September 21 through October 20, 2009, the ocean level was near mean sea level, and thus the estimated hydraulic gradients are for mean sea level conditions. Local hydraulic gradients may differ from those estimated for this study. The magnitude and direction of the hydraulic gradient at a site may differ from the average regional values estimated for this study (fig. 11) because of (1) temporal variations in head caused by changes in ocean level, (2) temporal variability in recharge, (3) local sources or sinks of water, (4) aquifer heterogeneity and anisotropy, and (5) vertical flow.

Figure 9. Map showing tidal efficiency during 2009-10, estimated from groundwater levels recorded in selected wells and anchialine pools in the Keauhou aquifer system, island of Hawai'i, Hawaii'i. 01, lunar, diurnal principal constituent; M2, lunar, semidiurnal principal constituent. Data used to compute tidal efficiencies are from U.S. Geological Survey (2020) unless indicated by footnote. 


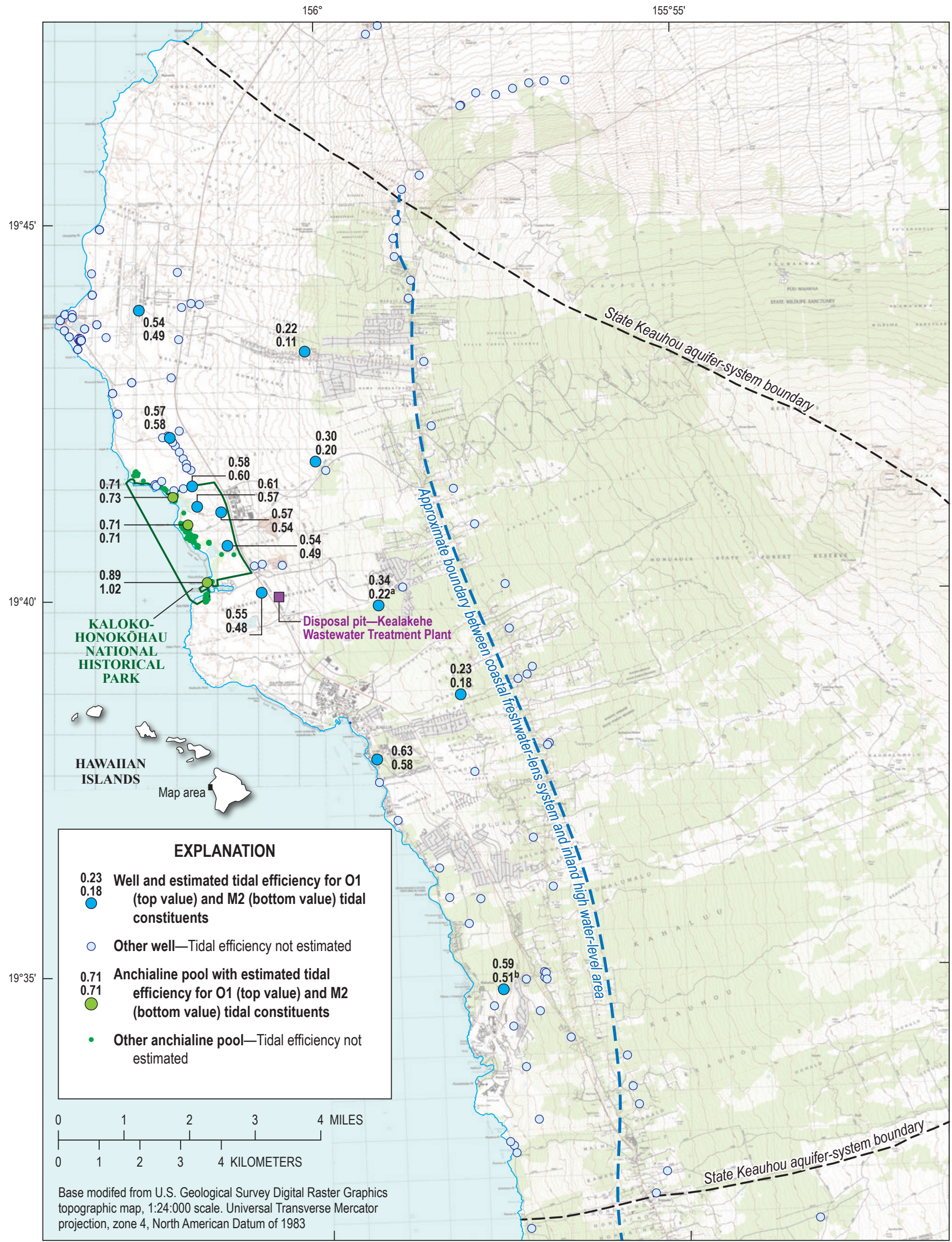

aData used to compute tidal efficiencies from Tom Nance, Tom Nance Water Resource Engineering, written commun. (2013)

${ }^{b}$ Data used to compute tidal efficiencies from Patrick Casey, Hawai'i Commission on Water Resource Management, written commun. (2020) 


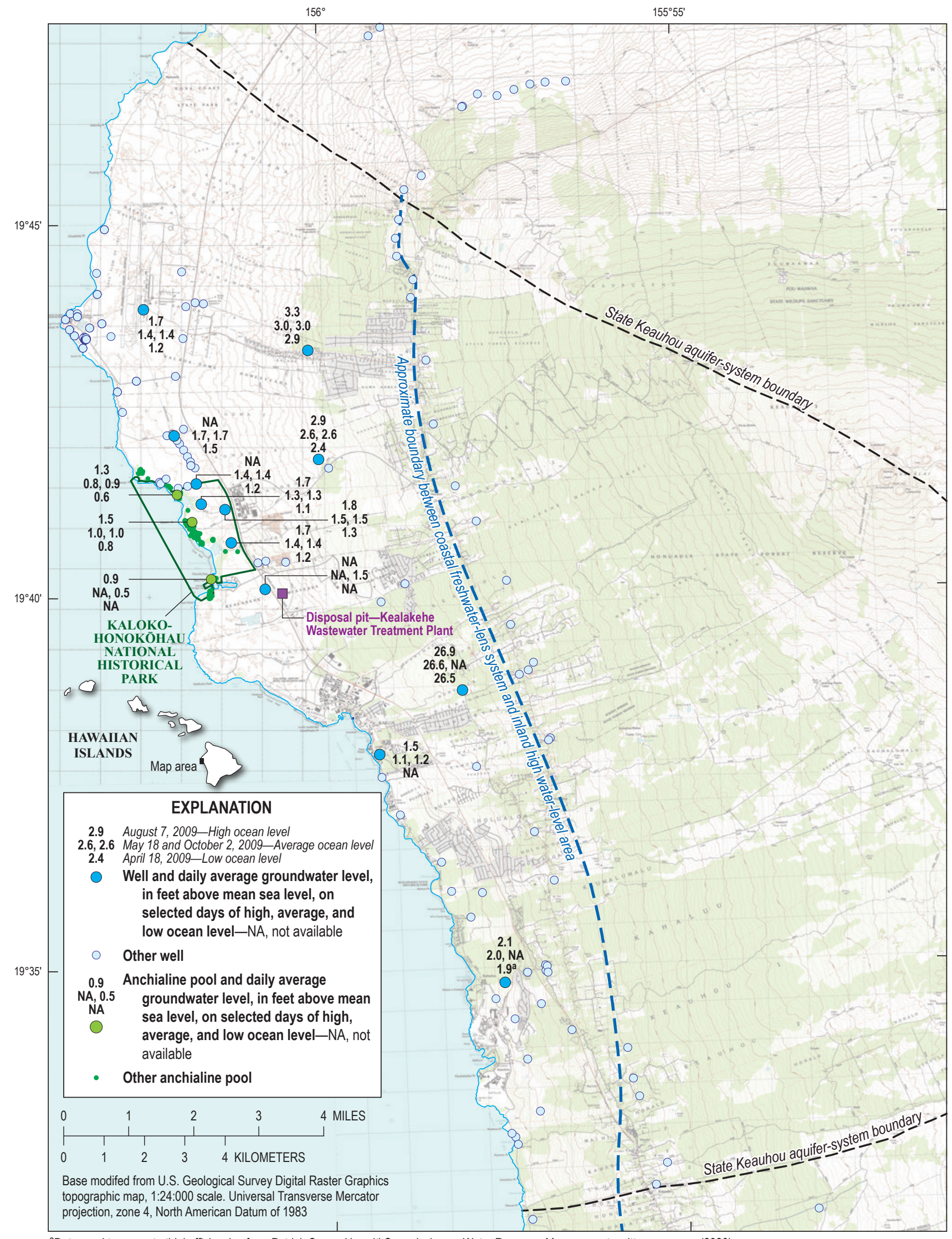

'Data used to compute tidal efficiencies from Patrick Casey, Hawai'i Commission on Water Resource Management, written commun. (2020)

Figure 10. Map showing the daily average groundwater levels on August 7, 2009 (period of high ocean level); May 18 and October 2, 2009 (period of near mean sea level); and April 18, 2009 (period of low ocean level) in selected wells and anchialine pools in the Keauhou aquifer system, island of Hawai' i, Hawai'i. Data used to compute daily average groundwater levels are from U.S. Geological Survey (2020) unless indicated by footnote. 


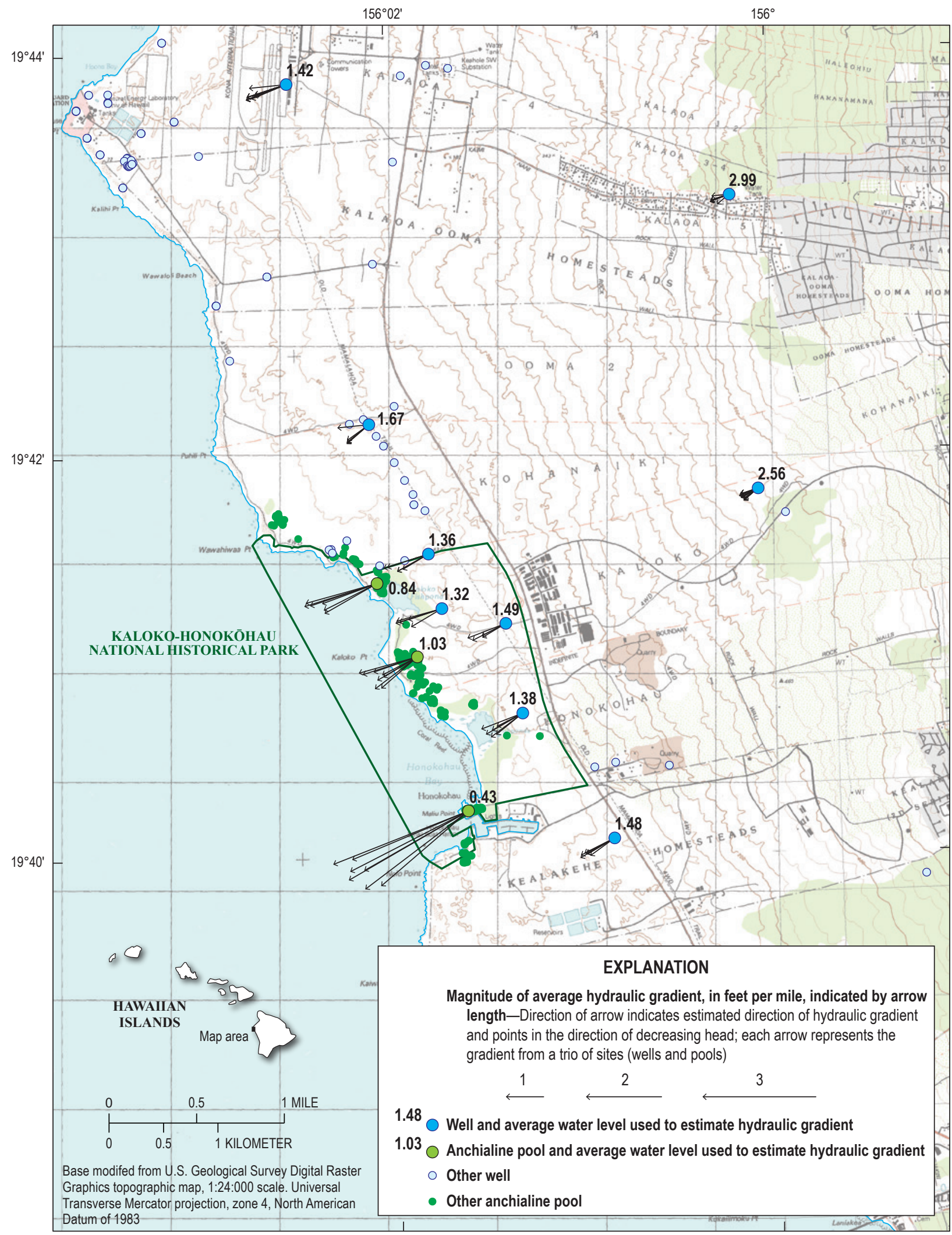

Figure 11. Map showing magnitude and direction of estimated average hydraulic gradient during the period from September 21 to October 20, 2009, using groundwater levels from selected wells and anchialine pools in the Keauhou aquifer system, island of Hawai'i, Hawaili. The magnitude and direction of the average hydraulic gradient indicated by each arrow are estimated from groundwater levels at three sites, assuming a planar surface defined by the squared average heads at the three sites. For each trio of sites, all internal angles of the triangle formed by the sites are between 30 and 90 degrees. Groundwater-level data used to estimate gradients are from U.S. Geological Survey (2020). 


\section{Salinity}

Within the Keauhou aquifer system, available data indicate that the coastal freshwater-lens system in the dike-free volcanic rocks within and north of KAHO mainly is composed of brackish water overlying saltwater, with the brackishwater zone extending from the water table to the underlying saltwater. South of KAHO, freshwater may overlie brackish water in places, with the freshwater zone extending from the water table to the underlying brackish water. A few wells south of KAHO near Hōlualoa (3657-01) and Keauhou (3557-01 to -05$)$ produce freshwater from the coastal freshwater-lens system. Several inland wells north of KAHO (4458-01, 4458-02, 4459-01, 4459-02, and 4559-01), near the northeast boundary of the Keauhou aquifer system, have water levels that exceed mean sea level by more than a few feet and that may be affected by dikes or confining units (Bauer, 2003).

In general, salinity of groundwater within the coastal freshwater-lens system is expected to increase with depth and decrease with distance from the coast, all other factors being equal. Vertical salinity profiles (as measured by fluid specific conductance, with fluid specific conductance of $53,800 \mu \mathrm{S} / \mathrm{cm}$ assumed to correspond to 100 percent ocean-water salinity) from wells in the study area generally indicate increasing salinity with depth, although water with salinity equal to that of ocean water is not always found at the bottom of the wells

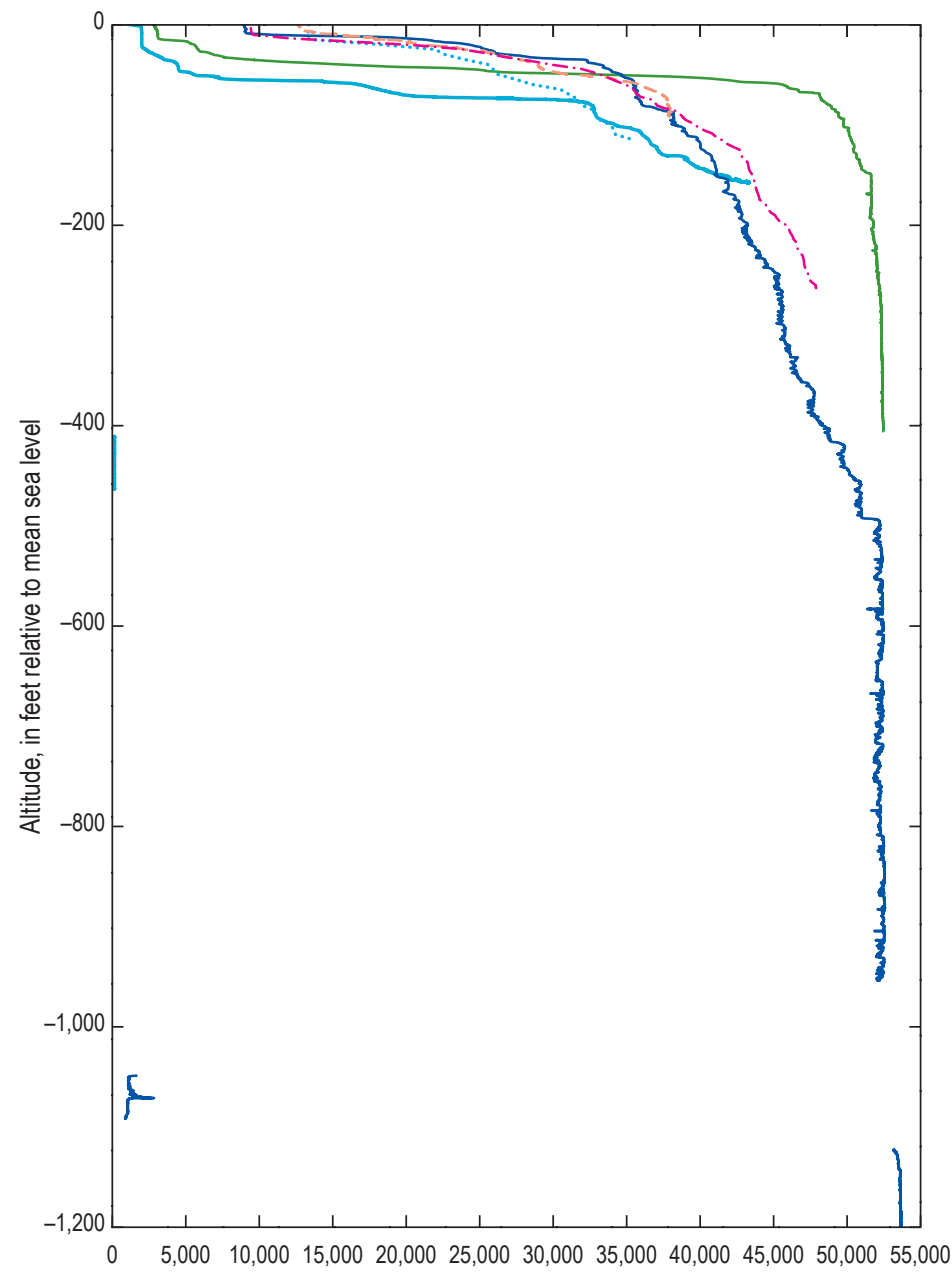

Fluid specific conductance, in microsiemens per centimeter at 25 degrees Celsius (fig. 12). Deep monitoring wells exist north and south of KAHO and vertical salinity profiles from these wells indicate water with salinity approaching ocean-water salinity above the bottoms of the wells (fig. 12). North of KAHO, a salinity profile from Keahole power plant injection well UH-1776 (Norris Uehara, Hawai'i Department of Health, Safe Drinking Water Branch, written commun., 2014) indicates salinity approaching that of ocean water near an altitude of $-250 \mathrm{ft}$ (fig. 12). South of KAHO, the salinity profile in the Kamakana well (3959-01) indicates a salinity of about 10 percent that of ocean water near the water table, and salinity increases gradually to about that of ocean water near an altitude of -500 ft (fig. 12; Tom Nance, Tom Nance Water Resource Engineering, written commun., 2012). The salinity profile in the Kahalu'u deep monitor well (3457-04), near the southern part of the Keauhou aquifer system, has a salinity of about 4-5 percent that of ocean water near the water table, and salinity increases relatively sharply to about that of ocean water near an altitude of $-150 \mathrm{ft}$ (fig. 12).

\section{Temperature}

Within the Keauhou aquifer system, groundwater temperatures within the coastal freshwater-lens system generally range from about 15 to $25^{\circ} \mathrm{C}$ and may be affected by cold saltwater that originates from the ocean (Tom Nance

\section{EXPLANATION}

3959-01, Kamakana deep monitor well, composite from
April 3, 2010, May 12, 2010, and August 18, 2010-
From Tom Nance, Tom Nance Water Resource
Engineering, written commun. (2012)
3858-01, Keopu 1 deep moinitor well above an altitude of
-200 ft, December 10, 2019; 3858-02, Keopu 2 deep
monitor well below an altitude of -400 ft, October 24,
2017-From Patrick Casey, Hawai'i Commission on Water
Resource Management, written commum. (2020)
3457-04, Kahalu'u deep monitor well, May 19, 2009_From
Patrick Casey, Hawai'i Commission on Water Resource
Management, written commun. (2020)
0‘oma mauka well, April 27, 2012-From Tom Nance,
Tom Nance Water Resource Engineering, written
commun. (2012)
19, 1993-From Norris Uehara, Hawai'i Department of
Health, Safe Drinking Water Branch, written commun.
(2014)

Figure 12. Line graph showing fluid specific-conductance profiles from wells in the Keauhou area, Hawai'i. 
Water Resource Engineering, 2002; Bowles, 2007). Oceanwater temperatures generally are colder than $20^{\circ} \mathrm{C}$ below an altitude of about $-500 \mathrm{ft}$, and colder than $15^{\circ} \mathrm{C}$ below an altitude of about $-800 \mathrm{ft}$ (fig. 5). Water-temperature profiles are available from monitoring wells and generally indicate decreasing temperature with depth, although temperature may increase with depth in places where relatively warm saltwater, originating from the ocean, flows in the aquifer (fig. 5). For example, increasing temperature with depth in the Kahalu'u deep monitor well (3457-04) from about 20 to $23{ }^{\circ} \mathrm{C}$ between altitudes of -50 and $-150 \mathrm{ft}$ (fig. 5) may reflect inflow of warm saltwater from shallow ocean depths. The temperature profile from the Kamakana well (3959-01) indicates generally decreasing temperature with depth from the water table to an altitude of $-320 \mathrm{ft}$, from about $19^{\circ} \mathrm{C}$ near the water table to about $17^{\circ} \mathrm{C}$ at an altitude of $-320 \mathrm{ft}$; increasing temperature with depth between altitudes of -320 and $-500 \mathrm{ft}$, from about $17^{\circ} \mathrm{C}$ at an altitude of $-320 \mathrm{ft}$ to about $20^{\circ} \mathrm{C}$ at $-500 \mathrm{ft}$; and generally monotonically decreasing temperature with depth below an altitude of $-500 \mathrm{ft}$ (fig. 5; Tom Nance, Tom Nance Water Resource Engineering, written commun., 2012). The temperature profile in the Kamakana well mainly reflects the mixture of water derived from recharge and from various depths in the ocean.

\section{Coastal Confined-Groundwater System}

Drilled wells provide evidence for a deep coastal confined-groundwater system that exists below the coastal freshwater-lens system. The most compelling evidence of a deep coastal confined-groundwater system in the study area is from the Kamakana well (3959-01) (fig. 7), although hydrologic and geologic information from other wells also indicate a coastal confined-groundwater system.

\section{Kamakana Well, 3959-01}

A composite vertical salinity profile from the Kamakana well (3959-01) was constructed using salinity-profile data from April 3, 2010 (from the water table to an altitude of -954 ft); May 12, 2010 (from -1,049 to -1,092 ft); and August 18, 2010 (below an altitude of $-1,137 \mathrm{ft}$ ) (fig. 12; Tom Nance, Tom Nance Water Resource Engineering, written commun., 2012). The salinity profile from April 3, 2010, is assumed to be generally representative of salinity in the aquifer above an altitude of $-954 \mathrm{ft}$, although it is possible that borehole flow may be affecting the measured profile (Rotzoll, 2010, 2012). Comparison of complete salinity profiles from April 3, 2010, and May 12, 2010, indicates that the salinity profile from May 12,2010 , between altitudes of about -150 and $-1,049 \mathrm{ft}$, is affected by upward flow of the deep coastal confined fresher groundwater that mixes with existing water in the borehole. Similarly, the complete salinity profile from August 18, 2010, between altitudes of about -50 and $-1,137 \mathrm{ft}$, is affected by borehole flow and is not representative of water quality in the adjacent aquifer in this depth range. The composite salinity profile indicates brackish water near the water table, generally increasing salinity with depth to an altitude of about $-500 \mathrm{ft}$, groundwater with salinity nearly that of ocean water from about -500 to $-954 \mathrm{ft}$, groundwater that is nearly freshwater between altitudes of about $-1,050$ and $-1,100 \mathrm{ft}$, and groundwater with salinity nearly that of ocean water below an altitude of $-1,137 \mathrm{ft}$ (fig. 12). Thus, the composite salinity profile indicates a layered groundwater system consisting of a coastal freshwater-lens system (unconfined brackish water underlain by groundwater with salinity nearly that of ocean water), underlain by a confined-groundwater system between altitudes of about $-1,050$ and $-1,100 \mathrm{ft}$, which in turn is underlain by saltwater. The transition between the confined freshwater and underlying saltwater is relatively sharp, occurring within a relatively thin zone that is less than $50-\mathrm{ft}$ thick. In comparison, the brackish-water zone in the coastal lens is about $500-\mathrm{ft}$ thick.

The groundwater level in the coastal freshwater-lens system is about $3 \mathrm{ft}$ above mean sea level, whereas the head in the deeper confined groundwater body is estimated to be about $35 \mathrm{ft}$ (Tom Nance, Tom Nance Water Resource Engineering, written commun., 2012). This head difference indicates that groundwater may discharge from the confined groundwater system upward to the coastal freshwater-lens system but not from the coastal freshwater-lens system into the confined groundwater system. Discharge of the confined groundwater also may be downward into the underlying saltwater or directly to the ocean. Groundwater levels in the confined zone are affected by ocean tides, indicating a hydrologic connection between the confined groundwater and the ocean.

\section{Keopu 1 Deep Monitor Well, 3858-01}

Water levels measured during drilling of the Keopu 1 deep monitor well (3858-01) were about $5 \mathrm{ft}$ above mean sea level when the bottom of the well was at an altitude of about $-20 \mathrm{ft}$, and increased to greater than $25 \mathrm{ft}$ when the bottom of the well was at a final altitude of about $-575 \mathrm{ft}$ (Bauer, 2003). A CWRM video log from January 21, 2014, from the Keopu 1 deep monitor well (Patrick Casey, Hawai'i Commission on Water Resource Management, written commun., 2014) shows upward borehole flow (determined from upward moving particles in the water column observed when the camera was stationary) between altitudes of about -100 and $-550 \mathrm{ft}$, with strong inflow zones (determined from zones where numerous, vigorously moving and circulating particles nearly obscure the video image) between altitudes of about -200 and $-260 \mathrm{ft}$.

A salinity profile from January 30,2014 , from the Keopu 1 deep monitor well indicates freshwater (specific conductance less than $150 \mu \mathrm{S} / \mathrm{cm}$ ) throughout the water column of the open part of the borehole between altitudes of about -20 and $-575 \mathrm{ft}$ (Patrick Casey, Hawai'i Commission on Water Resource Management, written commun., 2014). The salinity profile and video log from the Keopu 1 deep monitor well indicate upward flow of freshwater in the borehole. The temperature profile from January 30, 2014, indicates nearly uniform 
temperature of about $20^{\circ} \mathrm{C}$ throughout the water column of the open part of the borehole. The vertical head gradient and evidence of upward borehole flow are consistent with information from the Kamakana well (3959-01), located about 2 mi northwest of the Keopu 1 deep monitor well, and indicate a deep confined-groundwater system.

The Keopu 1 deep monitor well was modified in August 2016 by sealing off about $400 \mathrm{ft}$ of the bottom part of the well with grout to stop the upward discharge of freshwater from the deep confined-groundwater system. Following the well modification, which raised the bottom of the well to an altitude of about $-161 \mathrm{ft}$, the water level in the well was about $2.5 \mathrm{ft}$ (State of Hawai' $\mathrm{i}, 2020$ ) and the salinity profile from December 10, 2019, indicated generally increasing salinity with depth, although saltwater was not detected at the bottom of the profile (fig. 12) (Patrick Casey, Hawai'i Commission on Water Resource Management, written commun., 2020).

\section{Keopu 2 Deep Monitor Well, 3858-02}

The Keopu 2 deep monitor well was drilled adjacent to the Keopu 1 deep monitor well in 2017 to monitor conditions in the deep coastal confined-groundwater system. The Keopu 2 deep monitor well is open to the aquifer between altitudes of about -411 to $-474 \mathrm{ft}$. Information from the Keopu 2 deep monitor well indicates a water level of about $35 \mathrm{ft}$ and a salinity corresponding to freshwater, with a specific conductance less than about $170 \mu \mathrm{S} / \mathrm{cm}$ (fig. 12; Patrick Casey, Hawai'i Commission on Water Resource Management, written commun., 2020).

\section{Inland High Water-Level Area}

The source of freshwater in the high water-level area of western Hawai' $i$ is groundwater recharge from (1) infiltration of rainfall and fog drip, (2) irrigation water, and (3) return of wastewater. Fresh groundwater in the high water-level area that is not withdrawn from wells flows to downgradient areas and discharges to the coastal confined-groundwater system, the coastal freshwater-lens system, or both.

\section{Water Levels}

Measured water levels in wells located about 2 to $4.5 \mathrm{mi}$ inland generally range from 40 to $500 \mathrm{ft}$ above sea level, although water levels exceeding 1,000 ft also have been measured in wells south of the Keauhou aquifer system. Groundwater levels are substantially higher in this area than in the downgradient, coastal freshwater-lens system. The geologic nature of the impounding structure or structures associated with the high water levels in western Hawai' $i$ is unknown. The high water levels may be caused by buried, low-permeability rocks in the form of dikes, lava-draped fault scarps, massive lava flows, regionally continuous ash deposits, or any combination of these (fig. 13). Gravity and seismic-refraction data (Zucca and others, 1982; Kauahikaua and others, 2000; Flinders and others, 2013) indicate that a dense structure, such as a buried dike complex, may exist where high water levels have been measured. In addition, aquifer tests indicate that the aquifer is compartmentalized, which could be related to the presence of dikes (Oki and others, 1999). Mass-wasting deposits related to prodigious submarine landslides have been identified off the Kona coast using sonar images (Lipman and others, 1988; Moore and others, 1989). The subaerially exposed fault system near Kealakekua Bay is associated with a large-scale submarine landslide. Additional onshore faults in western Hawai'i may be buried by younger lava flows. In places, low-permeability lava flows or ash layers may act as confining units that create artesian conditions. Although the spatial extent of these low-permeability lava flows or ash layers is poorly known, Kauahikaua and others (1998) used gravity data to suggest that a massive dipping flow, possibly trachyte, may be the cause of the high water levels. Impounded groundwater levels in the high water-level area do not appear to be measurably affected by ocean tides, which is consistent with the presence of a lowpermeability geologic structure between the high water-level area and the ocean.

\section{Salinity and Temperature}

Impounded groundwater in the high water-level area is relatively fresh, with chloride concentrations generally less than $20 \mathrm{mg} / \mathrm{L}$, representing about 0.1 percent of the chloride concentration in ocean water. Available temperature measurements of pumped groundwater in the high water-level area generally indicate water temperatures of about 20 to $22{ }^{\circ} \mathrm{C}$. Toward the northern part of the high water-level area, the temperature of pumped water from well 4358-01 is about $23{ }^{\circ} \mathrm{C}$, and toward the southern part, the temperature of pumped water from well $2753-03$ is about $19^{\circ} \mathrm{C}$. In the Keauhou aquifer system, average air temperatures between about 20 and $22{ }^{\circ} \mathrm{C}$ are estimated to occur mainly between altitudes of about 1,000 and 2,000 ft and average air temperatures between about 18 and $20^{\circ} \mathrm{C}$ are estimated to occur mainly between altitudes of about 2,000 and 3,000 ft (Kagawa-Viviani and Giambelluca, 2020). Salinity and groundwater-temperature variations with depth are largely unknown in the high water-level area.

\section{Conceptual Model of Groundwater Flow}

The three main groundwater bodies in the study area are (1) the coastal freshwater-lens system, (2) the deep coastal confined-groundwater system, and (3) the inland groundwater body with high water levels (fig. 6). Groundwater from the deep coastal confined-groundwater system and inland high waterlevel area may discharge into the coastal freshwater-lens system. The fresh and brackish groundwater in the coastal freshwaterlens system discharges to wells, the ocean, and ponds and pools, or is transpired by vegetation with roots that extend to groundwater. Groundwater that discharges to the fishponds and pools discharges back to the aquifer, discharges directly to the ocean (in the case of Kaloko fishpond), or evaporates. 
Within the coastal freshwater-lens system, the freshwater component of groundwater generally flows from inland areas to the ocean (fig. 11). This general flow pattern may be modified by geologic structures, groundwater withdrawals, wastewater disposal, or ocean tides. A saltwater circulation system exists beneath the fresh and brackish water of the coastal lens. Saltwater enters the aquifer from the ocean, beneath the zone of fresh and brackish groundwater discharge from the coastal lens. The flow path of saltwater in the aquifer is dependent on the depth of inflow of the saltwater. The warmest and shallowest saltwater from the ocean is expected to have the shortest flow path: (1) saltwater enters the aquifer
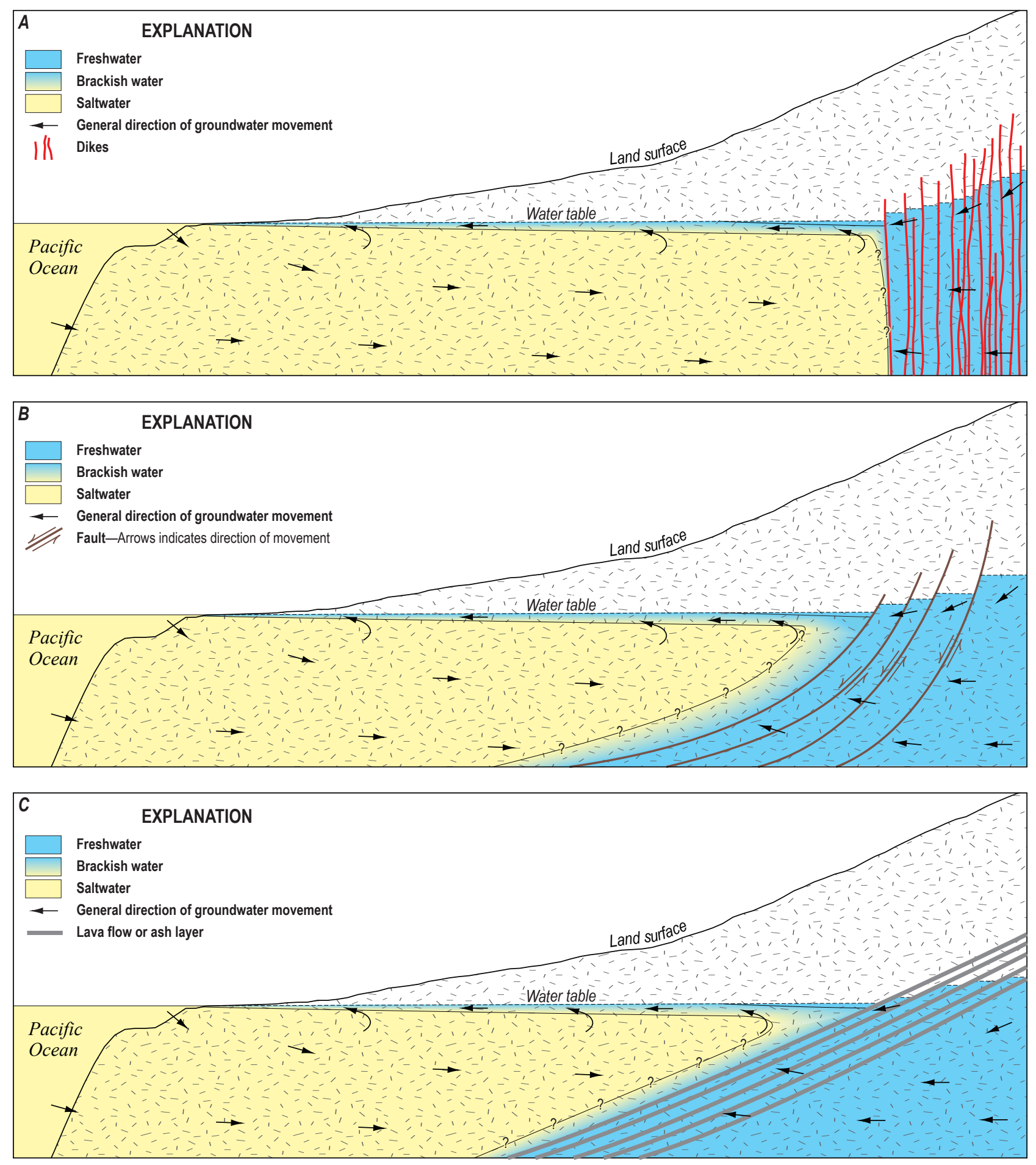

Figure 13. Schematic cross sections showing possible geologic structures that may impound groundwater to high levels in the inland part of the Keauhou area, Hawaili: $A$, buried dikes; $B$, buried fault system; $C$, buried low-permeability lava flows or ash layers. Modified from Oki (1999). 
immediately beneath the zone of brackish-water discharge to the ocean, (2) flows landward, (3) rises and becomes entrained with the seaward flowing brackish water, and (4) returns to the ocean. The coldest and deepest saltwater from the ocean is expected to have the longest flow path: (1) cold saltwater enters the aquifer at depth, well below the zone of brackishwater discharge to the ocean; (2) flows landward; (3) rises near the inland extent of the coastal lens; (4) mixes with seaward flowing freshwater, creating a brackish water zone; and (5) discharges to the ocean within the zone of fresh and brackish groundwater discharge from the coastal lens.

Limited available data indicate that a zone of confined groundwater exists beneath the coastal freshwater-lens system, at least in parts of the Keauhou aquifer system. The freshwater component of groundwater in the deep coastal confinedgroundwater system is derived from groundwater discharge from the inland high water-level area. The confined groundwater discharges upward to the overlying coastal freshwaterlens system, directly to the ocean, or both. Available salinity profiles from the Kamakana well (3959-01) indicate a very gradual increase in salinity from the water table to an altitude of about $-500 \mathrm{ft}$ (fig. 12), which may reflect upward discharge of water from the deep coastal confined-groundwater system or deep discharge of freshwater from the inland area with high water levels.

The geometry and permeability of the confining unit (or units) controls the distribution of discharge from the deep coastal confined-groundwater system (fig. 6). A confining unit may be formed by a low-permeability lava flow, ash layer, fault, or weathered erosional surface. If the confining units extend to and crop out at the ocean bottom and are of sufficiently low permeability, then groundwater from the deep confined-groundwater system may discharge directly to the ocean (fig. $6 A$ ). Alternatively, if the confining units extend to the ocean but are not of sufficiently low permeability, then groundwater from the deep confined-groundwater system may discharge entirely within the aquifer, with no confined groundwater discharging directly to the ocean (fig. $6 B$ ). If the confining units terminate within the aquifer rather than crop out at the ocean bottom, then groundwater from the deep confined-groundwater system will discharge entirely within the aquifer, with no confined groundwater discharging directly to the ocean (fig. 6C).

Recent information from offshore controlled-source electromagnetic geophysical surveys indicates the presence of submarine groundwater discharge off parts of the west coast of Hawai' $i$ (Attias and others, 2020). The presence of offshore groundwater with salinity lower than that of ocean water was inferred from electrical-resistivity anomalies at depths ranging from about 300 to $1,600 \mathrm{ft}$ below sea level, extending to as much as $13,000 \mathrm{ft}$ offshore in places. The presence of deep offshore discharge of groundwater is consistent with information available from deep monitor wells in the Keauhou aquifer system that indicate the presence of a deep confinedgroundwater system.
Inland from the coastal freshwater-lens system, water levels are impounded to high levels (in excess of a few tens of feet above sea level) by a geologic structure of unknown origin. The geologic structure may be related to buried dikes, faults, or low-permeability lava flows or ash layers. An aquifer test indicated several boundaries present near the test site, which is south of the Keauhou aquifer system (Oki, 1999), and this interpretation is consistent with a compartmentalized aquifer commonly found in dike-impounded groundwater systems. The impounded groundwater that is not withdrawn by wells discharges to the downgradient coastal confined-groundwater system. In addition, impounded groundwater discharges directly to the coastal freshwater-lens system. Stable isotopes of water from the inland high water-level area and the coastal freshwater-lens system indicate that a component of the inland, impounded groundwater is present in the coastal lens system (Tillman and others, 2014; Fackrell, 2016).

\section{Groundwater Discharge Through KAHO}

Groundwater discharge through KAHO consists of brackish water, which is part of the coastal freshwater-lens system. Within KAHO, groundwater is brackish at the water table and salinity increases with depth. No deep wells have been drilled in KAHO to confirm whether confined fresh groundwater flows beneath the coastal freshwater-lens system. The brackish-water resources in KAHO sustain habitat for threatened and endangered native waterbirds and rare endemic anchialine pool species, including the endangered orangeblack Hawaiian damselfly.

The rate of groundwater discharge (freshwater component) through KAHO was previously estimated to be about $3 \mathrm{Mgal} / \mathrm{d}$ per mile of aquifer width (Oki and others, 1999), although this estimate relied on a recharge distribution determined from a simplified water-budget analysis. A more detailed water-budget analysis (Engott, 2011) indicated total recharge inland from KAHO to average about $6.5 \mathrm{Mgal} / \mathrm{d}$ per mile of aquifer width, although it is possible that some of this water may discharge directly to the ocean from a confined coastal-groundwater system, beneath the coastal freshwater-lens system. In addition, some of the groundwater is withdrawn by wells in the high water-level area.

\section{Factors Affecting Groundwater Discharge Through KAHO}

Groundwater discharge through KAHO may be affected by both natural and anthropogenic factors. Long-term changes in future rainfall will affect groundwater recharge, which will affect groundwater discharge through KAHO. Elison Timm and others $(2013,2015)$ used statistical downscaling methods and projected future declines in rainfall during the 21 st century. Using medium and high emission scenarios for atmospheric greenhouse gases, Elison Timm and others (2013, 2015) projected rainfall declines exceeding 25 percent by 
the end of the 21st century in parts of the study area. Thus, groundwater discharge through KAHO may decrease during the 21st century in response to decreased rainfall and recharge.

Anthropogenic factors that could affect the groundwater discharge through KAHO include groundwater withdrawals and disposal or injection of wastewater. Groundwater withdrawals from the coastal freshwater-lens system, the coastal confined-groundwater system, or the inland high water-level area will reduce the freshwater component of overall discharge to the ocean. How groundwater withdrawals will affect salinity within KAHO will depend on the locations and rates of withdrawals. Groundwater withdrawals from the Keauhou aquifer system generally have increased over time, ranging from less than $6 \mathrm{Mgal} / \mathrm{d}$ during the early 1980 s to greater than $15 \mathrm{Mgal} / \mathrm{d}$ during some months since 2009 (fig. 14). The first reported withdrawal from the inland high water-level area was in 1994. Currently (2020) groundwater is not withdrawn from the deep coastal confined-groundwater system.

In addition to wastewater disposal associated with small, individual septic systems and injection wells in the Kona area, wastewater disposal also is associated with larger-scale systems. For example, about $1.5 \mathrm{Mgal} / \mathrm{d}$ of wastewater from the Hawai'i County Kealakehe Wastewater Treatment Plant is discharged into a pit $0.6 \mathrm{mi}$ southeast from the southeast boundary of KAHO (fig. 2). Other notable discharges near KAHO include (1) about $25 \mathrm{Mgal} / \mathrm{d}$ of saltwater discharged into surface trenches in the Natural Energy Laboratory of Hawaii Authority (NELHA) facility near Keahole Point, (2) about $0.4 \mathrm{Mgal} / \mathrm{d}$ of reverse-osmosis concentrate discharged into an injection well between altitudes of about -96 and $-116 \mathrm{ft}$ about $0.5 \mathrm{mi}$ north of KAHO, and (3) about 0.04
$\mathrm{Mgal} / \mathrm{d}$ of process wastewater discharged into injection wells between altitudes of about -264 and $-314 \mathrm{ft}$ at a powergenerating facility about $3 \mathrm{mi}$ north of KAHO.

\section{Simulation of Groundwater Flow}

Numerical models are useful for understanding groundwater flow systems and have been used to simulate groundwater flow in the Kona area. Existing models include two-dimensional flow models of freshwater flow (Water Resource Associates, 2007) and freshwater-saltwater flow in which the interface between freshwater and saltwater is considered a sharp interface (Oki and others, 1999). Models developed for this study are capable of simulating the brackish-water transition zone that exists in coastal aquifers. The model code used for this study was SUTRA (ver. 2.2) and SUTRA-MS (ver. 1.1) (Hughes and Sanford, 2004; Voss and Provost, 2010). SUTRA is a finite-element code that simulates fluid movement and the transport of dissolved substances in a groundwater system. SUTRA is capable of simulating threedimensional, variable-density groundwater flow and solute (single species) or heat transport in heterogeneous anisotropic aquifers. SUTRA-MS adds the capability to simulate more than one solute and heat transport simultaneously and was used in this study for cross-sectional models.

Two types of models were developed for this study: (1) two-dimensional cross-section models that simulate salinity and heat transport, and (2) three-dimensional models that simulate salinity transport (Oki, 2021). The two-dimensional cross-section models were used mainly to evaluate conceptual models of the flow system and estimate hydraulic

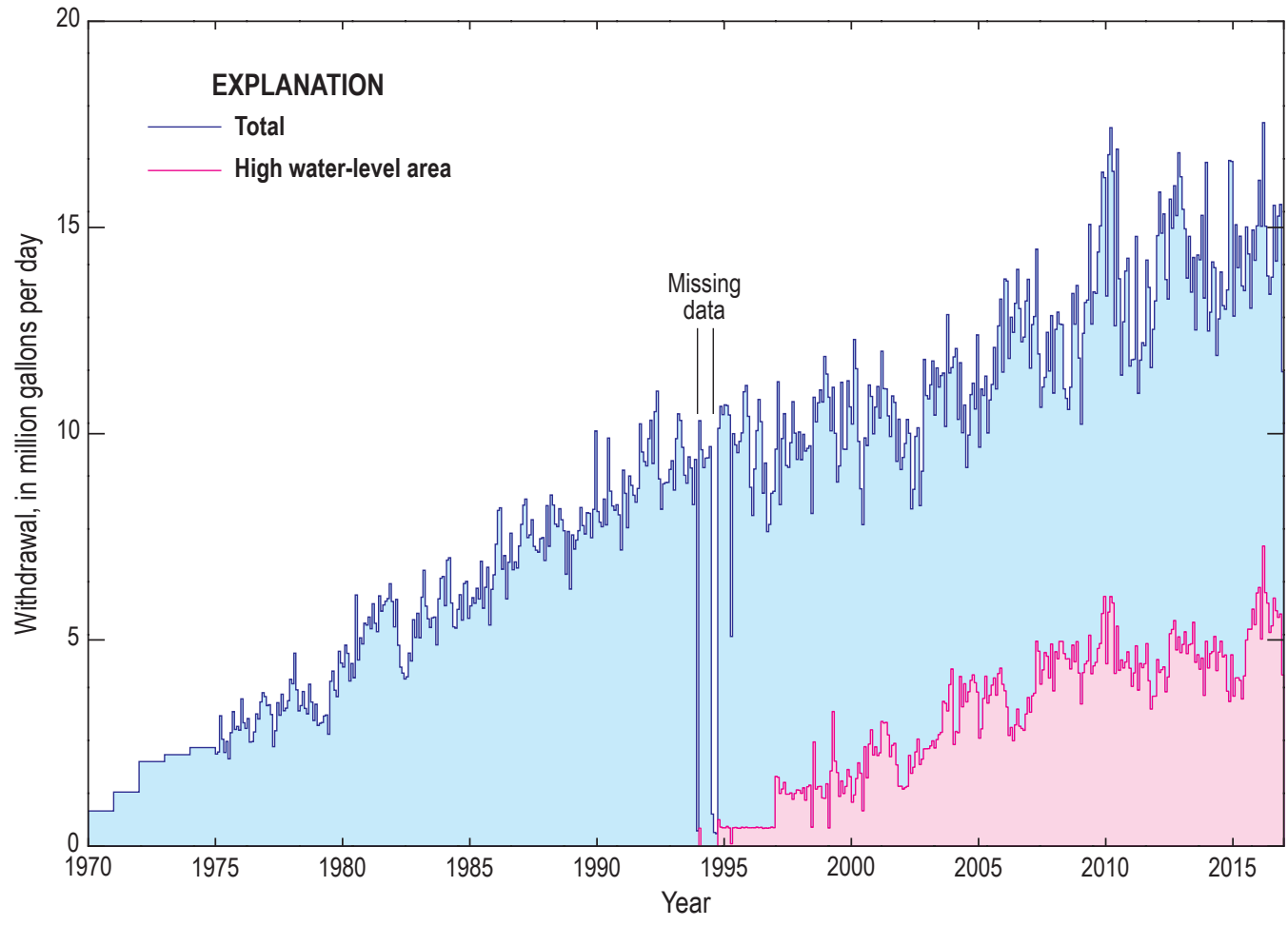

Figure 14. Graph showing groundwater withdrawals during the period 1970 through 2016 in the State Keauhou aquifer system, Hawaili. Reported withdrawals from Oki and others (1999) and Robert Chenet, Hawai'i Commission on Water Resource Management, written commun. (2018). 
characteristics, and the three-dimensional models were used to evaluate potential changes in groundwater salinity in $\mathrm{KAHO}$ associated with selected withdrawal or injection rates. Hydraulic-characteristic values were varied in the crosssection models to obtain general agreement between simulated and measured water levels, salinity variations with depth, and temperature variations with depth. All models assumed a gravity value of 32.12 feet per square second $\left(\mathrm{ft} / \mathrm{s}^{2} ; 9.79\right.$ meters per square second $\left[\mathrm{m} / \mathrm{s}^{2}\right]$ ), zero production or decay of solute, and no solute adsorption. All models were run to steady-state conditions, although short-term transient simulations also were run using the two-dimensional cross-section models to evaluate groundwater-level variations related to ocean tides.

\section{Water Properties}

For all numerical models, water was assigned a fluid compressibility of $2.14 \times 10^{-8}$ square feet per pound $\left(\mathrm{ft}^{2} / \mathrm{lb}\right.$; $4.47 \times 10^{-10}$ per Pascal $\left.\left[\mathrm{Pa}^{-1}\right]\right)$, and molecular diffusivity was assigned a value of $1.1 \times 10^{-8}$ square feet per second $\left(\mathrm{ft}^{2} / \mathrm{s}\right.$; $1.0 \times 10^{-9}$ square meters per second $\left.\left[\mathrm{m}^{2} / \mathrm{s}\right]\right)$. Solute concentrations in the model are expressed as a mass fraction: mass of total dissolved solids (TDS) per unit mass of fluid. Pure freshwater was assigned a TDS concentration of zero and 100 percent saltwater (ocean water) was assigned a TDS concentration of 0.0357 kilograms per kilogram $(\mathrm{kg} / \mathrm{kg})$.

Water density was assumed to be a linear function of salinity, and for models simulating heat transport, a function of temperature, according to the following relation:

$$
\rho=\rho_{0}+\mathrm{d} \rho / \mathrm{d} C \times\left(C-C_{0}\right)+\tau \times \mathrm{d} \rho / \mathrm{d} T \times\left(T-T_{0}\right)
$$

$$
\begin{aligned}
& \text { where } \\
& \rho= \\
& \rho_{0}=
\end{aligned}
$$$$
\text { water density }\left(\mathrm{kg} / \mathrm{m}^{3}\right) \text {, }
$$$$
\text { water density at reference total dissolved }
$$$$
\text { solids concentration and }
$$$$
\text { temperature }\left(\mathrm{kg} / \mathrm{m}^{3}\right) \text {, }
$$$$
C=\quad \text { total dissolved solids concentration }(\mathrm{kg} / \mathrm{kg}) \text {, }
$$$$
C_{0}=\quad \text { reference total dissolved solids }
$$$$
\text { concentration }(\mathrm{kg} / \mathrm{kg}) \text {, }
$$$$
T=\quad \text { water temperature }\left({ }^{\circ} \mathrm{C}\right) \text {, }
$$$$
T_{0}=\quad \text { reference water temperature }\left({ }^{\circ} \mathrm{C}\right) \text {, and }
$$$$
\tau=\quad 1 \text { if heat transport is simulated and } \tau=0
$$$$
\text { otherwise. }
$$

The reference values for $\rho_{0}, C_{0}$, and $T_{0}$ were 62.32 pounds per cubic foot $\left(\mathrm{lb} / \mathrm{ft}^{3} ; 998.23\right.$ kilograms per cubic meter $\left.\left[\mathrm{kg} / \mathrm{m}^{3}\right]\right), 0 \mathrm{~kg} / \mathrm{kg}$, and $20^{\circ} \mathrm{C}$, respectively. The rate of change of density as a function of TDS concentration $\left(\mathrm{d} \rho / \mathrm{d} C\right.$ ) was assigned a value of $736.1 \mathrm{~kg} / \mathrm{m}^{3}$ per $\mathrm{kg} / \mathrm{kg}$. For model simulations without heat transport $(\tau=0)$, the density of water increases linearly with salinity from $62.32 \mathrm{lb} / \mathrm{ft}^{3}$ $\left(998.23 \mathrm{~kg} / \mathrm{m}^{3}\right)$ for freshwater to $63.96 \mathrm{lb} / \mathrm{ft}^{3}\left(1,024.51 \mathrm{~kg} / \mathrm{m}^{3}\right)$ for ocean water. The rate of change of density as a function of temperature $(\mathrm{d} \rho / \mathrm{d} T)$ was assigned a value of $-0.127 \mathrm{~kg} / \mathrm{m}^{3}$ per ${ }^{\circ} \mathrm{C}$. The density model used for this study results in (1) water densities that are within 0.2 percent of those from
Sharqawy and others (2010, eq. 8) for salinities ranging from freshwater to saltwater and temperatures between 4 and $30{ }^{\circ} \mathrm{C}$, and (2) a specific gravity of 1.0263 at $22{ }^{\circ} \mathrm{C}$ for ocean water (Wentworth, 1939).

For heat-transport models, fluid specific heat was assigned a value of 4,150 Joules per kilogram per degree Celsius ( $\mathrm{J} / \mathrm{kg}$ per $\left.{ }^{\circ} \mathrm{C}\right)$. SUTRA-MS assumes fluid specific heat is a constant, although fluid specific heat does vary slightly within the range of temperatures and salinities simulated in this study (Millero and others, 1973; Sun and others, 2008). Fluid thermal conductivity also varies as a function of temperature, pressure, and salinity but was assigned a constant value as required by SUTRA-MS. A fluid thermal-conductivity value of 0.6 Joules per meter per second per degree Celsius $\left(\mathrm{J} / \mathrm{m} \cdot \mathrm{s}\right.$ per $\left.{ }^{\circ} \mathrm{C}\right)$ (Ramires and others, 1995) was assigned in the model.

Fluid dynamic viscosity was assumed to be a function of temperature according to the relation (Hughes and Sanford, 2004)

$$
\mu=\left(239.4 \times 10^{-7}\right) 10^{[248.37 /(T+133.15)]}
$$

where

$\mu=\quad$ fluid dynamic viscosity $(\mathrm{kg} / \mathrm{m} \cdot \mathrm{s})$, and

$T=$ fluid temperature $\left({ }^{\circ} \mathrm{C}\right)$.

For model simulations without heat transport $(\tau=0)$, fluid dynamic viscosity was assigned a value of $0.001 \mathrm{~kg} / \mathrm{m} \cdot \mathrm{s}$.

\section{Rock Properties}

For this study, rock properties generally were assigned values based on published estimates or model calibration. Solid-matrix compressibility was assigned a value of $1.2 \times 10^{-7} \mathrm{ft}^{2} / \mathrm{lb}\left(2.5 \times 10^{-9} \mathrm{~Pa}^{-1}\right)$ (Souza and Voss, 1987). The density of the solid rock material was assigned a value of 184 $\mathrm{lb} / \mathrm{ft}^{3}\left(2,950 \mathrm{~kg} / \mathrm{m}^{3}\right)$, which is consistent with measurements from Hawaiian basalt (Robertson and Peck, 1974; Johnson, 1980). The specific heat of the solid rock material was assigned a value of $900 \mathrm{~J} / \mathrm{kg}$ per ${ }^{\circ} \mathrm{C}$ (Roy and others, 1989) and thermal conductivity was assigned a value of $1.82 \mathrm{~J} / \mathrm{m} \cdot \mathrm{s}$ per ${ }^{\circ} \mathrm{C}$ (Horai, 1991). Because of a paucity of data, all rock units represented in the model were assigned the same properties for solid-matrix compressibility, density, specific heat, and thermal conductivity.

Hydraulic conductivity and permeability are quantitative measures of the capacity of a rock to transmit water. The term "permeability" is also commonly used to indicate the ease of fluid movement through a porous rock in a qualitative sense (see Domenico and Schwartz, 1990). The permeability of volcanic rocks varies with a number of factors, including the presence of clinker zones, voids, fractures, and lava tubes; the extent of weathering; and the mode of emplacement. Permeability is a property of the porous medium, whereas hydraulic conductivity also depends on the fluid properties. Hydraulic conductivity is related to permeability, which is the parameter used by both SUTRA and SUTRA-MS, according to the following equation: 


\begin{tabular}{|c|c|}
\hline \multicolumn{2}{|r|}{$K=k \rho g / \mu$} \\
\hline where & \\
\hline$K$ & $\begin{array}{l}\text { is hydraulic conductivity in units of length } \\
\text { per unit time }\left(\mathrm{LT}^{-1}\right) \text {, }\end{array}$ \\
\hline$k$ & is permeability in units of length squared $\left(\mathrm{L}^{2}\right)$, \\
\hline$\rho$ & $\begin{array}{l}\text { is fluid density in units of mass per unit } \\
\text { length cubed }\left(\mathrm{ML}^{-3}\right) \text {, }\end{array}$ \\
\hline g & $\begin{array}{l}\text { is gravitational acceleration in units of } \\
\text { length per unit time squared }\left(\mathrm{LT}^{-2}\right) \text {, and }\end{array}$ \\
\hline$\mu$ & $\begin{array}{l}\text { is fluid dynamic viscosity in units of mass } \\
\text { per unit length per unit time }\left(\mathrm{ML}^{-1} \mathrm{~T}^{-1}\right) \text {, } \\
\text { or force-time per unit area. }\end{array}$ \\
\hline
\end{tabular}

\section{Unsaturated Zone}

For this study, a truncated version of the unsaturated zone was represented in the models to account for the water table. The top boundary of the model was at an altitude high enough to enable representation of unconfined, water-table conditions in the coastal freshwater-lens system. The unsaturated-zone characteristics were represented using simple piecewiselinear relations between water saturation and pressure, and between water saturation and relative permeability. Voss (1999) indicates that the details of the unsaturated zone are not important for tracking the water table and can be simplified using linear relations to reduce the computational effort needed for the variable-density simulation. The simplified saturation-pressure relation is of the form

$$
S=1+\left(P-P_{\text {entry }}\right) \times\left(1-S_{\text {res }}\right) /\left(P_{\text {entry }}-P_{\text {min }}\right)
$$

where

$$
\begin{aligned}
& S \quad \text { is saturation constrained to the range from } \\
& S_{r e s} \text { to } 1 \text { (volume fraction, unitless), } \\
& P \quad \text { is pressure in units of force per unit area } \\
& \left(\mathrm{ML}^{-1} \mathrm{~T}^{-2}\right) \text {, } \\
& P_{\text {entry }} \quad \text { is entry pressure above which } S=1 \text {, } \\
& P_{\text {min }} \quad \text { is minimum pressure below which } S=S_{\text {res }} \text {, } \\
& (-48,863 \mathrm{~Pa})\left(\mathrm{ML}^{-1} \mathrm{~T}^{-2}\right) \text {, and } \\
& S_{\text {res }} \quad \text { is residual saturation, assigned a value } \\
& \text { of } 0.01 \text {. }
\end{aligned}
$$

The simplified saturation-permeability relation is of the form

$$
k_{r e l}=(S-0.01) / 0.99
$$

where

$k_{r e l} \quad$ is relative permeability (a multiplier for permeability), constrained to the range from 0 to 1 (unitless).

\section{Two-Dimensional Cross-Section Model}

The modeled cross section passes through KAHO, is oriented generally perpendicular to the contour lines of equal land-surface altitude, and is designed to be hydrologically and bathymetrically representative of a 5-mi-wide strip, with the modeled section at the center of the 5-mi-wide strip (fig. 8). Recharge (Engott, 2011) within the 5-mi-wide strip was averaged and used as input to the model. Bathymetry (Carignan and others, 2011) for the modeled cross section was determined from the average of the nine inner, parallel, and equally spaced (0.5-mi spacing) cross sections (four to the north of the modeled section, the modeled section, and four to the south of the modeled section) within the 5-mi-wide strip (the two bounding cross sections of the 5-mi-wide strip were not used in computing average bathymetry). In the model, the average bathymetry was further simplified using a piecewise linear representation.

\section{Model Mesh}

The model mesh used for this study consists of 182,030 nodes and 181,135 elements, extends about $4 \mathrm{mi}$ inland to cover the entire coastal freshwater-lens system, and extends about $3 \mathrm{mi}$ offshore to include the zone where freshwater discharges to the ocean and saltwater enters the aquifer (fig. 15). The model mesh excludes most of the impounded groundwater body with high water levels, although a small zone of elevated groundwater levels is included inland of a vertical confining unit in the model and discharge from the impounded groundwater body with high water levels is represented in the model.

The top of the onshore model domain is at an altitude of $6.6 \mathrm{ft}$ to allow representation of unconfined, water-table conditions in the coastal freshwater-lens system. The top of the offshore model domain is defined by the bathymetry. The modeled domain extends 5,906 ft below mean sea level to coincide with an assumed aquifer bottom (Souza and Voss, 1987) and a seismic velocity discontinuity (Furumoto and others, 1970; Kauahikaua, 1993).

Node spacing is variable. Onshore, the horizontal spacing between nodes is $65.6 \mathrm{ft}$; the vertical spacing is about $6.6 \mathrm{ft}$ for the single element above mean sea level, $1.6 \mathrm{ft}$ between mean sea level and an altitude of $-32.8 \mathrm{ft}$, and is a maximum of about $35.0 \mathrm{ft}$ near the bottom of the mesh. Offshore, the horizontal spacing increases from $65.6 \mathrm{ft}$ near the coast to $328.1 \mathrm{ft}$ at the seaward end of the mesh; vertical spacing between nodes is dependent on the bathymetry and ranges from less than $1 \mathrm{ft}$ to about $30 \mathrm{ft}$.

\section{Representation of the System}

For modeling purposes, the model domain was divided into hydraulic-conductivity zones that represent the dikefree volcanic rocks; low-permeability confining units (upper and lower confining units of the deep coastal confinedgroundwater system; a vertical confining unit that separates the coastal freshwater-lens system and inland high water-level area, which also is a vertical extension of and continuous with the upper confining unit of the deep coastal confinedgroundwater system); and offshore sedimentary deposits that overlie the volcanic rocks (fig. 15). The upper and lower 


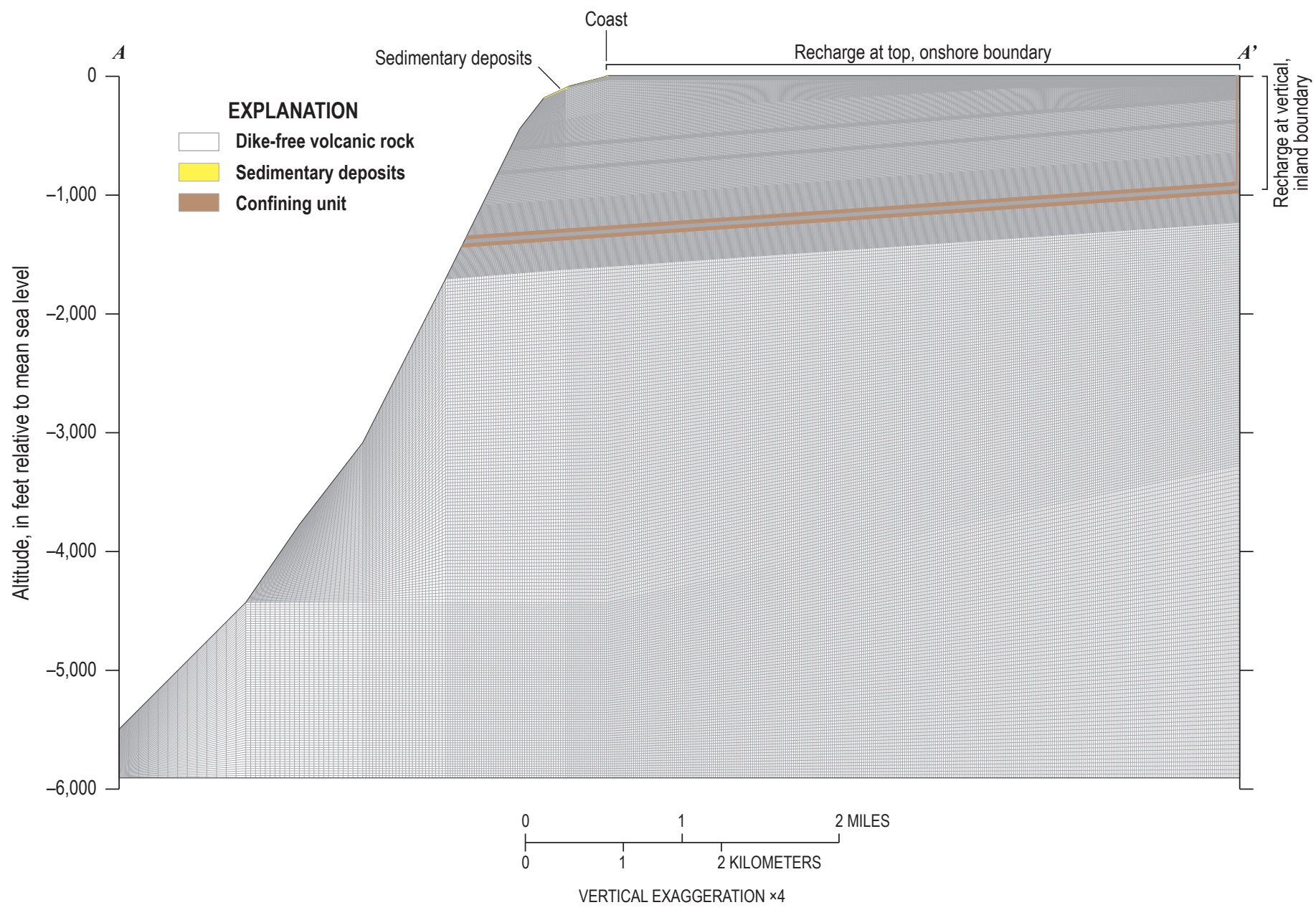

Figure 15. Vertical cross section of the two-dimensional model mesh that represents the area near Kaloko-Honokōhau National Historical Park, Hawai'i (see fig. 8 for location of section A-A).

confining units of the deep coastal confined-groundwater system are represented in the model as 33-ft (10-m) thick units that are above and below a 33-ft-thick confined unit.

\section{Boundary Conditions}

Boundary conditions were specified to account for fluid, solute, and heat fluxes around the perimeter of the model cross section. The vertical sides of the cross section in the plane of the section are fluid, solute, and heat no-flow boundaries. The bottom boundary of the model is a fluid and solute no-flow boundary, although the bottom boundary is a heat-flux boundary. Groundwater recharge enters the model at the top, onshore boundary and the upper $951 \mathrm{ft}$ of the inland vertical boundary of the model. Groundwater discharge from and saltwater inflow to the aquifer may occur at the offshore, ocean-bottom boundary of the model.

\section{Specified Pressure}

The ocean-bottom and vertical offshore boundaries are specified-pressure boundary conditions (hydrostatic ocean-water conditions). The pressure at each node on the ocean-bottom and vertical offshore boundary was set equal to the pressure of a column of ocean water extending from the node to sea level. Because density is a function of temperature and ocean temperature varies with depth (see section on "Specified Temperature"), density is also a function of depth. Specified pressures were computed in a manner consistent with the temperature-dependent density variation with depth. Water may enter or exit the aquifer at specified-pressure nodes. Water entering the aquifer has salinity equal to that of ocean water and temperature representative of ocean water at the depth of the node; water exiting the aquifer has salinity and temperature equal to that in the adjacent aquifer.

\section{Specified Temperature}

The ocean-bottom and vertical offshore boundaries are also modeled as specified-temperature boundary conditions. The temperature at each node on the ocean-bottom and vertical offshore boundary was set equal to the temperature of the ocean water at the depth of the node. For the model, the average ocean-temperature profile was generalized using the average ocean-temperature profile from station ALOHA (fig. 5). 


\section{Heat Flux}

A specified heat-flux boundary was modeled along the entire bottom of the mesh. A heat flux of $0.03276 \mathrm{~J} / \mathrm{m}^{2} \cdot \mathrm{s}$ was assigned along the bottom boundary to represent a geothermal heat source. The heat flux was estimated from the product of the volcanic-rock thermal conductivity and the thermal gradient. Horai (1991) estimated the thermal conductivity of Hawaiian basalt to be $1.82 \mathrm{~J} / \mathrm{m} \cdot \mathrm{s}$ per ${ }^{\circ} \mathrm{C}$ and this value was used to compute the heat flux. Although a lower thermalconductivity value that accounts for fluid in the pores could be used, uncertainty in the thermal gradient in the study area likely exceeds the uncertainty in the thermal-conductivity value used. A thermal gradient of $29.0^{\circ} \mathrm{C}$ per mi $\left(18^{\circ} \mathrm{C}\right.$ per $\mathrm{km}$ ) was assumed for the study area on the basis of limited information from deep wells in eastern Hawai' $i$ (Büttner and Huenges, 2003) and southern O'ahu (Glenn Oyama, Honolulu Board of Water Supply, written commun., 2010).

\section{Recharge and Withdrawal}

Recharge enters the model along the top, onshore watertable boundary and along the inland vertical boundary between altitudes of 0 and $-951 \mathrm{ft}$, which represents the range of depths at the boundary above the deep coastal confined groundwater. Modeled recharge along the top onshore boundary (except at the two most inland nodes) directly enters the coastal freshwater-lens system. Modeled recharge along the top onshore boundary at the two most inland nodes and along the inland vertical boundary directly enters the truncated inland high water-level area, which is connected to the coastal confinedgroundwater system.

Baseline recharge for the Kona area that is representative of average rainfall conditions during 1984-2008 (Engott, 2011) was used in the model. Recharge within the 5-mi-wide strip in the Keauhou aquifer system was averaged in six separate zones, normalized to a unit width $(1 \mathrm{~m})$, and used as input to the cross-section model (fig. 8). Total recharge in the five zones over the coastal freshwater-lens system at the top onshore boundary was $3.47 \mathrm{Mgal} / \mathrm{d}$ per mile of cross-section width and ranged from $20.1 \mathrm{in} / \mathrm{yr}$ (inland zone) to $10.8 \mathrm{in} / \mathrm{yr}$ (coastal zone) (fig. 8). For the zone inland from the boundary separating the coastal freshwater-lens system and inland high water-level area, recharge was $3.07 \mathrm{Mgal} / \mathrm{d}$ per mile of crosssection width $(15.2 \mathrm{in} / \mathrm{yr})$, and was reduced by $0.6 \mathrm{Mgal} / \mathrm{d}$ per mile to account for average 2009-13 groundwater withdrawals from the inland high water-level area. The temperature of water entering the aquifer at specified-flux (recharge) nodes was assigned a value of $21^{\circ} \mathrm{C}$, which is consistent with measured temperatures from wells in the inland high waterlevel area. The salinity of water entering at recharge nodes was assigned a value of 0.1 percent that of ocean water, which is generally consistent with salinity of water from pumped wells in the inland high water-level area.

\section{Estimation of Aquifer Hydraulic Properties}

Hydraulic-conductivity and effective-porosity values were estimated by trial and error in the cross-section models to obtain general agreement between simulated and measured water levels that vary spatially and temporally, salinity variations with depth, and temperature variations with depth. Available information indicates a highly permeable aquifer through which the hydrologic effects of ocean tides on groundwater levels can efficiently propagate inland in the coastal freshwater-lens system. Available information also indicates a zone of confined fresh groundwater that exists beneath the coastal freshwater-lens system. Effective porosity was estimated to be 0.07 for all zones except the deep coastal confined-groundwater body for which effective porosity was assigned a value of 0.03 . Limited available water-level data from January 5, 2011, indicate a high tidal efficiency in the deep coastal confinedgroundwater body (Tom Nance, Tom Nance Water Resource Engineering, written commun., 2012). The effective porosity of the deep coastal confined-groundwater body was assigned a value of 0.03 to reflect a high tidal efficiency, although the simulated tidal efficiency was not effectively increased. To increase the simulated tidal efficiency within the confined zone, the more appropriate parameter to adjust is the solidmatrix compressibility, but this parameter could not be varied spatially in the model.

For the cross-sectional model, the direction of maximum hydraulic conductivity for the dike-free volcanic rocks is assumed to dip from the horizontal and the maximum hydraulic conductivity is referred to as the "horizontal hydraulic conductivity." The dip of the dike-free volcanic rocks was assumed to be spatially variable with the following characteristics: (1) $1^{\circ}$ for the deep coastal confined-groundwater system and associated confining units; (2) $5^{\circ}$ below the deep coastal confined-groundwater system; (3) from about $0^{\circ}$ to $3.5^{\circ}$ (determined by linearly interpolating in a vertical direction the dip of the land surface to the dip of the upper confining unit of the deep coastal confined-groundwater system) for the onshore coastal freshwater-lens system above the deep coastal confined-groundwater system; and (4) from about $0^{\circ}$ to $1^{\circ}$ (determined by linearly interpolating in a vertical direction the dip from the land surface at the coast to the upper confining unit of the deep coastal confined-groundwater system) for the offshore coastal freshwater-lens system above the deep coastal confined-groundwater system. The dips of the low-permeability confining units and sedimentary deposits were assigned the same values as the nearby dike-free volcanic rocks, but this does not affect model results because these units were assumed to be isotropic.

Estimated horizontal hydraulic-conductivity values were $12,000 \mathrm{ft} / \mathrm{d}$ for the dike-free volcanic rocks; 0.002 and 0.00001 $\mathrm{ft} / \mathrm{d}$ for the upper and lower confining units of the deep coastal confined-groundwater system; $0.0075 \mathrm{ft} / \mathrm{d}$ for the vertical 
extension of the upper confining unit; and $2 \mathrm{ft} / \mathrm{d}$ for the thin (one-element thick) offshore sedimentary deposits represented in the model above an altitude of about $-180 \mathrm{ft}$. The hydraulic conductivity values are partly a function of the thickness of the units represented in the model and may not be unique. Vertical anisotropy (ratio of horizontal-to-vertical hydraulic conductivity) was 50:1 for the dike-free volcanic rocks and 1:1 (isotropic) for sedimentary deposits and confining units.

For two-dimensional cross-section, solute-transport simulation, SUTRA-MS requires specification of two longitudinal-dispersivity values and two transversedispersivity values. Longitudinal-dispersivity values used in the model were $250 \mathrm{ft}$ and $5 \mathrm{ft}$ in directions of maximum (horizontal longitudinal) hydraulic conductivity and minimum (vertical) hydraulic conductivity, respectively. Transversedispersivity values used in the model were $0.16 \mathrm{ft}$ in both directions (maximum hydraulic conductivity and minimum hydraulic conductivity).

\section{Simulation Results}

Simulated salinity and temperature profiles at a distance of $2.6 \mathrm{mi}(4,200 \mathrm{~m})$ from the coast were compared to composite salinity and temperature profiles from the Kamakana well (3959-01) (fig. 16). The simulated profiles are generally consistent with the observed profiles. The simulated salinity profile is consistent with the thick, diffuse transition zone of the coastal freshwater-lens system observed in the
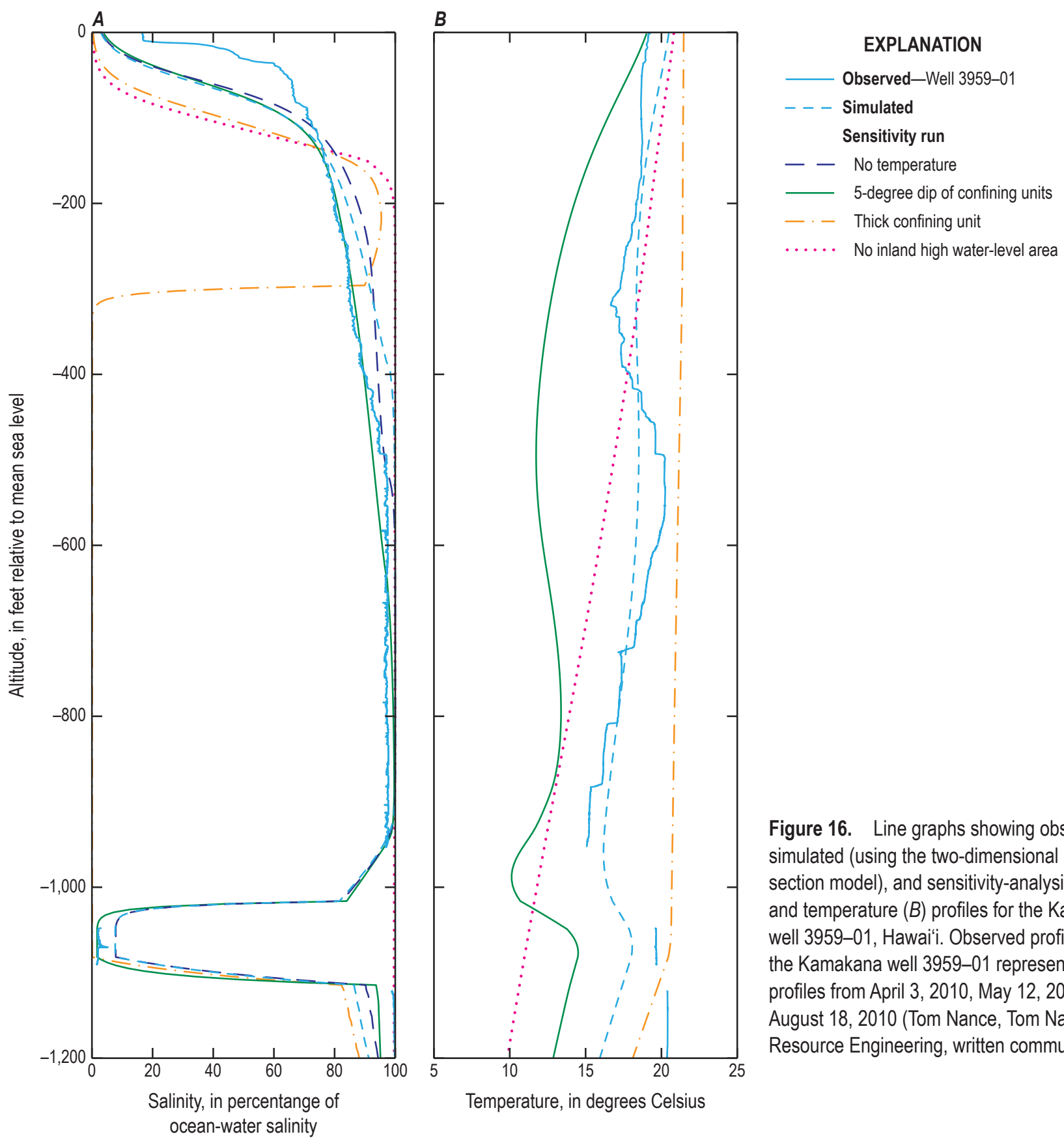

Figure 16. Line graphs showing observed, simulated (using the two-dimensional crosssection model), and sensitivity-analysis salinity $(A)$ and temperature $(B)$ profiles for the Kamakana well 3959-01, Hawai'i. Observed profiles from the Kamakana well 3959-01 represent composite profiles from April 3, 2010, May 12, 2010, and August 18, 2010 (Tom Nance, Tom Nance Water Resource Engineering, written commun., 2012). 
Kamakana well and also is consistent with the presence of freshwater in a deep coastal confined-groundwater system. The simulated temperature profile indicates slight temperature variations with depth that are generally consistent with, but not as large as, the temperature variations observed in the Kamakana well. The temperature variations reflect circulation of cold saltwater from the ocean.

A short-term transient simulation for the period from May 1, 2009, to February 28, 2010, was used to evaluate the model representation of tidal variations of groundwater levels. A time-variant specified-pressure boundary condition was used at the ocean-bottom nodes that is consistent with observed ocean-level variations from National Oceanic and Atmospheric Administration tide gage 1617433 at Kawaihae (fig. 1;

National Oceanic and Atmospheric Administration, 2010). The simulated groundwater levels generally are consistent with the observed spatial and temporal variations in groundwater levels in the modeled area (fig. 17). Groundwater levels increase in an inland direction and the magnitude of tidal-induced variations in groundwater levels decreases in an inland direction.

\section{Sensitivity Analysis}

Results from a limited number of additional cross-section model runs are included in this section to evaluate how salinity and temperature are conceptually affected by the model characteristics. Model characteristics that were tested and included here are (1) exclusion of temperature-related effects on densitydependent solute transport; (2) dip of confining units; (3) presence of a thick, low-permeability unit; and (4) exclusion of confining units and recharge from the inland vertical boundary. For these additional model runs, hydraulic-conductivity values were adjusted as needed to produce a reasonable groundwaterlevel gradient consistent with available information, although the models are not considered calibrated models.

\section{Exclusion of Temperature}

A model simulation using SUTRA was run to evaluate the importance of temperature-related density effects on simulated salinity at the Kamakana well. All other model parameters were not adjusted from the original cross-section model.

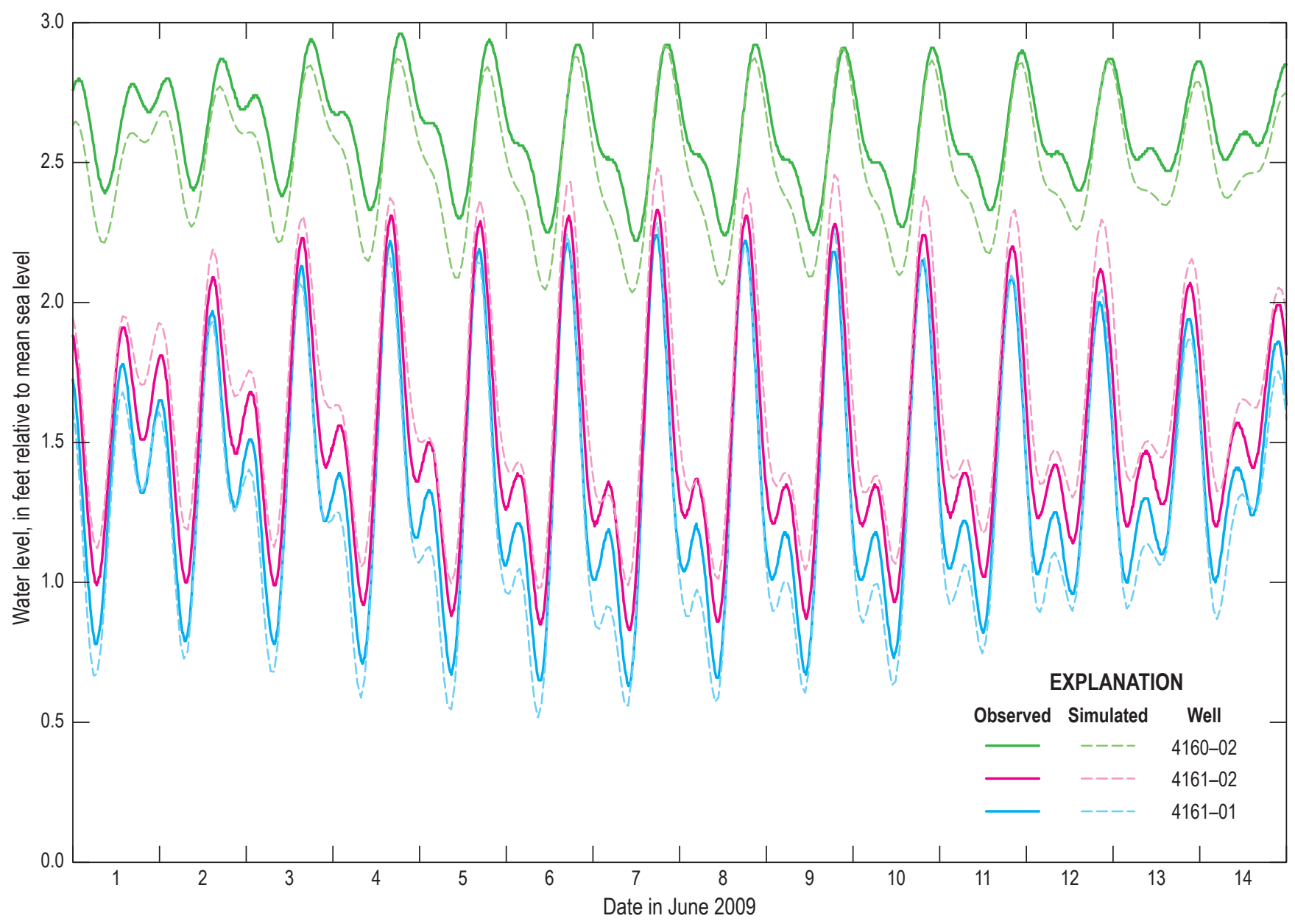

Figure 17. Line graph showing observed and simulated (using the two-dimensional cross-section model) transient groundwater levels for selected wells in, and inland from, Kaloko-Honokōhau National Historical Park, Hawai'i. Observed groundwater-level data from U.S. Geological Survey (2020). 
Results of this simulation indicate that the salinity distributions with and without temperature-related effects are similar (fig. 16). However, inclusion of temperature in the cross-section model is diagnostic in terms of evaluating conceptualizations of the groundwater-flow system, including the dip of the confining units.

\section{Dip of Confining Units}

A model simulation was run to evaluate the importance of the dip of the confining units of the deep coastal confinedgroundwater system. The dip of the confining units in the model was increased from $1^{\circ}$ to $5^{\circ}$ (the mesh was modified slightly to align the confining units with the $5^{\circ} \mathrm{dip}$ ), maintaining the same freshwater-zone depth as indicated in the Kamakana well salinity profile. The hydraulic conductivity of the upper confining unit also was decreased to $0.001 \mathrm{ft} / \mathrm{d}$ (from $0.002 \mathrm{ft} / \mathrm{d}$ in the original cross-section model).

Results of the simulation indicate a simulated salinity profile that is generally consistent with the observed profile (fig. 16). However, the simulated temperature profile indicates colder water than the observed temperature profile (fig. 16). Thus, if the confining units dip at $5^{\circ}$ (rather than $1^{\circ}$ ), then model results indicate increased circulation of cold deep saltwater from the ocean that affects groundwater temperatures. Thus, including temperature in the simulation appears to be diagnostic for evaluating the representativeness of conceptual models.

\section{Presence of Thick Upper Confining Unit}

A model simulation was run to evaluate how the thickness of the upper confining unit of the deep coastal confinedgroundwater system affects simulated salinity and temperature profiles at the Kamakana well. The thickness of the upper confining unit was increased from $33 \mathrm{ft}$ to $755 \mathrm{ft}$ (10 m to $230 \mathrm{~m}$ ) and the confining unit was extended to the inland vertical boundary of the mesh. The hydraulic-conductivity value for the dike-free volcanic rocks also was decreased to $8,000 \mathrm{ft} / \mathrm{d}$ (from $12,000 \mathrm{ft} / \mathrm{d}$ in the original cross-section model).

Results of the simulation indicate a thick freshwater zone within the upper confining unit that is not consistent with the observed salinity profile from the Kamakana well (fig. 16). Also, the simulated temperature profile indicates water temperatures higher than observed temperatures (fig. 16), which is related to limited circulation of cold ocean water in the coastal freshwater-lens system because of the thick, lowpermeability confining unit.

\section{Exclusion of Confining Units and Recharge from Inland Vertical Boundary}

A model simulation was run to evaluate how the deep coastal confined-groundwater system affects simulated salinity and temperature profiles at the Kamakana well. For this simulation, the confining units and recharge related to the presence of the deep coastal confined-groundwater system were excluded from the cross-section model. The confining units were assigned the same properties as the aquifer for this simulation.

In the absence of a deep coastal confined-groundwater system, model results indicate a relatively thin and sharp brackish-water transition zone, which is not consistent with the observed salinity profile from the Kamakana well (fig. 16). Also, because the confining units were excluded in the model, the model expectedly does not represent the deep confined freshwater. The observed salinity profile from the Kahalu' $u$ deep monitor well also indicates a relatively thin and sharp brackish-water transition zone, which is consistent with the lack of a deep source of fresher water that would tend to create a thicker and more diffuse transition zone. The simulated temperature profile indicates a nearly linear decrease in temperature with depth, which is not consistent with the observed temperature profile from the Kamakana well.

\section{Three-Dimensional Regional Model}

The hydraulic properties of the two-dimensional crosssection model were used to develop a three-dimensional regional model for the northern part of the CWRM-delineated Keauhou aquifer system. Geometry and parameter values used in the cross-section model may differ slightly from those used in the three-dimensional model, although differences generally are minor. The three-dimensional numerical model uses the model code SUTRA and simulates density-dependent salinity transport without considering temperature. The three-dimensional model was used to evaluate changes in groundwater salinity in KAHO associated with selected withdrawal or injection rates.

\section{Model Mesh}

The model mesh used for this study consists of 950,361 nodes and 917,843 elements, covers the coastal freshwaterlens system, and extends more than about $0.5 \mathrm{mi}$ offshore to include the main zones where freshwater discharges to the ocean and saltwater enters the aquifer (figs. 18, 19). Horizontal spacing of nodes is variable and ranges from about 66 to $330 \mathrm{ft}$. The horizontal spacing is finest (1) near the coast, where much of the groundwater discharge from the coastal freshwater-lens system occurs; (2) near the inland boundary of the mesh, where a low permeability zone separates the coastal freshwater-lens system from an inland area with higher water levels; and (3) near existing wells. Horizontal spacing is coarsest near the northwest offshore boundary of the mesh, where groundwater velocities are expected to be low. Vertical spacing of nodes also is variable and ranges from about 1.6 to $35 \mathrm{ft}$. Vertical spacing of nodes is finest near the water table, where salinity increases with depth, and near the low-permeability upper confining unit for the coastal confinedgroundwater system. In the vertical direction, nodes are vertically aligned. 


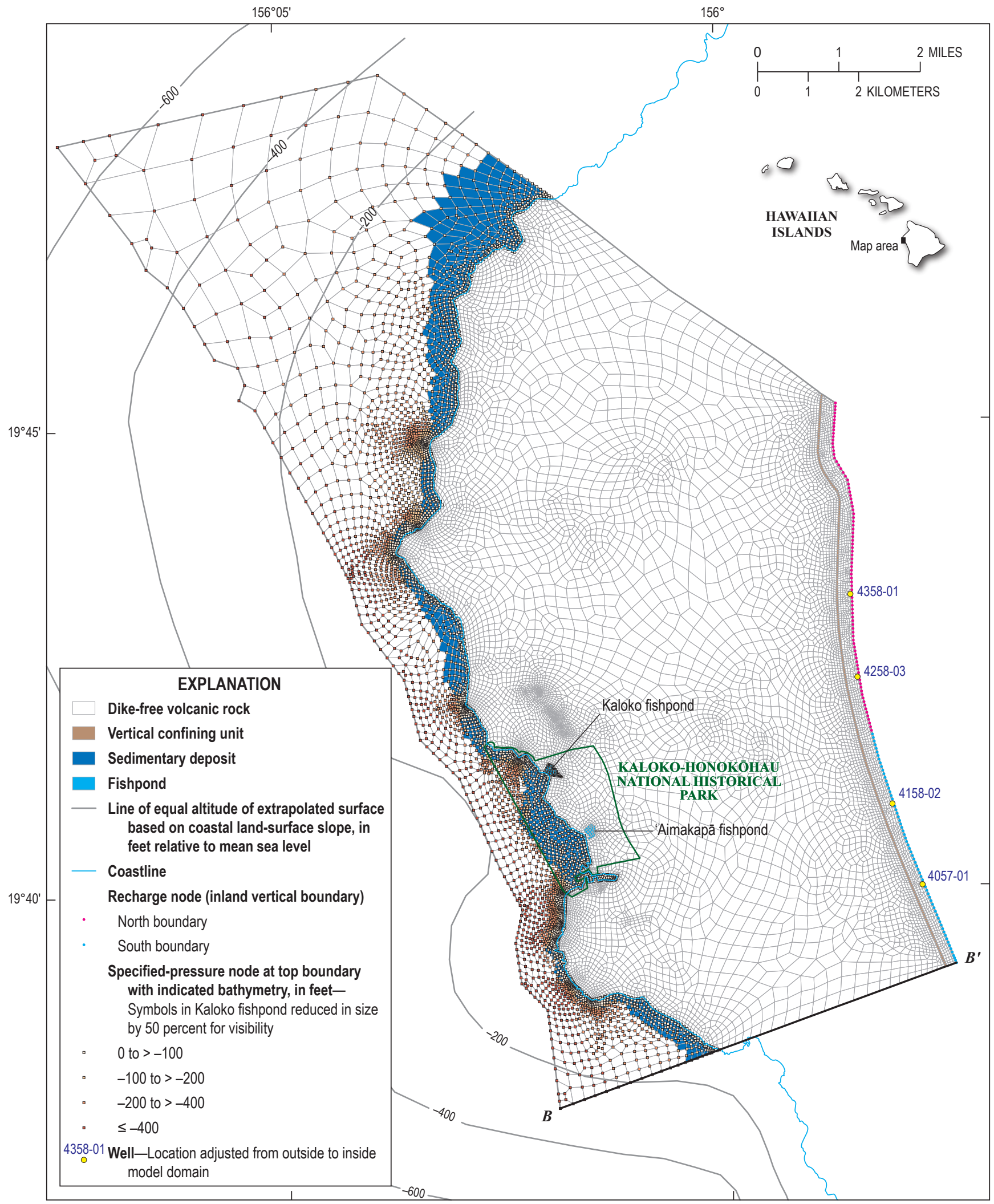

Base modifed from U.S. Geological Survey National Hydrography dataset. Universal Transverse Mercator projection, zone 4,

North American Datum of 1983

Figure 18. Map showing top view of three-dimensional model mesh, zones, and boundary conditions in the Keauhou area, Hawai'i. 


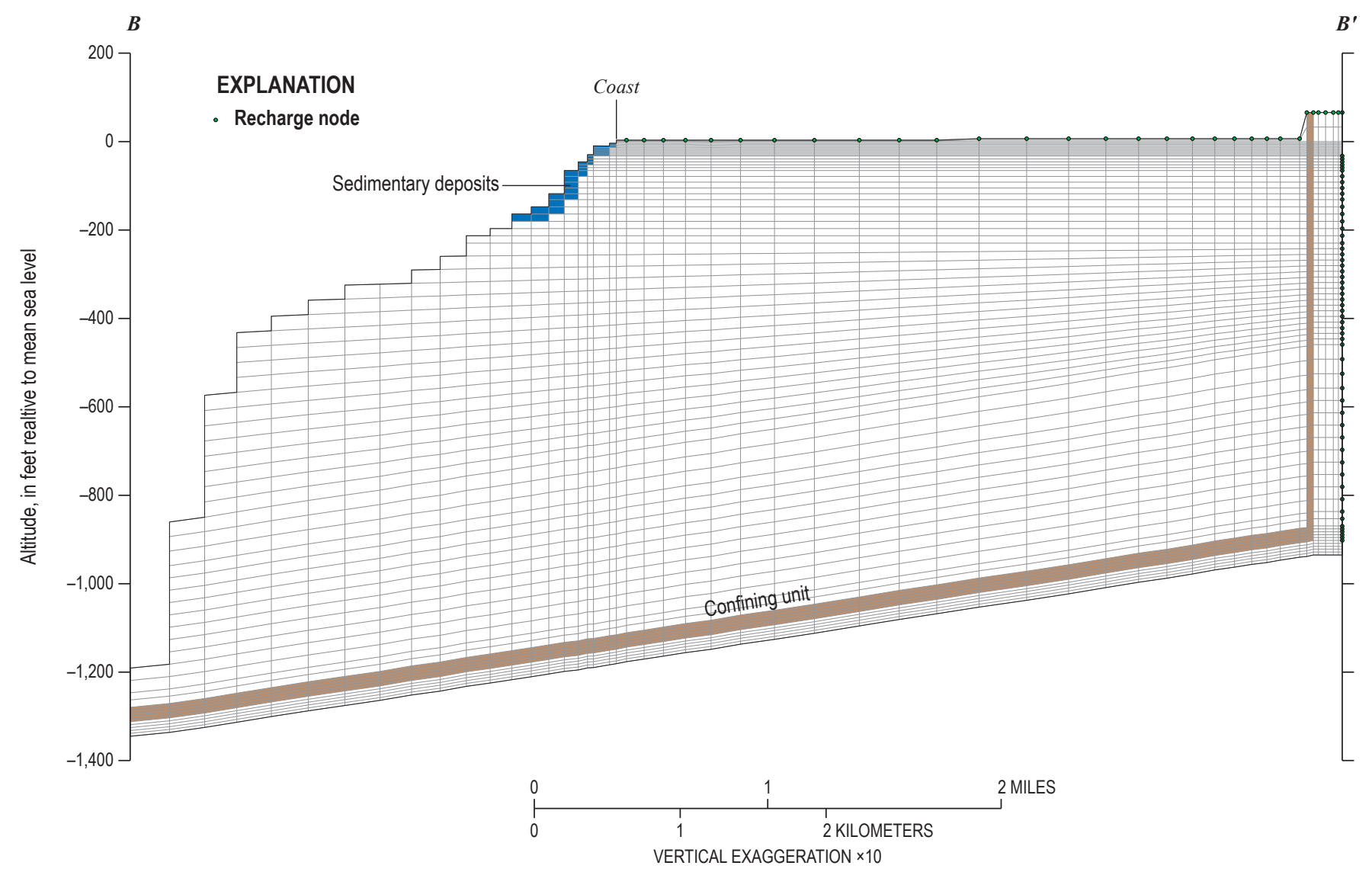

Figure 19. Vertical cross section of the three-dimensional model mesh along section $B-B^{\prime}$ (see fig. 18) on the south boundary of the model domain, Hawai'i.

The offshore western extent of the model domain was defined by the $-1,310$ - $\mathrm{ft}$ bathymetry contour. Because the ocean bathymetry is steep in the modeled area and because the bottom of the model is truncated at the base of the deep coastal confined-groundwater body, the aquifer does not extend far offshore. The model mesh excludes most of the inland groundwater body with high water levels, although a small area of elevated groundwater levels is included inland of a vertical confining unit in the model, and discharge from the inland groundwater body with high water levels is represented in the model. The east boundary of the model is a no-flow boundary, except between altitudes of about -30 to $-900 \mathrm{ft}$, where recharge from the inland part of the Keauhou aquifer system can enter the model domain. The northwest and south boundaries are no-flow boundaries. The northwest boundary coincides with the northwest rift zone of Hualālai volcano, which likely represents a hydrogeological barrier to groundwater flow. The south boundary does not coincide with any known hydrogeological boundary and is generally aligned with the regional groundwater-flow direction. The south boundary of the model was not extended to the south boundary of the Keauhou aquifer system because of uncertainty in hydrogeological conditions and practical computational limitations. The south boundary was located north of the Keopu deep monitor well 2 (3858-02), which indicates the presence of a shallower coastal confined-groundwater system than at the Kamakana well (3959-01), and also north of the Kahalu'u deep monitor well (3457-04), from which salinity profiles may indicate the lack of an underlying coastal confined-groundwater system. The location of the south boundary likely affects model simulations by causing the simulated water-level decline associated with withdrawals to be overestimated, especially for withdrawals near the south boundary.

The top of the modeled domain onshore ranges from altitudes of 3.3 to $66 \mathrm{ft}$ and offshore is defined by the ocean bathymetry. Onshore, the top of the modeled domain is at an altitude of $3.3 \mathrm{ft}$ in the coastal part of the freshwater-lens system and $6.6 \mathrm{ft}$ in the inland part of the freshwater-lens system to allow representation of unconfined, water-table conditions. Inland of the coastal freshwater-lens system the top of the modeled domain is at an altitude of $66 \mathrm{ft}$. The bottom of the modeled domain is defined by the estimated base of the deep coastal confined-groundwater body.

The bottom of the modeled domain deepens in a seaward direction, from an altitude of about $-935 \mathrm{ft}$ (inland end of mesh) to about $-1,345 \mathrm{ft}$ (offshore end of mesh), to coincide 
with the estimated top of the dipping lower confining unit of the deep coastal confined-groundwater system. Thus, the modeled domain includes the deep coastal confined groundwater, which is assumed to be about 33-ft (10-m) thick, is truncated at the base of the coastal confined groundwater, and excludes the lower confining unit.

\section{Representation of the System}

For modeling purposes, a parsimonious representation of the groundwater-flow system was used. The model domain was divided into four main hydraulic-conductivity zones that represent (1) the dike-free volcanic rocks; (2) a low-permeability upper confining unit of the deep coastal confined-groundwater system; (3) a vertical confining unit separating the coastal freshwater-lens system and inland high water-level area, which also is a vertical extension of and continuous with the upper confining unit of the deep coastal confined-groundwater system; and (4) offshore sedimentary deposits that overlie the volcanic rocks (figs. 18, 19). The upper confining unit of the deep coastal confined-groundwater system is represented in the model as a 33-ft-thick unit that overlies a 33-ft-thick confined unit. The sedimentary deposits were limited to altitudes above $-180 \mathrm{ft}$ and were represented by a one-element thick zone.

Kaloko and 'Aimakapā fishponds were explicitly represented in the model. The Kaloko fishpond is represented as a boundary condition, as it is directly connected to the ocean. The 'Aimakapā fishpond, which is not directly connected to the ocean, is represented as a zone of high hydraulic conductivity. Anchialine pools are much smaller features relative to the fishponds and were not explicitly represented in the model. The salinity of selected anchialine pools was represented in the model using the salinity at the nearest node at sea level.

\section{Boundary Conditions}

Boundary conditions were specified to account for fluid and solute fluxes around the perimeter of the model domain. The bottom boundary of the model is a no-flow boundary. Thus, discharge across the lower confining unit of the deep coastal confined-groundwater body is precluded. Groundwater recharge enters the model at the top, onshore boundary and the upper part of the inland vertical boundary of the model. Groundwater discharge from, and saltwater inflow to, the aquifer may occur at the offshore, ocean-bottom boundary of the model.

\section{Specified Pressure}

The ocean-bottom and vertical north offshore boundaries are specified-pressure boundary conditions (hydrostatic oceanwater conditions). Pressure at each node on the ocean-bottom and vertical offshore boundary was set equal to the pressure of a column of ocean water that extends from the node to sea level. Water may enter or exit the aquifer at specified-pressure nodes. Water entering the aquifer has a salinity equal to that of ocean water and water exiting the aquifer has a salinity equal to that in the adjacent aquifer. Because Kaloko fishpond has a direct connection to the ocean, the nodes at the bottom of Kaloko fishpond also were specified-pressure nodes.

\section{Recharge and Withdrawal}

Recharge enters the model along the top, onshore boundary and along the inland east vertical boundary between altitudes of -33 and $-900 \mathrm{ft}$. Modeled recharge along the top onshore boundary (except at the nodes at and inland from the vertical confining unit) directly enters the coastal freshwaterlens system. Modeled recharge along the top onshore boundary inland from the vertical confining unit and along the inland vertical boundary directly enters the truncated inland high water-level area, which is connected to the coastal confinedgroundwater system.

Baseline recharge for the Kona area that is representative of average rainfall conditions during 1984-2008 (Engott, 2011) was used in the model (fig. 8). Recharge assigned to each onshore node at the top of the model domain was based on the area-weighted average recharge from the irregularly shaped water-budget-model subareas within a Thiessen polygon surrounding the node. Recharge used in the model at the top boundary was $30.55 \mathrm{Mgal} / \mathrm{d}$. Recharge contribution from the area upgradient of the model domain within the Keauhou aquifer system was $17.86 \mathrm{Mgal} / \mathrm{d}(7.75 \mathrm{Mgal} / \mathrm{d}$ from the northern part of the boundary and $10.11 \mathrm{Mgal} / \mathrm{d}$ from the southern part; fig. 18) and was distributed along the inland vertical boundary of the mesh between altitudes of -33 and $-900 \mathrm{ft}$. Recharge used in the groundwater model may differ slightly from that estimated by the water budget because of discretization near the coast that causes some onshore areas to be assigned to offshore nodes (or some offshore areas to be assigned to onshore nodes). Salinity of water entering at recharge nodes was assigned a value of 0.1 percent that of ocean water for the upper onshore boundary and 0.05 percent that of ocean water for the inland vertical boundary.

The average groundwater withdrawal rates from wells represented in the model were based on available data during the period 2009-13 (table 2; Robert Chenet, Hawai' $i$ Commission on Water Resource Management, written commun., 2014). Wells in the inland high water-level area are outside the modeled domain but withdrawals from these wells were included in the model by assigning the withdrawals to nearby nodes in the model, one node seaward of the inland model boundary and in the area inland of the vertical confining unit (fig. 18).

Average injection rates of wastewater into disposal wells represented in the model were based on available data and consist of (1) about $25 \mathrm{Mgal} / \mathrm{d}$ of saltwater discharged into trenches in the Natural Energy Laboratory of Hawaii Authority (NELHA) facility near Keahole Point (Keith Olson, NELHA, written commun., 2013); (2) about $0.4 \mathrm{Mgal} / \mathrm{d}$ of reverse-osmosis concentrate (62 percent ocean-water salinity; Norris Uehara, Hawai'i Department of Health, Safe Drinking Water Branch, written commun., 2020) discharged 
Table 2. Withdrawal rates and values of top and bottom altitudes assigned to wells represented in the three-dimensional numerical groundwater model, Keauhou area, Hawai'i.

[Mgal/d, million gallons per day; $\mathrm{kg} / \mathrm{s}$, kilograms per second]

\begin{tabular}{|c|c|c|c|c|c|c|c|}
\hline \multirow[b]{2}{*}{ Well number } & \multirow[b]{2}{*}{$\begin{array}{l}\text { Land-surface } \\
\text { altitude, in feet }\end{array}$} & \multirow[b]{2}{*}{$\begin{array}{l}\text { Bottom of solid } \\
\text { casing depth, in feet }\end{array}$} & \multirow[b]{2}{*}{$\begin{array}{l}\text { Well depth, in } \\
\text { feet }\end{array}$} & \multirow[b]{2}{*}{$\begin{array}{l}\text { 'Withdrawal rate, } \\
\text { in Mgal/d }\end{array}$} & \multicolumn{3}{|c|}{ Value assigned in model } \\
\hline & & & & & $\begin{array}{l}{ }^{2} \text { Top altitude, in } \\
\text { meters }\end{array}$ & $\begin{array}{l}\text { Bottom altitude, } \\
\text { in meters }\end{array}$ & $\begin{array}{c}{ }^{1} \text { Withdrawal rate, } \\
\text { in } \mathrm{kg} / \mathrm{s}\end{array}$ \\
\hline 4057-01 & 1,762 & 1,702 & 1,787 & -1.162 & 10 & -8 & -50.83 \\
\hline 4158-02 & 1,681 & 1,585 & 1,735 & -1.538 & 10 & -17 & -67.24 \\
\hline 4158-03 & 1,671 & 1,604 & 1,751 & 0.000 & 10 & -24 & 0.00 \\
\hline 4161-04 & 59 & 56 & 66 & -0.195 & 0 & -2.1 & -8.57 \\
\hline 4161-05 & 45 & 49 & 59 & -0.201 & -1.2 & -4.3 & -8.87 \\
\hline $4161-06$ & 41 & 40 & 50 & -0.238 & 0 & -2.7 & -10.46 \\
\hline $4161-07$ & 39 & 42 & 52 & -0.119 & -1 & -4.1 & -5.23 \\
\hline 4161-08 & 31 & 35 & 44.5 & -0.229 & -1.1 & -4.1 & -10.08 \\
\hline 4161-09 & 66 & 67 & 77 & -0.018 & -0.3 & -3.3 & -0.78 \\
\hline $4258-03$ & 1,681 & 1,505 & 1,823 & -0.534 & 10 & -43 & -23.37 \\
\hline $4262-01$ & 68 & 71 & 81 & -0.006 & -0.8 & -3.9 & -0.26 \\
\hline 4262-02 & 62 & 66 & 76 & -0.222 & -1.2 & -4.3 & -9.77 \\
\hline 4358-01 & 1,800 & 1,730 & 1,850 & -0.652 & 10 & -15 & -28.52 \\
\hline 4458-01 & 1,799 & 1,800 & 1,960 & 0.000 & 0 & -49 & 0.00 \\
\hline 4458-02 & 1,800 & 1,810 & 1,880 & -0.009 & -3 & -24 & -0.40 \\
\hline 4459-01 & 1,537 & 1,537 & 1,620 & -0.124 & 0 & -25 & -5.42 \\
\hline 4459-02 & 1,534 & 1,535 & 1,625 & -0.321 & -0.5 & -28 & -14.05 \\
\hline 4461-02 & 206 & 203 & 253 & -0.078 & 0 & -14 & -3.45 \\
\hline 4559-01 & 1,579 & 1,579 & 1,655 & -0.115 & 0 & -23 & -5.05 \\
\hline UH-1776 & 195 & 459 & 509 & 0.038 & -80 & -96 & 1.68 \\
\hline UH-2594 & 36 & 132 & 152 & 0.404 & -29 & -35 & 17.78 \\
\hline
\end{tabular}

${ }^{1}$ Negative value indicates withdrawal, positive value indicates injection.

${ }^{2}$ Bold value indicates that the top altitude was truncated in the model to avoid simulated withdrawal from the unsaturated zone. The top altitude for production wells was truncated at 0 meters for wells in the coastal freshwater-lens system and 10 meters for wells in the inland high water-level area.

into an injection well (UH-2594) about 0.5 mi north of KAHO (Robert Chenet, Hawai'i Commission on Water Resource Management, written commun., 2020); and (3) about $0.04 \mathrm{Mgal} / \mathrm{d}$ of wastewater (34 percent ocean-water salinity) discharged into an injection well (UH-1776) at a power-generating facility about $3 \mathrm{mi}$ north of KAHO (Norris Uehara, Hawai'i Department of Health, Safe Drinking Water Branch, written commun., 2014). Discharge of wastewater into the disposal pit southeast of KAHO is incorporated in the top recharge boundary (Engott, 2011).

\section{Estimation of Aquifer Hydraulic Properties}

Hydraulic-conductivity, effective-porosity, and dispersivity values generally are the same as those from the two-dimensional cross-section model, with adjustment and simplification to account for inclusion of the third dimension, which affects mesh discretization and regional recharge. Consistent with the two-dimensional cross-section model, effective porosity was estimated to be 0.07 for all zones except the deep coastal confined-groundwater body, for which effective porosity was assigned a value of 0.03 .

For the three-dimensional model, the dip of the dikefree volcanic rocks of the coastal freshwater-lens system was assumed to be spatially variable (horizontally and vertically) and to decrease in a seaward direction. Onshore, the assigned dip values for the dike-free volcanic rocks of the coastal freshwater-lens system were linearly interpolated in the vertical direction between the dip of the land surface and the dip of the upper confining unit $\left(1^{\circ}\right)$. For estimating the offshore dip of the volcanic rocks of the coastal freshwater-lens system, the land surface was extrapolated offshore using the near-coast 
onshore dip (fig. 18). Offshore, the assigned dip values for the dike-free volcanic rocks of the coastal freshwater-lens system were linearly interpolated in the vertical direction between the dip of the offshore extrapolation of the land surface near the coast and the dip of the upper confining unit $\left(1^{\circ}\right)$.

For the deep coastal confined-groundwater system including the upper confining unit, the assigned dip was $1^{\circ}$. The dips of the low-permeability vertical confining unit and sedimentary deposits were assigned a value of zero, but this has no effect on model results because these units were assumed to be isotropic. Inland of the vertical confining unit, the dip was assigned a value equal to the land-surface dip.

The estimated horizontal hydraulic-conductivity values were $12,000 \mathrm{ft} / \mathrm{d}$ for the dike-free volcanic rocks, $0.002 \mathrm{ft} / \mathrm{d}$ for the upper confining unit of the deep coastal confinedgroundwater system, $0.003 \mathrm{ft} / \mathrm{d}$ for the vertical extension of the upper confining unit, and $2 \mathrm{ft} / \mathrm{d}$ for the thin (one-element thick zone) offshore and fishpond sedimentary deposits. Offshore sedimentary deposits were represented in the model above an altitude of about $-180 \mathrm{ft}$. A thin zone (about $3.3 \mathrm{ft}$ ) of sedimentary deposits also was represented below the bottoms of Kaloko and 'Aimakapā fishponds. Water in the enclosed 'Aimakapā fishpond, which is exposed groundwater, was represented in the model as a zone of high hydraulic conductivity (isotropic hydraulic-conductivity value of $50,000 \mathrm{ft} / \mathrm{d}$ and porosity of 1). The vertical anisotropy (the ratio of horizontal-to-vertical hydraulic conductivity) was 50:1 for the dike-free volcanic rocks and 1:1 (isotropic) for sedimentary deposits and confining units. The horizontal anisotropy was 1:1 (isotropic) for all rocks.

For three-dimensional solute-transport simulation, SUTRA requires specification of three longitudinal dispersivity values and three transverse dispersivity values. The longitudinal dispersivity values used in the model were $250 \mathrm{ft}, 250 \mathrm{ft}$, and $5 \mathrm{ft}$ in the directions of maximum (horizontal longitudinal) hydraulic conductivity, middle (horizontal transverse) hydraulic conductivity, and minimum (vertical) hydraulic conductivity, respectively. The transverse dispersivity values used in the model were $0.16 \mathrm{ft}$ in all three directions (maximum hydraulic conductivity, middle hydraulic conductivity, and minimum hydraulic conductivity).

\section{Simulation Results}

Simulated water levels generally are consistent with a conceptual model of increasing water levels in an inland direction with an inland regional hydraulic gradient that is less than $1 \mathrm{ft} / \mathrm{mi}$ and that steepens near the coast. The simulated water levels generally are also consistent with average water levels measured during periods when the ocean level is near mean sea level (fig. 20).

Simulated vertical salinity profiles generally are consistent with measured salinity profiles (fig. 21). The simulated salinity profile from the Kamakana well (3959-01) indicates a gradual increase in salinity with depth above an altitude of about $-1,000 \mathrm{ft}$, and a relatively sharp decrease in salinity related to the deep coastal confined-groundwater system. The simulated salinity profile from the Keopu 1 deep monitor well (3858-01), which is about 1,500 feet south of the modeled area, was represented using the nearest vertical array of model nodes.

The spatial distribution of simulated steady-state salinity values is reasonably representative of average measured salinity values since 2009 within KAHO, although the simulated salinity values are generally higher than average measured values since 2009 in areas outside KAHO (fig. 22). The bias could be related to differences between actual and the modeled representation of hydrogeologic conditions, differences between the actual altitudes of water samples relative to the altitudes represented in the model, or the steadystate assumption. In the model, the altitudes of anchialine pools were assumed to be zero, and the altitudes of wells were assumed to be near the middle of the open or screened interval of the well. Because hydrologic conditions north of KAHO have changed over the past decade, the model results from steady-state simulations may reflect long-term changes that have yet to occur. North of KAHO, the Kohanaiki development adjacent to KAHO has begun withdrawing groundwater and injecting reverse-osmosis reject water into the aquifer. The withdrawals and injection at Kohanaiki are represented in the steady-state model using average rates from about 2009 to 2013. Farther north, at the Natural Energy Laboratory of Hawaii Authority, upward trends in salinity have been documented (Olson, 2018).

\section{Simulation of Selected Withdrawal and Injection Scenarios}

The three-dimensional numerical groundwater model was used to simulate hydrologic changes in KAHO for three overall scenarios: (1) withdrawal of $0.5 \mathrm{Mgal} / \mathrm{d}$, (2) withdrawal of $1.0 \mathrm{Mgal} / \mathrm{d}$, and (3) injection of $1.0 \mathrm{Mgal} / \mathrm{d}$ of high-salinity water (reverse-osmosis reject water). Withdrawals and injections were simulated in the coastal freshwater-lens system at 15 selected sites (simulated one site at a time) distributed throughout the model domain. All model simulations were run to steady-state conditions. The effect of withdrawal or injection at each site was quantified in terms of (1) average salinity change at KAHO anchialine pools that represent habitat for the endangered orangeblack Hawaiian damselfly (Megalagrion xanthomelas), and (2) average change in the pure freshwater (zero salinity) component of groundwater discharge through $\mathrm{KAHO}$, as determined from the discharge at specified-pressure nodes within KAHO. Changes in salinity and discharge were determined relative to the simulated steady-state conditions described in the previous section (Three-Dimensional Regional Model) that includes (1) baseline recharge for the Kona area that is representative of average rainfall conditions during 1984-2008, (2) average groundwater withdrawal rates during the period 2009-13, and (3) average injection rates based on available data. 


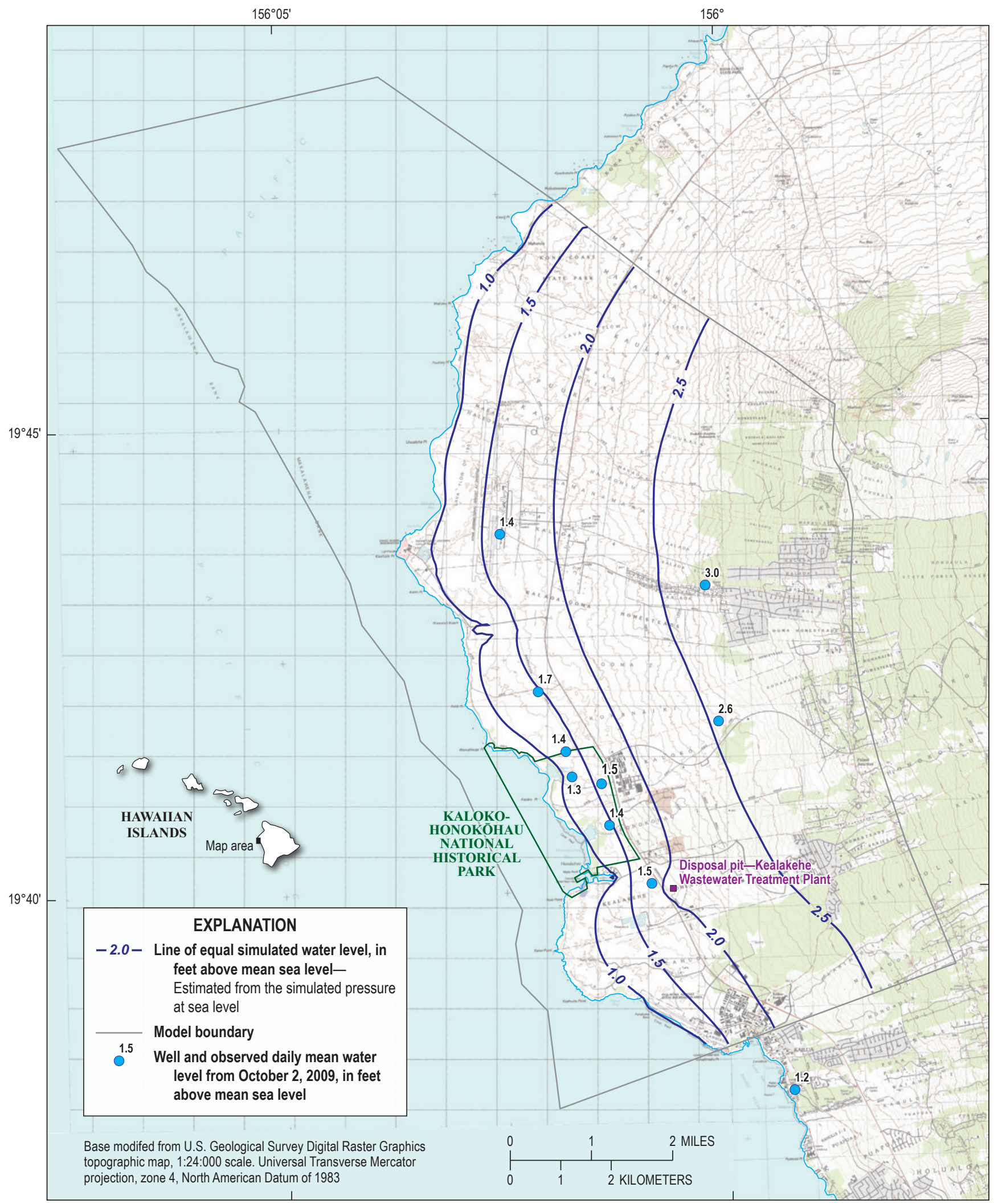

Figure 20. Map showing observed and simulated (using the three-dimensional model) water levels in the Keauhou area, Hawai'i. Observed groundwater-level data from U.S. Geological Survey (2020). 

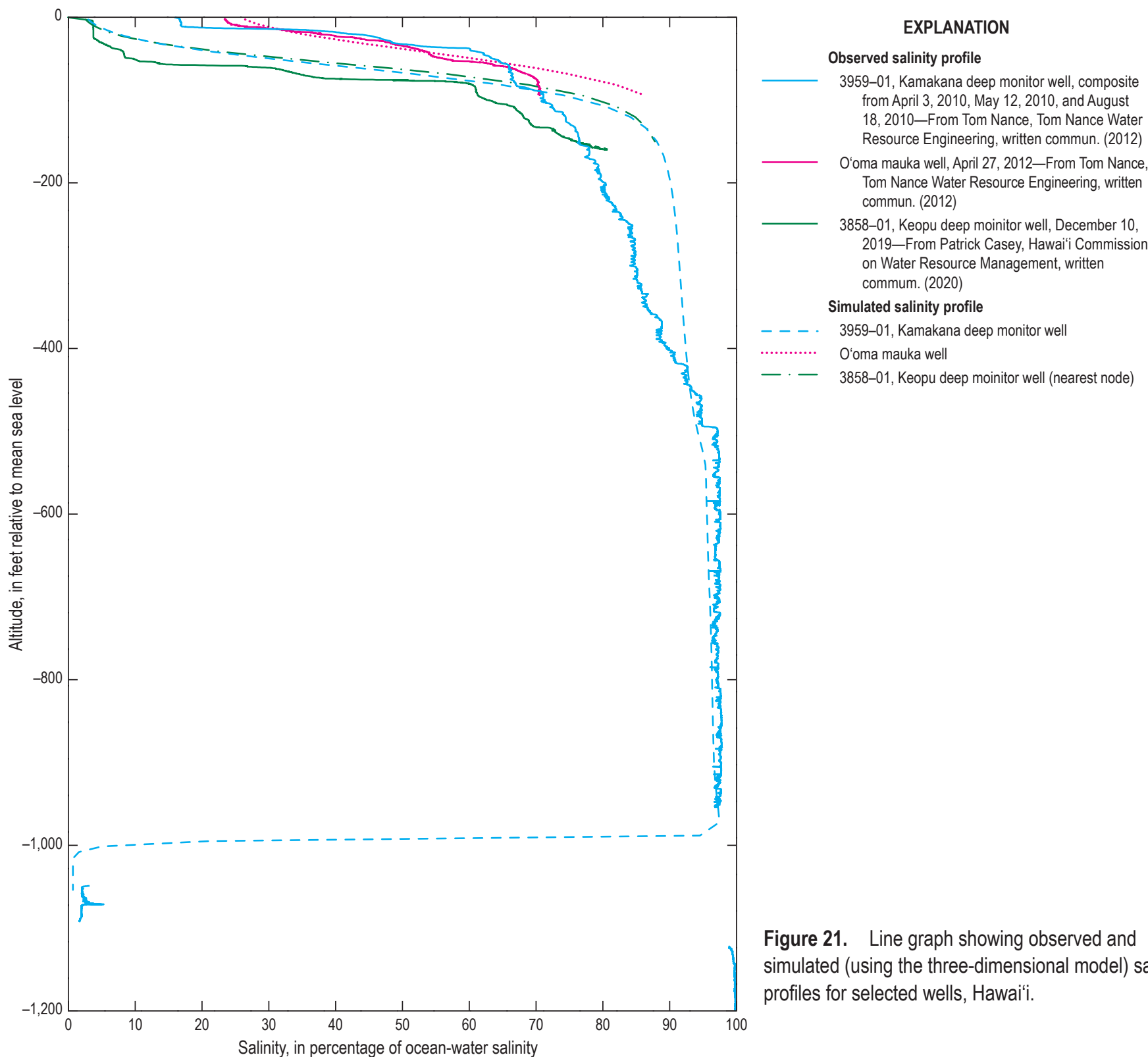

Figure 21. Line graph showing observed and simulated (using the three-dimensional model) salinity profiles for selected wells, Hawaiti.

These conditions were maintained in each simulation for the withdrawal and injection scenarios, with the addition of withdrawal or injection at one of the selected 15 sites. The results from each of the 15 selected sites were spatially contoured to provide a generalization of the hydrologic effects of withdrawal and injection. For the contouring, data were interpolated using a biharmonic-spline interpolation method (Sandwell, 1987) as implemented in GNU Octave (https:// www.gnu.org/software/octave/). The presentation of results using contours is limited because results likely are affected by the proximity of simulated withdrawals and injections to boundary conditions, which the contouring may not properly represent. This limitation can be addressed by simulating more than 15 sites of withdrawal or salinity. Although contour lines, which indicate locations of withdrawals or injections, are shown within KAHO for completeness, the likelihood of withdrawals or injections being sited within KAHO is extremely small.

\section{Scenario 1-Withdrawal of $0.5 \mathrm{Mgal} / \mathrm{d}$}

Withdrawal of $0.5 \mathrm{Mgal} / \mathrm{d}$ was simulated independently at each of 15 selected sites that are spatially distributed throughout the model domain within the area that represents the coastal freshwater-lens system (fig. 23). Thus, results for this scenario are based on 15 separate model runs. Withdrawal 


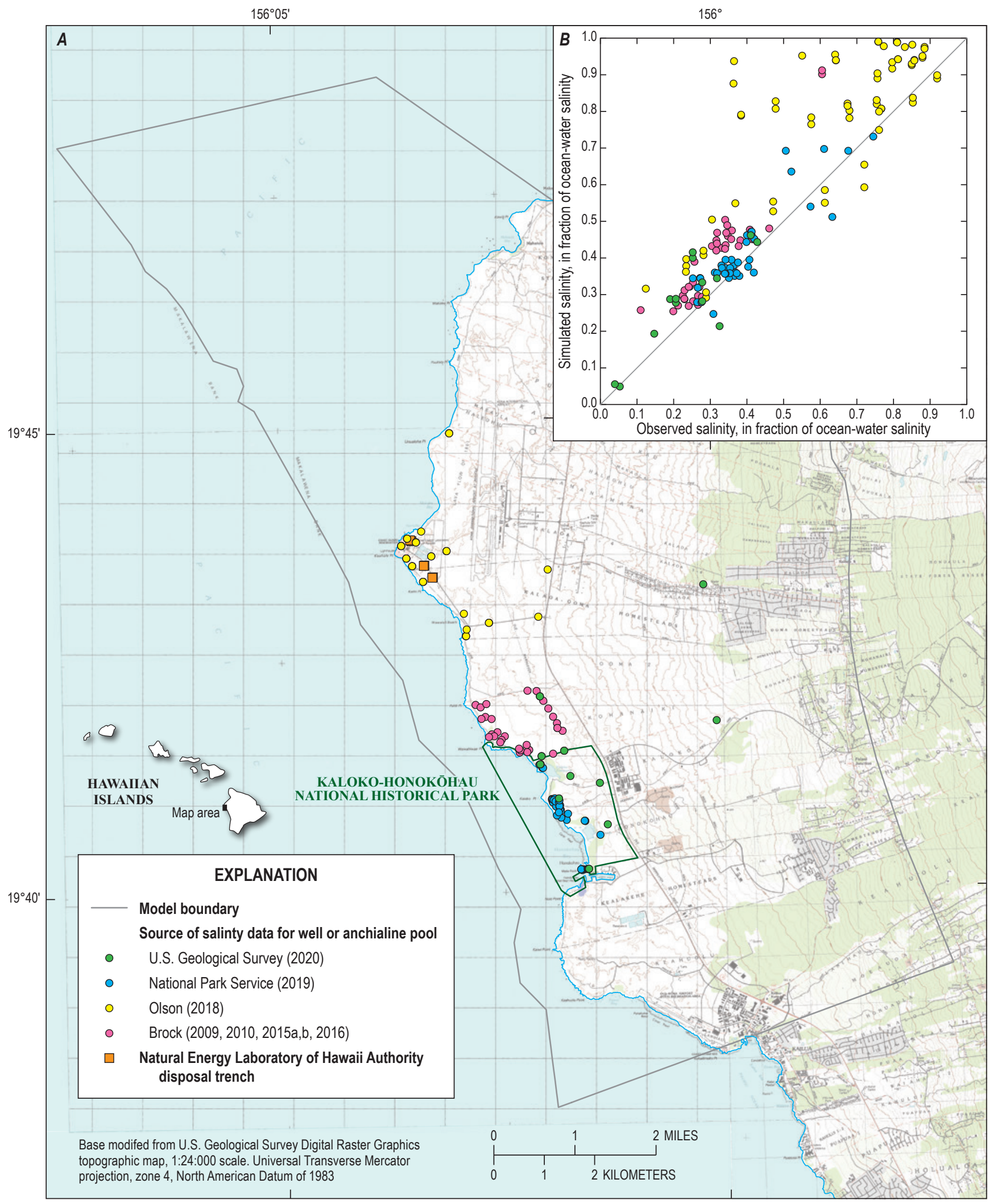

Figure 22. A, Map of the Keauhou area, Hawaili, showing the location of sites where salinity samples were collected, and $B$, scatterplot showing observed and simulated salinity values. 


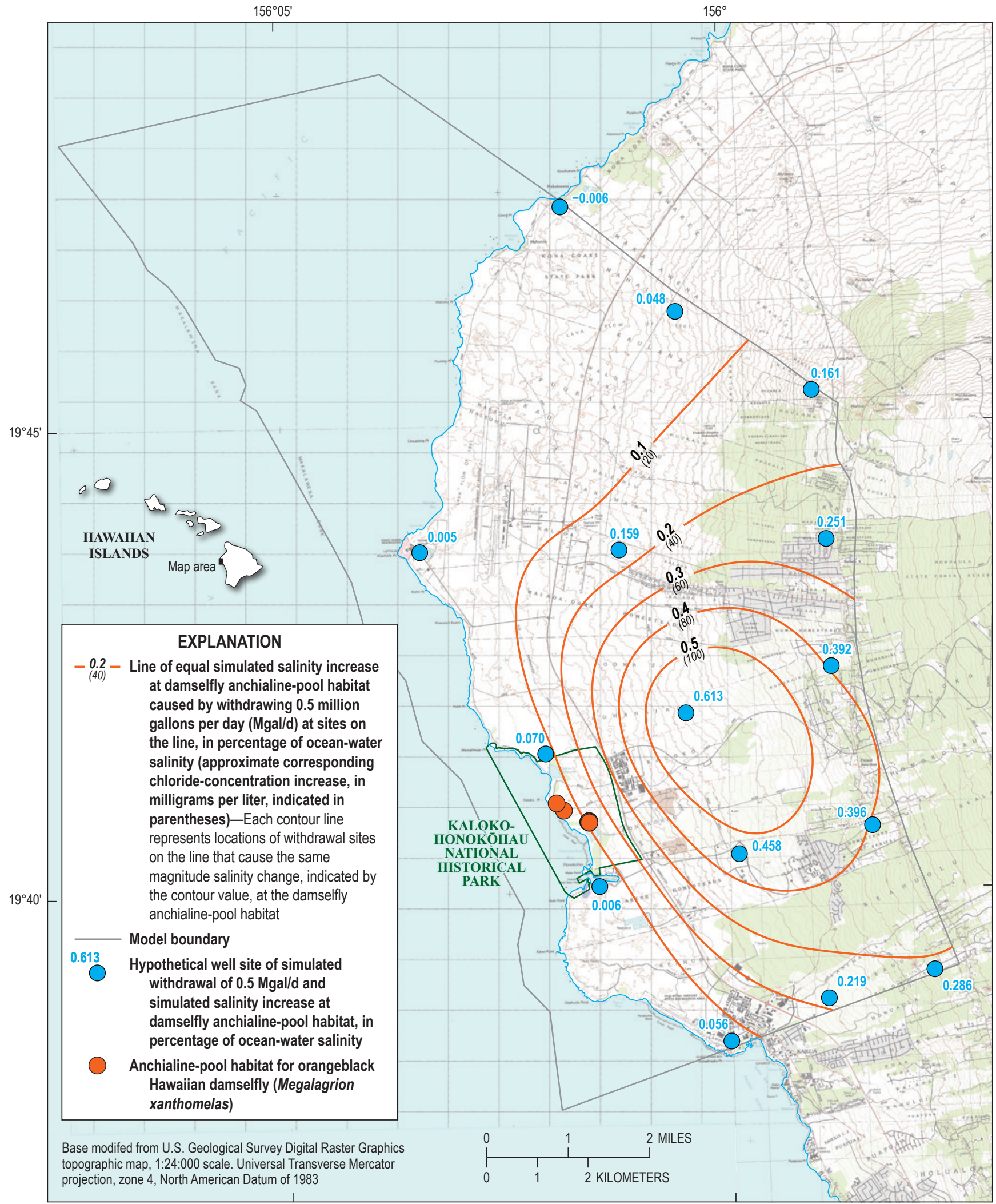

Figure 23. Map showing simulated increase in salinity, caused by the withdrawal of an additional 0.5 million gallons per day from the coastal freshwater-lens system, at the anchialine-pool habitat for the orangeblack Hawaiian damselfly (Megalagrion xanthomelas) in Kaloko-Honokōhau National Historical Park, Hawai'i. 
at each site was simulated from nodes between altitudes of -3.28 and $-9.84 \mathrm{ft}$, which represents the upper, typically freshest part of the coastal freshwater-lens system (excluding the uppermost part of the freshwater-lens system just below the water table). The results of withdrawing $0.5 \mathrm{Mgal} / \mathrm{d}$ from a site are quantified in terms of (1) the change in salinity at anchialine pools that represent habitat for the orangeblack Hawaiian damselfly, and (2) the change in the freshwater component of groundwater discharge through KAHO. Changes in salinity and discharge were determined relative to the simulated steady-state conditions described in the previous section Three-Dimensional Regional Model.

\section{Change in Salinity of Damselfly Anchialine-Pool Habitat in KAHO}

The withdrawal of $0.5 \mathrm{Mgal} / \mathrm{d}$ can affect the salinity of damselfly anchialine-pool habitat in KAHO, with the magnitude of the effect expected to vary depending on the location of the withdrawal. The change in salinity at three anchialine pools or pool groups in KAHO (fig. 23) caused by withdrawing $0.5 \mathrm{Mgal} / \mathrm{d}$ from each of 15 sites was simulated using the three-dimensional model. The simulated increase in salinity was greatest for wells located immediately inland of KAHO and least for the wells located near the coast and north of KAHO. The largest salinity increase caused by withdrawal of $0.5 \mathrm{Mgal} / \mathrm{d}$ from the selected sites was about 0.6 percent of ocean-water salinity, which corresponds to a chlorideconcentration increase of about $120 \mathrm{mg} / \mathrm{L}$, assuming ocean water has a chloride concentration of about $20,000 \mathrm{mg} / \mathrm{L}$.

The lines of equal salinity increase (fig. 23) were generated using biharmonic-spline interpolation between the 15 sites from the results of the 15 simulations. The lines of equal salinity increase indicate a pattern of greatest increase associated with wells withdrawing $0.5 \mathrm{Mgal} / \mathrm{d}$ located in an area inland of KAHO that does not extend to the boundary between the coastal freshwater-lens system and inland high water-level area, and the least increase is associated with wells near the coast. From a hydraulic standpoint, wells that withdraw groundwater near the coast are expected to have a small area of influence because the withdrawal can be balanced by a nearby reduction in coastal discharge, which is consistent with the salinity-change results. That is, withdrawal from wells near the coast will cause a limited spread of the water-level cone of depression, which is consistent with a limited spread of salinity change.

\section{Change of Freshwater Discharge Through KAHO}

Withdrawal of $0.5 \mathrm{Mgal} / \mathrm{d}$ also can affect the discharge of groundwater through KAHO, with the magnitude of the effect expected to vary depending on the location of the withdrawal. The change in groundwater discharge, in terms of the pure freshwater component of the discharge, through KAHO caused by withdrawing $0.5 \mathrm{Mgal} / \mathrm{d}$ from each of 15 sites was simulated using the three-dimensional model. The simulated reduction in freshwater discharge was greatest for wells located immediately north of KAHO and least for wells located near the coast to the north and south of KAHO. Of the 15 sites, the largest simulated freshwater-discharge reduction was about $0.18 \mathrm{Mgal} / \mathrm{d}$, which corresponds to about 2.7 percent of the simulated $6.76 \mathrm{Mgal} / \mathrm{d}$ freshwater discharge through KAHO simulated in the absence of the additional $0.5 \mathrm{Mgal} / \mathrm{d}$ withdrawal (fig. 24).

The lines of equal freshwater-discharge reduction through KAHO (fig. 24) were generated using biharmonic-spline interpolation between the 15 sites from the results of the 15 simulations. The lines of equal freshwater-discharge reduction for a withdrawal scenario of $0.5 \mathrm{Mgal} / \mathrm{d}$ indicate a pattern of greatest reduction associated with wells located in an area near the north boundary of KAHO and the least reduction associated with wells located near the coast farthest to the north and south of KAHO. The pattern of freshwater-discharge reduction (fig. 24) differs from the pattern of salinity change (fig. 23) because of differences between where the changes are being quantified. In the case of freshwater discharge, the change is determined from the specified-pressure nodes mainly within the offshore part of KAHO and also in Kaloko fishpond (fig. 18), whereas in the case of salinity, the change is determined at onshore anchialine-pool habitat for the orangeblack Hawaiian damselfly.

\section{Scenario 2-Withdrawal of $1.0 \mathrm{Mgal} / \mathrm{d}$}

Scenario 2 is similar to scenario 1 but with withdrawal at each of the 15 sites increased from 0.5 to $1.0 \mathrm{Mgal} / \mathrm{d}$. In scenario 2, withdrawal of $1.0 \mathrm{Mgal} / \mathrm{d}$ was simulated independently at each of 15 selected sites in the coastal freshwaterlens system within the model domain (fig. 25). Withdrawal at each site was again simulated from nodes between altitudes of -3.28 and $-9.84 \mathrm{ft}$. The results of withdrawing $1.0 \mathrm{Mgal} / \mathrm{d}$ from a site are quantified in terms of (1) the change (relative to the simulated steady-state conditions described in the section Three-Dimensional Regional Model) in salinity at anchialine pools that represent habitat for the orangeblack Hawaiian damselfly, and (2) the change in the pure freshwater component of groundwater discharge through KAHO.

\section{Change in Salinity of Damselfly Anchialine-Pool Habitat in KAHO}

The withdrawal of $1.0 \mathrm{Mgal} / \mathrm{d}$ can affect the salinity of damselfly anchialine-pool habitat in KAHO, with the magnitude of the effect expected to vary depending on the location of the withdrawal. The change in salinity at three anchialine pools or pool groups in KAHO (fig. 25) caused by withdrawing $1.0 \mathrm{Mgal} / \mathrm{d}$ from each of 15 sites was simulated using the three-dimensional model. The simulated increase in salinity was greatest for wells located immediately inland of KAHO and least for wells located near the coast and north of KAHO. Of the 15 sites, the largest salinity increase was about 1.1 percent of ocean-water salinity, which corresponds 


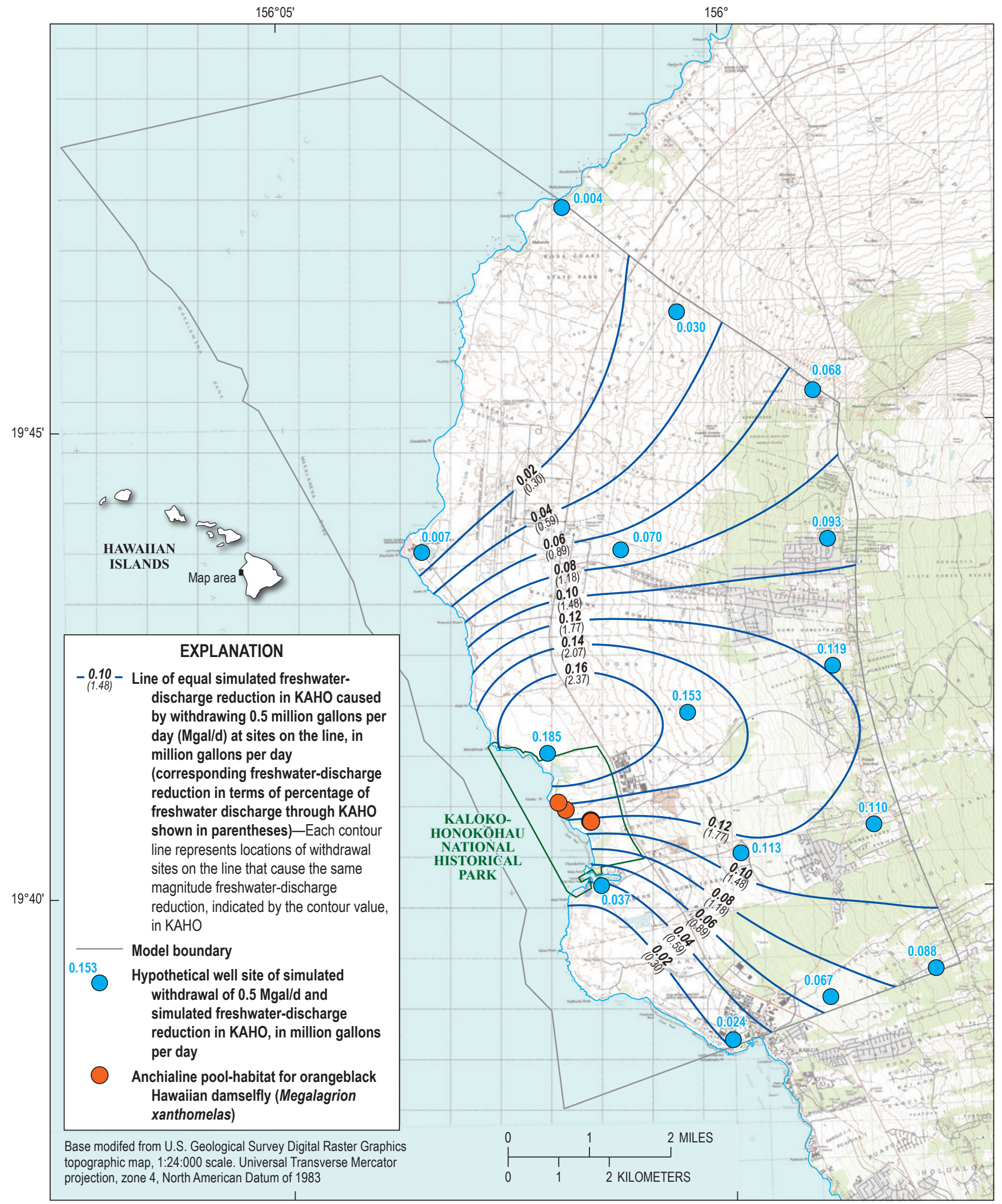

Figure 24. Map showing simulated reduction in the freshwater component of groundwater discharge through Kaloko-Honokōhau National Historical Park (KAHO) caused by the withdrawal of an additional 0.5 million gallons per day from the coastal freshwater-lens system, Hawai'i. 


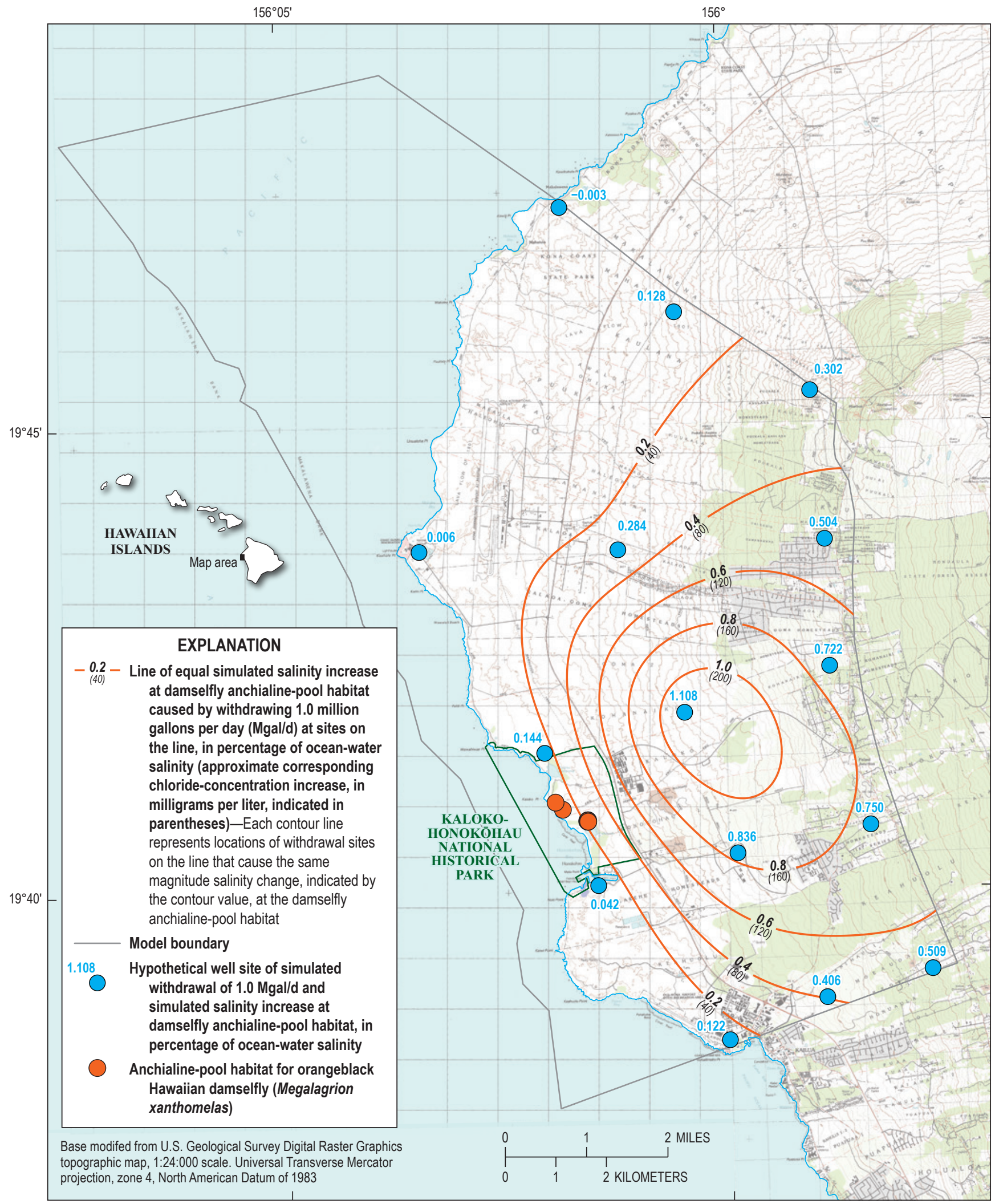

Figure 25. Map showing simulated increase in salinity, caused by the withdrawal of an additional 1.0 million gallons per day from the coastal freshwater-lens system, at anchialine-pool habitat for the orangeblack Hawaiian damselfly (Megalagrion xanthomelas) in KalokoHonokōhau National Historical Park, Hawai'i. 
to a chloride-concentration increase of about $220 \mathrm{mg} / \mathrm{L}$, assuming ocean water has a chloride concentration of about 20,000 mg/L (fig. 25).

The lines of equal salinity increase (fig. 25) were generated using biharmonic-spline interpolation between the 15 sites from the results of the 15 simulations. The lines of equal salinity increase indicate a pattern of greatest increase associated with wells withdrawing $1.0 \mathrm{Mgal} / \mathrm{d}$ located in an area inland of KAHO that does not extend to the boundary between the coastal freshwater-lens system and inland high water-level area, and the least increase associated with wells near the coast. The spatial pattern of salinity increase in scenario 2 is generally consistent with the pattern in scenario 1 , although the magnitude of the simulated increase is greater in scenario 2 relative to scenario 1 . Simulated withdrawal in scenario 2 is twice the withdrawal in scenario 1 , and the simulated salinity increase associated with withdrawal in scenario 2 is about twice the increase in scenario 1, although the response is not perfectly linear within the range of withdrawals tested (figs. 23 and 25).

\section{Change of Freshwater Discharge Through KAHO}

The change in groundwater discharge, in terms of the pure freshwater component of the discharge, through KAHO caused by withdrawing $1.0 \mathrm{Mgal} / \mathrm{d}$ from each of 15 sites was simulated using the three-dimensional model. The simulated reduction in freshwater discharge was greatest for wells located immediately north or inland of KAHO and least for wells located near the coast to the north and south of KAHO (fig. 26). Of the 15 sites, the largest simulated freshwater-discharge reduction was about $0.33 \mathrm{Mgal} / \mathrm{d}$, which corresponds to about 4.9 percent of the simulated $6.76 \mathrm{Mgal} / \mathrm{d}$ freshwater discharge through KAHO simulated in the absence of the additional $1.0 \mathrm{Mgal} / \mathrm{d}$ withdrawal (fig. 26).

The lines of equal freshwater-discharge reduction through KAHO (fig. 26) were generated using biharmonic-spline interpolation between the 15 sites from the results of the 15 simulations. The lines of equal freshwater-discharge reduction for a withdrawal scenario of $1.0 \mathrm{Mgal} / \mathrm{d}$ indicate a pattern of greatest reduction associated with wells located in an area near the north boundary of KAHO, and the least reduction associated with wells located near the coast farthest to the north and south of KAHO. The spatial pattern of freshwaterdischarge reduction in scenario 2 is generally consistent with the pattern in scenario 1, although the magnitude of the simulated reduction is greater in scenario 2 relative to scenario 1. Simulated withdrawal in scenario 2 is twice the withdrawal in scenario 1 , and the simulated freshwater-discharge reduction associated with withdrawal in scenario 2 is about twice the reduction in scenario 1 , although the response is not perfectly linear within the range of withdrawals tested (figs. 24 and 26).

\section{Scenario 3-Injection of $1.0 \mathrm{Mgal} / \mathrm{d}$}

Injection of $1.0 \mathrm{Mgal} / \mathrm{d}$ was simulated independently at each of 15 selected sites in the coastal freshwater-lens system within the model domain (fig. 27). Thus, results for this scenario are based on 15 separate model runs. Injection at each site was simulated from a vertical array of nodes; the upper and lower nodes of the vertical array of nodes were assigned to the nodes closest to altitudes of -310 and $-350 \mathrm{ft}$, respectively. The depth of injection was within the part of the aquifer with salinity greater than 50 percent of ocean-water salinity. In the simulations for scenario 3 , the salinity of the injected fluid at each of the 15 sites was set at $0.05 \mathrm{~kg} / \mathrm{kg}$, which is about 140 percent of the salinity of ocean water. The results of injecting $1.0 \mathrm{Mgal} / \mathrm{d}$ from a site are quantified in terms of (1) the change (relative to the simulated steady-state conditions described in the section Three-Dimensional Regional Model) in salinity at anchialine pools that represent habitat for the orangeblack Hawaiian damselfly, and (2) the change in the pure freshwater component of groundwater discharge through KAHO.

\section{Change in Salinity of Damselfly Anchialine-Pool Habitat in KAHO}

The injection of $1.0 \mathrm{Mgal} / \mathrm{d}$ can affect the salinity of damselfly anchialine-pool habitat in KAHO, with the magnitude and sign of the effect expected to vary depending on the location of the injection. The change in salinity at three anchialine pools or pool groups in KAHO (fig. 27) caused by injecting $1.0 \mathrm{Mgal} / \mathrm{d}$ from each of 15 sites was simulated using the three-dimensional model. The magnitude of the simulated change in salinity was greatest for wells located directly inland of KAHO and least for a well located near Keahole Point north of KAHO. Of the 15 sites, the largest salinity change was a salinity decrease of about 0.8 percent of oceanwater salinity, which corresponds to a chloride-concentration decrease of about $160 \mathrm{mg} / \mathrm{L}$, assuming ocean water has a chloride concentration of about $20,000 \mathrm{mg} / \mathrm{L}$.

The lines of equal salinity change (fig. 27) were generated using biharmonic-spline interpolation between the 15 sites from the results of the 15 simulations. The lines of equal salinity change indicate a pattern of either increased or decreased salinity at the damselfly habitat in KAHO, depending on the site of injection. Injection inland of KAHO and at sites immediately north and south of KAHO causes a simulated decrease in salinity (freshening of groundwater) at the damselfly habitat, whereas injection farther north and south of KAHO causes an increase in salinity. The greatest salinity decrease is associated with wells that inject 1.0 $\mathrm{Mgal} / \mathrm{d}$ located in an area inland of KAHO near the boundary between the coastal freshwater-lens system and inland high water-level area. The magnitude of the simulated freshening 


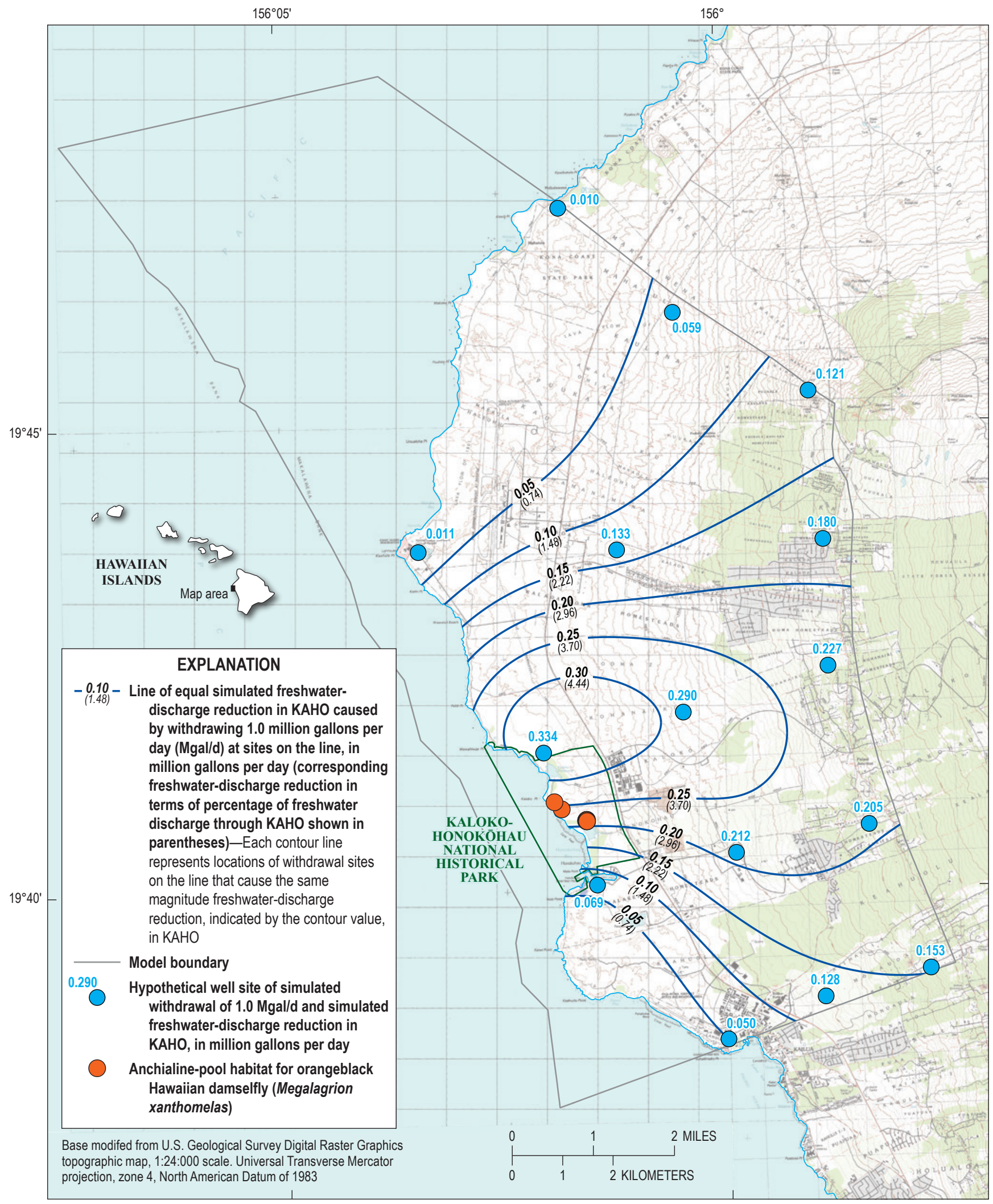

Figure 26. Map showing simulated reduction in the freshwater component of groundwater discharge through Kaloko-Honokōhau National Historical Park (KAHO) caused by the withdrawal of an additional 1.0 million gallons per day from the coastal freshwater-lens system, Hawai'i. 


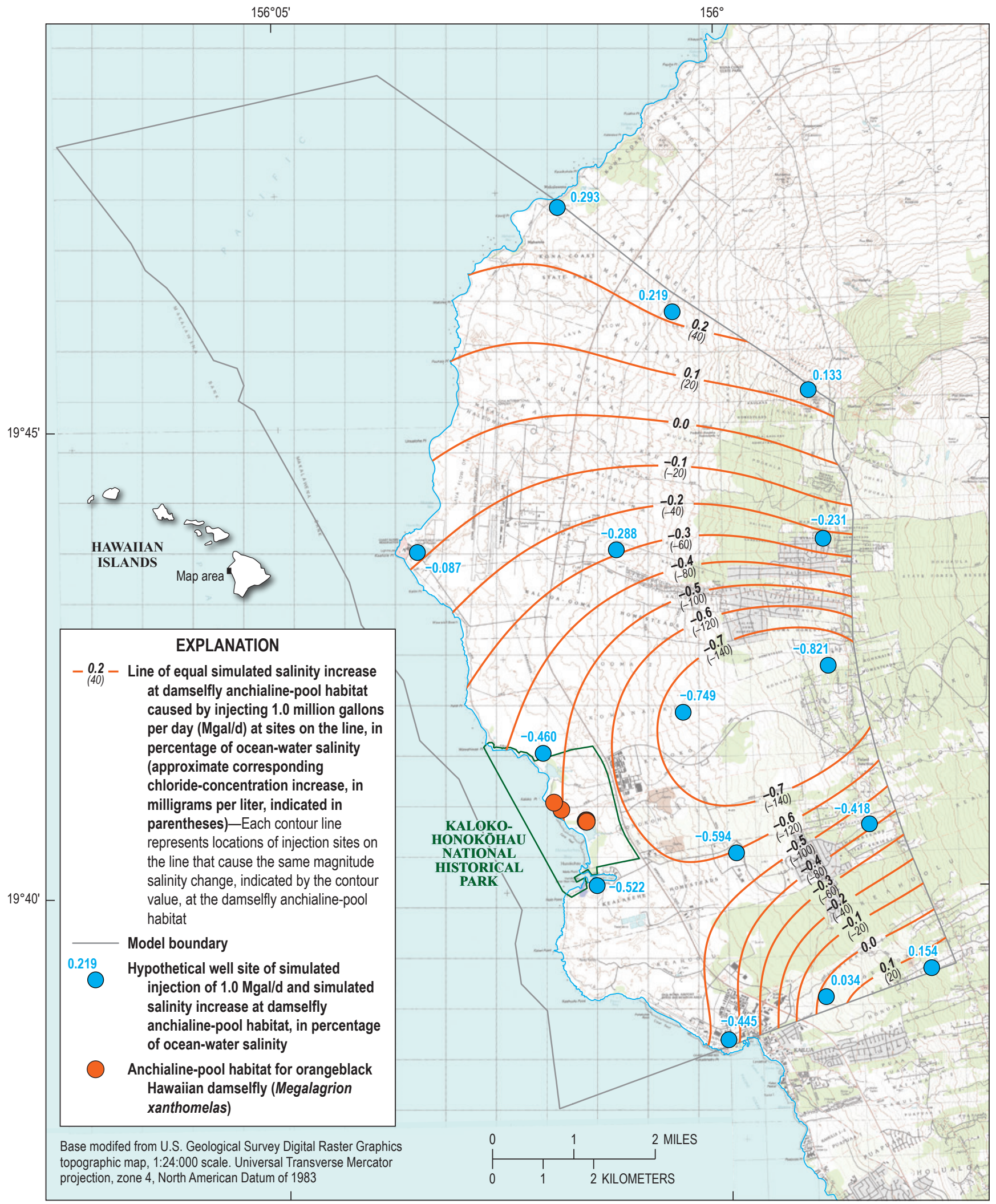

Figure 27. Map showing simulated change in salinity, caused by the injection of an additional 1.0 million gallons per day of highsalinity water into the coastal freshwater-lens system, at anchialine-pool habitat for the orangeblack Hawaiian damselfly (Megalagrion xanthomelas) in Kaloko-Honokōhau National Historical Park, Hawai'i. 
of groundwater at the damselfly habitat in KAHO associated with injecting $1.0 \mathrm{Mgal} / \mathrm{d}$ of high-salinity wastewater (denser than saltwater) generally is greatest for injection sites located in an area centered inland of KAHO and least for injection sites distant from this area. Injection at sites closer to KAHO generally causes more of a freshening of groundwater in $\mathrm{KAHO}$ than injection at sites farther from KAHO, which is hydrologically expected. However, the sense of the change varies depending on the location of the injection, with injection sites located near KAHO causing a salinity decrease at the damselfly habitat and injection sites located far from KAHO causing a salinity increase.

The simulated spatial pattern of salinity change at the damselfly habitat in KAHO is controlled by factors including the changes in fluid pressure, saltwater circulation and mixing in the coastal freshwater-lens system, and the spatial distribution of freshwater discharge from the part of the inland high water-level area represented in the model. Injection of water that is denser than ocean water causes a spatially variable change in fluid pressure in the aquifer, with greater changes both vertically and horizontally near the injection site and lesser changes distant from the injection site. Because the injected water is denser than saltwater derived from the ocean, the injected water will tend to sink within the saltwater zone. Simulated pressure changes indicate increased pressure below the injection site in the aquifer, and decreased pressure immediately around and above the injection site. Above the injection site, the simulated pressure reduction extends upward to the water table, and this pressure reduction at the water table also occurs in a zone around the injection site. In the model, these pressure changes affect saltwater circulation and mixing in the coastal freshwater-lens system and the spatial distribution of freshwater discharge from the inland high water-level area, which affects the salinity of groundwater in the freshwater-lens system. Model results indicate that injection increases groundwater salinity immediately around and below the injection site and freshens groundwater near the water table above the injection site. Near the water table, the simulated zone of freshened groundwater extends around the injection site, although a zone of increased salinity occurs distant from and outside the zone of freshened groundwater around the injection site.

For injection sites located near KAHO, model results indicate that the injection at depth restricts mixing in and near $\mathrm{KAHO}$ and increases freshwater discharge from the inland high water-level area immediately inland from the injection site (relative to the simulated steady-state conditions described in the section Three-Dimensional Regional Model), resulting in reduced salinity at the anchialine pools that represent damselfly habitat. For injection sites distant from KAHO, model results indicate that the injection at depth causes less of a salinity decrease, or even a salinity increase, at the damselfly habitat. Injection of water with a different density than that tested and at a different depth than tested may produce different results.

\section{Change of Freshwater Discharge Through KAHO}

The injection of $1.0 \mathrm{Mgal} / \mathrm{d}$ of high-salinity water also can affect the discharge of groundwater through KAHO, with the magnitude of the effect expected to vary depending on the location of the injection. The change in groundwater discharge, in terms of the freshwater component of the discharge, through KAHO caused by injecting $1.0 \mathrm{Mgal} / \mathrm{d}$ from each of 15 sites was simulated using the three-dimensional model. The simulated reduction in freshwater discharge generally was least for wells located closest to KAHO and greatest for wells located farther away from, and to the north and south of, KAHO. Of the 15 sites, the largest simulated freshwaterdischarge reduction was about $0.18 \mathrm{Mgal} / \mathrm{d}$, which corresponds to about 2.7 percent of the simulated $6.76 \mathrm{Mgal} / \mathrm{d}$ freshwater discharge through KAHO simulated in the absence of the additional $1.0 \mathrm{Mgal} / \mathrm{d}$ injection (fig. 28).

The lines of equal freshwater-discharge reduction through KAHO (fig. 28) were generated using biharmonicspline interpolation between the 15 sites from the results of the 15 simulations. The lines of equal freshwater-discharge reduction for an injection scenario of $1.0 \mathrm{Mgal} / \mathrm{d}$ indicate a pattern of least reduction associated with wells located near and immediately inland from KAHO, and greatest reduction associated with injection wells located farther north and south of KAHO. The spatial pattern of freshwater-discharge reduction in scenario 3 is different than the spatial patterns in scenarios 1 and 2, which indicate greater freshwater-discharge reduction for withdrawals located near and immediately inland from KAHO and lesser reduction for withdrawals located farther north and south of KAHO (figs. 24, 26, and 28).

The injection of high-salinity water at depth in the aquifer near KAHO causes pressure changes in the aquifer that affect saltwater circulation and mixing in the coastal freshwater-lens system, the spatial distribution of freshwater discharge from the part of the inland high water-level area represented in the model, and the pattern of groundwater flow in the freshwaterlens system. Model results indicate that injection of highsalinity water causes the salinity of groundwater to decrease in the shallower parts of the coastal freshwater-lens system near the water table in a zone around the injection site and increase in the deeper parts of the system. Thus, particularly for injection sites near KAHO, the injection causes the salinity of groundwater near the water table to decrease onshore and in the nearshore area within KAHO, as reflected in the decreased salinity in damselfly anchialine-pool habitat in KAHO (fig. 27). In the deeper parts of the aquifer within KAHO (tens of feet below the anchialine pools), however, the salinity of groundwater increases, which results in an overall reduction in the freshwater component of groundwater discharge in KAHO caused by the injection of high-salinity water at depth.

For all simulated injection sites, the injection causes a reduction in freshwater discharge in KAHO, which includes deep offshore areas where salinity increases in the aquifer. 


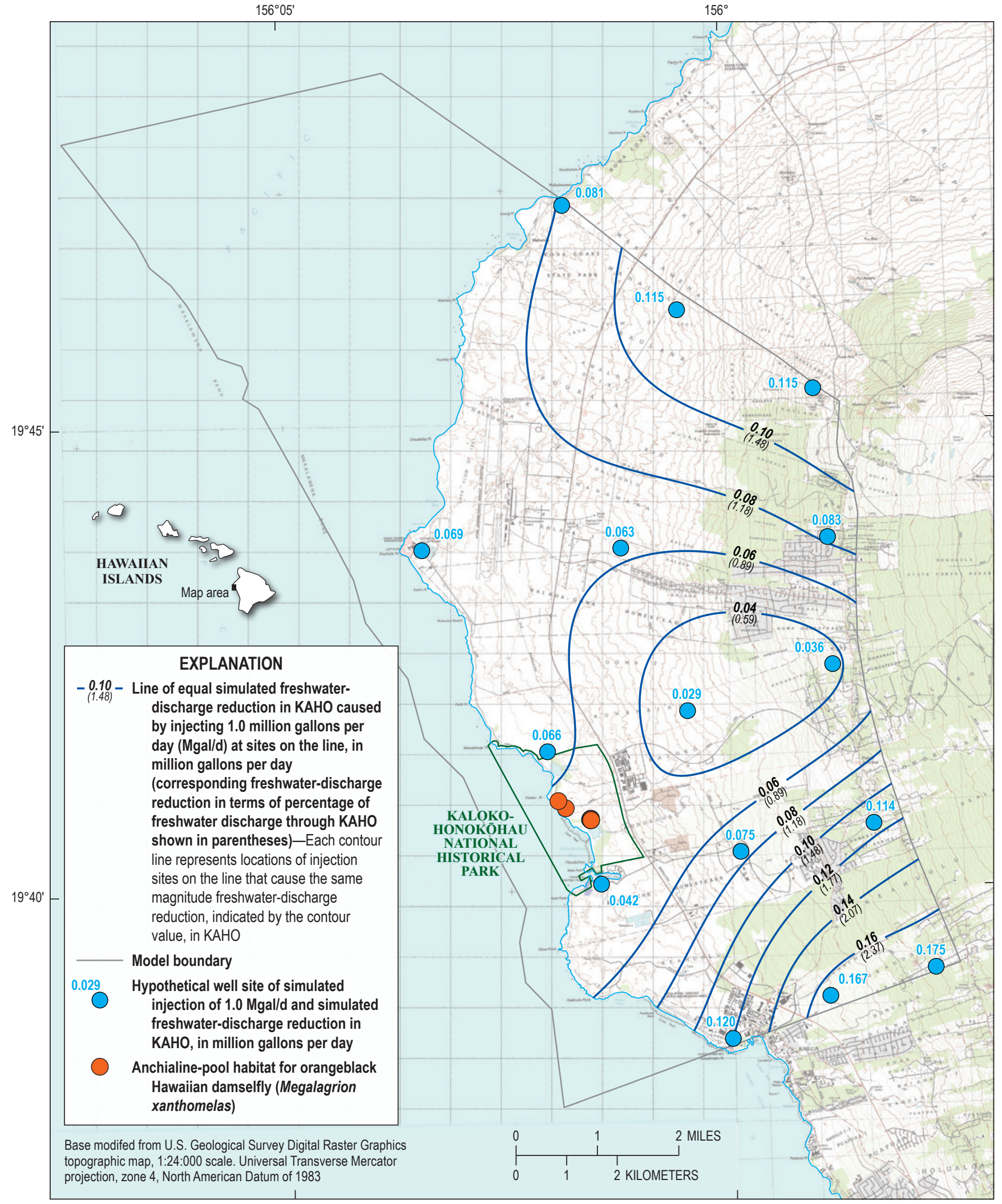

Figure 28. Map showing simulated reduction in the freshwater component of groundwater discharge through Kaloko-Honokōhau National Historical Park (KAHO) caused by the injection of an additional 1.0 million gallons per day of high-salinity water into the coastal freshwater-lens system, Hawai'i. 
In general, the magnitude of the freshwater-discharge reduction increases with the distance of the injection site from $\mathrm{KAHO}$, which reflects the patterns of salinity change and groundwater-discharge change in the aquifer. For injection sites near KAHO, the injection causes greater freshening of shallow groundwater in $\mathrm{KAHO}$, in both magnitude and spatial extent, relative to injection sites distant from KAHO, and this largely controls the pattern of freshwater-discharge reduction in KAHO (fig. 28).

\section{Implications of Scenarios}

Results of the simulated withdrawal and injection scenarios indicate that increased withdrawals or injection, relative to recent rates, may affect the quality and quantity of groundwater in KAHO. All other factors being equal, high rates of withdrawal will tend to have a greater effect on groundwater conditions in KAHO relative to low rates of withdrawal. All other factors being equal, withdrawal at sites close to KAHO will tend to have a greater effect on groundwater conditions in KAHO relative to withdrawal at sites distant from KAHO. The simulated injection of high salinity water at depth in the aquifer causes a reduction of freshwater discharge through KAHO and may cause a decrease in salinity at selected sites in KAHO. Changes in groundwater quality and quantity in KAHO may have either negative or positive ecologic effects, depending on the magnitude and direction of the changes and the tolerance of different species and life stages of those species to the changes. Evaluation of the ecologic effects of the simulated changes in groundwater quality and quantity in KAHO is needed but is beyond the scope of this study. Because of uncertainties in hydrogeologic conditions in the Keauhou aquifer system, model results also contain unquantified uncertainty and the accuracy of results may be limited.

\section{Limitations}

The lack of data and understanding of the subsurface geology constrains the ability to accurately model the groundwater-flow system. Different conceptual models of the groundwater-flow system in the Keauhou and adjacent aquifer systems currently exist. The two-dimensional cross section models were used to test different conceptual models of the groundwater-flow system. However, the understanding of subsurface geological conditions can be improved and conceptual models of the groundwater-flow system can be best refined by collecting information from exploratory drilling of wells. Data from a limited number of wells currently are available to constrain the conceptual model, particularly in the deep coastal confined-groundwater system and inland high water-level area. Information from additional exploratory wells also will provide direct information to develop and constrain supplemental studies using geophysical methods. An evaluation of the hydrologic effects of groundwater withdrawals from the inland high water-level area and deep coastal confined-groundwater system is needed, but was excluded from this study because of a lack of understanding of the geologic structures that impound groundwater in the inland high water-level area and the hydrogeologic connection between the inland high water-level area and deep coastal confined-groundwater system.

The numerical groundwater models developed for this study have a number of limitations, including their nonuniqueness and inability to account for local-scale heterogeneities. Different distributions of hydraulic properties and recharge may result in comparable regional model results. The numerical models developed for this study also simulate conditions on a regional scale and may not accurately predict either the water level or salinity at a particular location in the aquifer. Salinity of water in an anchialine pool may be controlled by local heterogeneities in the aquifer that are not represented in the model. Also, the level of model discretization affects the numerical accuracy with which transport mechanisms are simulated. Refined discretization in and near KAHO would tend to improve model accuracy in areas of concern, although this could also result in increased time required to complete model simulations. The model has several other limitations for predictive purposes because of the various assumptions used and possible uncertainties in input data. These limitations are discussed below.

Differences between measured and simulated water levels and salinities are greater in some areas than others, which may reflect uncertainties in recharge or withdrawal, boundary conditions, assigned parameter values in the model, or representations of the different hydrogeological features in the model. For this study, recharge in the modeled area was assumed to be limited to the recharge within the Keauhou aquifer system, although recharge from adjacent aquifer systems may enter the Keauhou aquifer system and contribute to recharge in the modeled area. Additional information on the hydrologic interconnection between adjacent aquifer systems could improve model results. Recharge estimates in Hawai'i generally are based on water-budget computations that could be improved with a better understanding of the spatial distributions of rainfall, evapotranspiration, runoff, and land-cover characteristics. Other studies that could enhance the understanding of recharge include (1) quantifying rates of evapotranspiration of native and nonnative forest species, (2) directly measuring recharge using field lysimeters, (3) measuring changes in soil moisture below the plant root zone, (4) quantifying local recharge related to dry wells or wastewater disposal, and (5) quantifying increases in the chloride concentration of infiltrating water caused by evapotranspiration. Improved recharge estimates in the study area will lead to improved estimates for parameter values in the numerical groundwater model and greater confidence in model results.

For this study, no-flow boundaries were assigned in the northwest and south, which precludes the movement of groundwater across these boundaries. The northwest boundary of the model corresponds to the northwest rift zone of Hualālai volcano, which likely represents a hydrogeological barrier 
to groundwater flow. The south boundary does not coincide with any known hydrogeological barrier and was generally aligned with the regional groundwater-flow direction. Because of its proximity to KAHO, the south boundary may affect model simulations. In general, the magnitude of simulated effects may be overestimated because of the truncation of the southern part of the model domain.

Heterogeneity in the groundwater system likely exists but is currently poorly understood. The values assigned to model hydraulic parameters generally were based on existing estimates and controlled by observed hydrogeologic conditions. However, some of these parameter values may be poorly known. Simulated water levels are typically controlled by the hydraulic-conductivity values assigned in the model. Simulated salinity can be controlled by various hydraulic parameters.

Confidence in model results can be improved by addressing the limitations described in this section and other limitations that were not described. Improved estimates of recharge and the distribution of model parameter values will lead to an increase of model reliability. The model developed for this study was developed for steady-state conditions. The groundwater system likely is not currently in a steady-state condition because of changes in land cover, withdrawals, and wastewater disposal. Thus, model calibration to short-term, tidally influenced data and transient long-term data using available water-level and water-quality data, including available water-isotope and age-dating data of water samples, can be used to better constrain model boundaries and parameter values. Representation of conduit flow and flow in highpermeability clinker zones at a local scale potentially will lead to improved understanding of the effects of withdrawal and injection near KAHO (for example, Kreyns and others, 2020).

The hypothetical simulations of withdrawal and injection can be refined in the future if rates, locations, and depths of withdrawal or injection are known. Also, the effects of climate change on the groundwater system were not addressed in this study but can be simulated in the future, particularly as the effects of climate change on groundwater recharge and sea level are better understood.

\section{Summary}

Kaloko-Honokōhau National Historical Park (KAHO) is located on the west coast of the island of Hawai' $i$ within the Keauhou aquifer system, as defined by the Hawai' $i$ Commission on Water Resource Management. The waters in KAHO represent an important resource that made it possible for Native Hawaiians to settle in the arid area. The fishponds, wetlands, anchialine pools, and marine waters are cultural resources and provide habitat for threatened, endangered, and other culturally important native species. KAHO's water resources are sustained by, and in the case of the anchialine pools and 'Aimakapā fishpond are mainly dependent on, groundwater discharge for freshwater input. Hawaiian anchialine pools support rare endemic species, some of which remain undescribed, and two species listed as endangered by the U.S. Fish and Wildlife Service: the orangeblack Hawaiian damselfly (Megalagrion xanthomelas) and an anchialine pool shrimp (Procaris hawaiana).

In 1978, the year of KAHO authorization, the lands immediately surrounding KAHO were undeveloped and zoned for conservation purposes; at present, these lands mostly are either developed, or zoned for industrial, commercial, or residential use. Urbanization of the North Kona District has increased the need for additional drinking and nonpotable (irrigation) water. KAHO's water resources may be affected by existing and proposed groundwater withdrawals and injections of high-salinity water in the surrounding area. This study was undertaken to refine the understanding of how anthropogenic factors, including increased groundwater withdrawals and injection of high-salinity water (reverse-osmosis reject water), may affect KAHO's water resources.

The purpose of this report is to provide information related to how anthropogenic factors may affect water resources in Kaloko-Honokōhau National Historical Park. Specifically, this report presents estimates of changes in salinity and groundwater discharge in KAHO caused by selected scenarios of groundwater withdrawal and injection of high-salinity water into the aquifer. To meet the objectives of the study, a numerical groundwater model that accounts for the recently discovered coastal confined-groundwater system was constructed.

Previously published groundwater-recharge estimates were used to construct the numerical, density-dependent groundwater flow and transport model capable of simulating changes in salinity and discharge caused by anthropogenic factors.

Aquifer hydraulic properties for the three-dimensional numerical groundwater model were estimated using available water-level and salinity information. A steady-state baseline condition was simulated and used as a basis for determining potential change caused by additional withdrawal or injection. The baseline condition consisted of (1) baseline recharge for the Kona area that is representative of average rainfall conditions during 1984-2008, (2) average groundwater withdrawal rates during the period 2009-13, and (3) average injection rates based on available data. The three-dimensional numerical groundwater model was used to simulate steadystate hydrologic changes in KAHO for three overall scenarios: (1) withdrawal of 0.5 million gallons per day; (2) withdrawal of 1.0 million gallons per day; and (3) injection of 1.0 million gallons per day of reverse-osmosis reject water.

Model results indicate that the withdrawal of additional groundwater from the coastal freshwater-lens system will affect the salinity of anchialine pool habitat for the orangeblack Hawaiian damselfly. The magnitude of the effect is dependent on the amount and location of the withdrawal. Greater withdrawal rates cause greater increases in salinity in $\mathrm{KAHO}$, other factors being equal, although the salinity increase is not perfectly linearly related to the withdrawal rate within the range of withdrawals tested. For a given withdrawal rate, the greatest increase in salinity in KAHO is associated with wells located in an area inland of KAHO, and the least increase is associated with wells located near the coast. 
Model results also indicate that the withdrawal of additional groundwater from the coastal freshwater-lens system will affect the groundwater discharge, in terms of the freshwater component of the discharge, through KAHO. The magnitude of the freshwater-discharge reduction through $\mathrm{KAHO}$ is dependent on the amount and location of the withdrawal. Greater withdrawal rates cause greater reductions in freshwater discharge through KAHO, other factors being equal, although the discharge reduction is not perfectly linearly related to the withdrawal rate within the range of withdrawals tested. For a given withdrawal rate, the greatest reduction in freshwater discharge through KAHO is associated with wells located near the north boundary of KAHO, and least reduction is associated with wells located near the coast farther to the north and south of KAHO.

The injection of high-salinity water (140 percent of the salinity of ocean water) can affect the salinity of damselfly habitat in KAHO, with the magnitude of the effect dependent on the location of the injection. Model results indicate that salinity may either increase or decrease at the damselfly habitat in KAHO, depending on the site of injection and how the injection affects saltwater circulation and mixing, as well as the distribution of freshwater discharge from the part of the inland high water-level area represented in the model. Injection of high-salinity water inland of KAHO and at sites immediately north and south of KAHO causes a simulated decrease in salinity at the damselfly habitat, whereas injection farther north and south of KAHO causes an increase in salinity. Injection of high-salinity water also causes a reduction in freshwater discharge through $\mathrm{KAHO}$, with the greatest reduction within the area considered for this analysis associated with distant injection wells to the north and south of KAHO and the least reduction associated with wells located near and directly inland from KAHO.

Changes in groundwater quality and quantity in KAHO may have either negative or positive ecologic effects, depending on the magnitude and direction of the changes and the tolerance of different species and life stages of those species to the changes. Evaluation of the ecologic effects of the simulated changes in groundwater quality and quantity in $\mathrm{KAHO}$ is needed but is beyond the scope of this study.

The numerical groundwater models developed for this study have a number of limitations. The lack of data and understanding of the subsurface geology constrains the ability to accurately model the groundwater-flow system. The understanding of subsurface geological conditions can be improved and conceptual models of the groundwater-flow system can be best refined by collecting information from exploratory drilling of wells. The models developed for this study are nonunique; cannot account for local-scale heterogeneities in the aquifer; and contain uncertainties related to recharge, boundary conditions, assigned parameter values in the model, and representations of the different hydrogeological features. Confidence in model results can be improved by addressing these and other limitations. In spite of these limitations, the three-dimensional numerical model developed for this study provides a useful conceptual understanding of the potential effects of additional withdrawals and injections on groundwater resources in KAHO.

\section{References Cited}

Arguez, A., Applequist, S., Vose, R., Durre, I., Squires, M., and Yin, X., 2011, NOAA's 1981-2010 climate normals, methodology of temperature-related normals: National Oceanic and Atmospheric Administration, National Climatic Data Center online report, accessed July 31, 2013, at http://www1.ncdc.noaa.gov/pub/data/normals/1981-2010/ documentation/temperature-methodology.pdf.

Attias, E., Thomas, D., Sherman, D., Ismail, K., and Constable, S., 2020, Marine electrical imaging reveals novel freshwater transport mechanism in Hawai'i: Science Advances, v. 6, no. 48, accessed November 30, 2020, at https://advances. sciencemag.org/content/6/48/eabd4866.full.

Bauer, G.R., 2003, A study of the ground-water conditions in North and South Kona and South Kohala Districts island of Hawaii, 1991-2002: State of Hawai'i, Commission on Water Resource Management, PR-2003-01, 75 p. plus appendix, accessed March 25, 2020, at http://files.hawaii. gov/dlnr/cwrm/publishedreports/PR200301.pdf.

Bauer, G.R., 2011, Geologic log, Kamakana well no. 3959-01, Kealakehe, Hawaii: State of Hawai' $i$, Commission on Water Resource Management, accessed November 30, 2020, at https://www.higp.hawaii.edu/hggrc/wells/wells.php.

Bowles, S.P., 2007, A review of NPS comments Re: water development impacts for the Shores at Kohanaiki: Waimea Water Services Inc. report, June 2007, 18 p.

Bowles, S.P., 2008, Observation well recommendations, The Shores at Kohanaiki: Waimea Water Services, Inc. report, revised May 20, 2008, 9 p.

Brock, R., 2009, Water quality monitoring report for the development of The Shores at Kohanaiki, north Kona in the during construction period-10 February and 7 April 2009 dry period surveys and 13 January 2009 wet period survey: EAC report no. 2009-16, October 2009, prepared for Kohanaiki Golf and Ocean Club, Discovery Land Company, $113 \mathrm{p}$.

Brock, R., 2010, Water quality monitoring report for the development of The Shores at Kohanaiki, north Kona in the during construction period-13 July, 1 September and 10 November 2009 dry period surveys: EAC report no. 2010-06, March 2010, prepared for Kohanaiki Golf and Ocean Club, Discovery Land Company, 123 p.

Brock, R., 2015a, Water quality monitoring report for the development of The Shores at Kohanaiki, north Kona in the during construction period-8 July, 20 August and 7 October 2014 dry period surveys: EAC report no. 2015-01, January 2015, prepared for Kohanaiki Golf and Ocean Club, Discovery Land Company, 129 p. 
Brock, R., 2015b, Water quality monitoring report for the development of The Shores at Kohanaiki, north Kona in the during construction period-4 December 2014, 2 February and 29 April 2015 dry period surveys: EAC report no. 2015-15, July 2015, prepared for Kohanaiki Golf and Ocean Club, Discovery Land Company, 138 p.

Brock, R., 2016, Water quality monitoring report for the development of The Shores at Kohanaiki, north Kona in the during construction period-8 June, 18 August and 29 September dry period surveys and following a high rainfall event 26 August 2015: EAC report no. 2016-01, January 2016, prepared for Kohanaiki Golf and Ocean Club, Discovery Land Company, 143 p.

Brock, R.E., and Kam, A.K.H., 1997, Biological and water quality characteristics of anchialine resources in the Kaloko-Honokohau National Historical Park: Cooperative National Park Resources Studies Unit, University of Hawai'i Sea Grant College Program, Honolulu, Hawai' $i$, Technical report 112, 110 p., accessed April 23, 2020, at http://hdl.handle.net/10125/7396.

Büttner, G., and Huenges, E., 2003, The heat transfer in the region of the Mauna Kea (Hawaii) - Constraints from borehole temperature measurements and coupled thermohydraulic modeling: Tectonophysics, v. 371, p. 23-40, accessed April 23, 2020, at https://doi.org/10.1016/S00401951(03)00197-5.

Cannon, E.C., Bürgmann, R. Crone, A.J., Machette, M.N., and Dart, R.L., 2007, Map and data for Quaternary faults and fault systems on the Island of Hawai' $\mathrm{i}$ : U.S. Geological Open-File Report 2007-1284, 81 p., 1 plate, accessed April 23, 2020, at https://pubs.usgs.gov/of/2007/1284/.

Carignan, K.S., Taylor, L.A., Eakins, B.W., Friday, D.Z., Grothe, P.R., Lim, E., and Love, M., 2011, Digital elevation models of Keauhou and Kawaihae, HawaiiProcedures, data sources, and analysis: National Oceanic and Atmospheric Administration, National Geophysical Data Center, 29 p., accessed April 23, 2020, at https://www. ngdc.noaa.gov/mgg/dat/dems/regional_tr/keauhou_13_ mhw_2011.pdf.

Clague, D.A., 1982, Petrology of tholeiitic basalt dredged from Hualalai Volcano, Hawaii [abs.]: Eos, American Geophysical Union Transactions, v. 63, no. 45, p. 1138, accessed April 23, 2020, at https://doi.org/10.1029/ EO063i045p00889.

Clague, D.A., 1987, Hawaiian xenolith populations, magma supply rates, and development of magma chambers: Bulletin of Volcanology, v. 49, no. 4, p. 577-587, accessed April 23, 2020, at https://doi.org/10.1007/BF01079963.

Clague, D.A. and Moore, J.G., 1991, Geology and petrology of Mahukona volcano, Hawaii: Bulletin of Volcanology, v. 53, no. 3, p. 159-172, accessed April 23, 2020, at https:// doi.org/10.1007/BF00301227.
Cole, B.E., and Silliman, S.E., 1996, Estimating the horizontal gradient in heterogeneous, unconfined aquifers - Comparison of three-point schemes: Groundwater Monitoring and Remediation, v. 16, no. 2, p. 84-91, accessed November 30, 2020, at https://doi. org/10.1111/j.1745-6592.1996.tb00128.x.

Cooper, H.H., Jr., Kohout, F.A., Henry, H.R., and Glover, R.E., 1964, Sea water in coastal aquifers: U.S. Geological Survey Water-Supply Paper 1613-C, 84 p., accessed April 23, 2020, at https://pubs.usgs.gov/wsp/1613c/.

County of Hawai 'i, 2019, Mapping Kona’s future, Kona Community Development Plan, final as amended: County of Hawai'i Planning Department, v. 1, September 2008, amended September 18, 2019, accessed March 18, 2020, at https:/www.hawaiicountycdp.info/north-and-south-konacdp/kona-cdp-document.

Cousens, B.L., Clague, D.A., and Sharp, W.D., 2003, Chronology, chemistry, and origin of trachytes from Hualalai Volcano, Hawaii: Geochemistry, Geophysics, Geosystems, v. 4, no. 9, accessed April 23, 2020, at https:// doi.org/10.1029/2003GC000560.

Domenico, P.A., and Schwartz, F.W., 1990, Physical and chemical hydrogeology: New York, John Wiley, 824 p.

Elison Timm, O., Giambelluca, T.W., Diaz, H.F., Takahashi, M., and Frazier, A., 2013, Statistical downscaling of rainfall for the Hawaiian Islands using CMIP3 and CMIP5 model scenarios: University of Hawai'i at Mānoa, International Pacific Research Center, Asia-Pacific Data-Research Center, accessed January 8, 2014, at http://apdrc.soest.hawaii.edu/ projects/SD/.

Elison Timm, O., Giambelluca, T.W., and Diaz, H.F., 2015, Statistical downscaling of rainfall changes in Hawai' $i$ based on the CMIP5 global model projections: Journal of Geophysical Research-Atmospheres, v. 120, no. 1, p. 92-112, accessed December 3, 2020, at https://doi. org/10.1002/2014JD022059.

Engott, J.A., 2011, A water-budget model and assessment of groundwater recharge for the Island of Hawai' $i$ : U.S. Geological Survey Scientific Investigations Report 20115078, 53 p., accessed April 23, 2020, at https://pubs.usgs. gov/sir/2011/5078/.

Fackrell, J.K., 2016, Geochemical evolution of Hawaiian groundwater: Honolulu, Hawai'i, University of Hawai'i at Mānoa, Ph.D. dissertation, 160 p., accessed February 2, 2017, at https://scholarspace.manoa.hawaii.edu/ handle/10125/51484.

Flinders, A.F., Ito, G., Garcia, M.O., Sinton, J.M., Kauahikaua, J., and Taylor, B., 2013, Intrusive dike complexes, cumulate cores, and the extrusive growth of Hawaiian volcanoes: Geophysical Research Letters, v. 40, no. 13, p. 3367-3373, accessed April 23, 2020, at https://doi.org/10.1002/ grl.50633. 
Furumoto, A.S., Campbell, J.F., and Hussong, D.M., 1970, Seismic studies of subsurface structure in the Ewa coastal plain, Oahu, Hawaii: Pacific Science, v. 24, no. 4, p. 529-542, accessed April 23, 2020, at http://hdl.handle. net/10125/6267.

Garcia, M.O., Muenow, D.W., Aggrey, K.E., and O’Neil, J.R., 1989, Major element, volatile, and stable isotope geochemistry of Hawaiian submarine tholeiitic glasses: Journal of Geophysical Research-Solid Earth, v. 94, no. B8, p. 10525-10538, accessed April 23, 2020, at https://doi.org/10.1029/JB094iB08p10525.

Giambelluca, T., and Sanderson, M., 1993, The water balance and climatic classification, chap. 4 of Sanderson, M., ed., Prevailing trade winds: Honolulu, University of Hawai' $i$ Press, p. 56-72.

Giambelluca, T.W., Chen, Q., Frazier, A.G., Price, J.P., Chen, Y.-L., Chu, P.-S., Eischeid, J.K., and Delparte, D.M., 2013, Online rainfall atlas of Hawai' $i$ : Bulletin of the American Meteorological Society, v. 94, no. 3, p. 313-316, accessed April 23, 2020, at https://doi.org/10.1175/BAMSD-11-00228.1.

Giambelluca, T.W., Nullet, M.A., and Schroeder, T.A., 1986, Rainfall atlas of Hawai'i: State of Hawai'i, Department of Land and Natural Resources, Report R76, 267 p., accessed April 23, 2020, at http://files.hawaii.gov/dlnr/cwrm/ publishedreports/R76_Rainfall.pdf.

Gibbs, A.E., Cochran, S.A., Logan, J.B., and Grossman, E.E., 2007, Benthic habitats and offshore geological resources of Kaloko-Honokōhau National Historical Park, Hawai' $i$ : U.S. Geological Survey Scientific Investigations Report 2006-5256, 62 p., accessed April 23, 2020, at https://pubs. usgs.gov/sir/2006/5256/.

Hammer, J.E., Coombs, M.L., Shamberger, P.J., and Kimura, J.-I., 2006, Submarine sliver in North Kona-A window into the early magmatic and growth history of Hualalai Volcano, Hawaii: Journal of Volcanology and Geothermal Research, v. 151, no. 1-3, p. 157-188, accessed April 23, 2020, at https://doi.org/10.1016/j.jvolgeores.2005.07.028.

Holcomb, R.T., Nelson, B.K., Reiners, P.W., and Sawyer, N.-L., 2000, Overlapping volcanoes - The origin of Hilo Ridge, Hawaii: Geology, v. 28, no. 6, p. 547-550, accessed April 23, 2020, at https://doi.org/10.1130/00917613(2000)28<547:OVTOOH $>2.0 . \mathrm{CO} ; 2$.

Holthuis, L.B., 1973, Caridean shrimps found in land-locked saltwater pools at four Indo-West Pacific localities (Sinai Peninsula, Funafuti Atoll, Maui and Hawaii Islands), with the description of one new genus and four new species: Zoologische Verhandelingen, no. 128, 48 p., accessed April 23, 2020, at https://www.repository.naturalis.nl/ document/149069.
Horai, K.-I., 1991, Thermal conductivity of Hawaiian basaltA new interpretation of Robertson and Peck's data: Journal of Geophysical Research-Solid Earth, v. 96, no. B3, p. 4125-4132, accessed April 23, 2020, at https://doi. org/10.1029/90JB02452.

Hughes, J.D., and Sanford, W.E., 2004, SUTRA-MS a version of SUTRA modified to simulate heat and multiplesolute transport: U.S. Geological Survey Open-File Report 2004-1207, 141 p., accessed April 23, 2020, at https://pubs. usgs.gov/of/2004/1207/.

Johnson, G.R., 1980, Porosity and density of Kilauea Volcano basalts, Hawaii: U.S. Geological Survey Professional Paper 1123-B, 6 p., accessed April 23, 2020, at https://doi. org/10.3133/pp1123AD.

Juvik, J.O., Singleton, D.C., and Clarke, G.G., 1978, Climate and water balance on the island of Hawaii, in Miller, J., ed., Mauna Loa Observatory-A twentieth anniversary report: U.S. Department of Commerce, National Oceanic and Atmospheric Administration Environmental Research Laboratories, p. 129-139, accessed April 23, 2020, at https://babel.hathitrust.org/cgi/pt?id=uc1.31822025465287 \&view=1up\&seq=143.

Juvik, S.O., and Juvik, J.O., 1998, Atlas of Hawai'i (3d ed.): Honolulu, University of Hawai'i Press, 333 p.

Kagawa-Viviani, A.K., and Giambelluca, T.W., 2020, Spatial patterns and trends in surface air temperatures and implied changes in atmospheric moisture across the Hawaiian Islands, 1905-2017: Journal of Geophysical ResearchAtmospheres, v. 125, no. 2, accessed April 28, 2020, at https://doi.org/10.1029/2019JD031571.

Kauahikaua, J., 1993, Geophysical characteristics of the hydrothermal systems of Kilauea Volcano, Hawai' $i$ : Geothermics, v. 22, no. 4, p. 271-299, accessed August 29, 2019, at https://doi.org/10.1016/0375-6505(93)90004-7.

Kauahikaua, J.P., and Camara, B., 2000, Most recent eruptions of Hualālai volcano, Hawai' $i$ - Geological evidence from the historical record: Geological Society of America Special Paper 345, p. 25-32, accessed April 23, 2020, at https://doi. org/10.1130/0-8137-2345-0.25.

Kauahikaua, J.P., Duarte, K., and Foster, J., 1998, A preliminary gravity survey of the Kailua-Kona area, Hawai' $i$, for delineation of a hydrologic boundary: U.S. Geological Survey Open-File Report 98-110, 21 p., accessed January 20, 2021, at https://doi.org/10.3133/ ofr98110.

Kauahikaua, J., Hildenbrand, T., and Webring, M., 2000, Deep magmatic structures of Hawaiian volcanoes, imaged by three-dimensional gravity models: Geology, v. 28, no. 10, p. 883-886, accessed February 17, 2021, at https://doi. org/10.1130/0091-7613(2000)28\%3C883:DMSOHV\%3E2. $0 . \mathrm{CO} ; 2$. 
Kinoshita, W.T., 1965, A gravity survey of the island of Hawaii: Pacific Science, v. 19, no. 3, p. 339-340, accessed April 23, 2020, at http://hdl.handle.net/10125/10754.

Kinoshita, W.T., Krivoy, H.L., Mabey, D.R., and Macdonald, R.R., 1963, Gravity survey of the island of Hawaii: U.S. Geological Survey Professional Paper 475-C, p. C114C116, accessed April 23, 2020, at https://pubs.er.usgs.gov/ publication/pp475C.

Kreyns, P., Geng, X., and Michael, H.A., 2020, The influence of connected heterogeneity on groundwater flow and salinity distributions in coastal volcanic aquifers: Journal of Hydrology, v. 586, accessed on April 8, 2020, at https://doi. org/10.1016/j.jhydrol.2020.124863.

Langenheim, V.A.M., and Clague, D.A., 1987, The HawaiianEmperor volcanic chain, part II, stratigraphic framework of volcanic rocks of the Hawaiian Islands, chap. 1 of Decker, R.W., Wright, T.L., and Stauffer, P.H., eds., Volcanism in Hawaii: U.S. Geological Survey Professional Paper 1350, v. 1, p. 55-84, accessed April 23, 2020, at https://pubs.usgs. gov/pp/1987/1350/.

Lipman, P.W., and Coombs, M.L., 2006, North Kona slumpSubmarine flank failure during the early(?) tholeiitic shield stage of Hualalai Volcano: Journal of Volcanology and Geothermal Research, v. 151, no. 1-3, p. 189-216, accessed April 23, 2020, at https://doi.org/10.1016/j. jvolgeores.2005.07.029.

Lipman, P.W., Normark, W.R., Moore, J.G., Wilson, J.B., and Gutmacher, C.E., 1988, The giant submarine Alika debris slide, Mauna Loa, Hawaii: Journal of Geophysical Research-Solid Earth, v. 93, no. B5, p. 4279-4299, accessed April 23, 2020, at https://doi.org/10.1029/ JB093iB05p04279.

Lucas, R., 2013, Hawaii Ocean Timeseries (HOT) physical oceanography: Hawaii Ocean Timeseries database, accessed May 31, 2013, at http://www.soest.hawaii.edu/HOT_ WOCE/ftp.html.

Macdonald, G.A., Abbott, A.T., and Peterson, F.L., 1983, Volcanoes in the sea-The geology of Hawaii ( $2 \mathrm{~d}$ ed.): Honolulu, University of Hawai'i Press, 517 p.

Millero, F.J., Perron, G., and Desnoyers, J.E., 1973, Heat capacity of seawater solutions from $5^{\circ}$ to $35^{\circ} \mathrm{C}$ and 0.5 to $22 \%$ chlorinity: Journal of Geophysical ResearchOceans and Atmospheres, v. 78, no. 21, p. 4499-4507, accessed April 23, 2020, at https://doi.org/10.1029/ JC078i021p04499.

Mitchell, C., Ogura, C., Meadows, D.W., Kane, A., Strommer, L., Fretz, S., Leonard, D., and McClung, A., 2005, Hawaii's comprehensive wildlife conservation strategy: Department of Land and Natural Resources, Honolulu, Hawai ${ }^{`} i, 722$ p., accessed January 20, 2021, at https:/dlnr.hawaii.gov/wildlife/ files/2013/09/CWCS-Full-Document-2005Oct01.pdf.
Moore, J.G., and Clague, D., 1987, Coastal lava flows from Mauna Loa and Hualalai volcanoes, Kona, Hawaii: Bulletin of Volcanology, v. 49, no. 6, p. 752-764, accessed April 23, 2020, at https://doi.org/10.1007/BF01079826.

Moore, J.G., and Clague, D.A., 1992, Volcano growth and evolution of the island of Hawaii: Geological Society of America Bulletin, v. 104, no. 11, p. 1471-1484, accessed April 23, 2020, at https://doi.org/10.1130/00167606(1992)104<1471:VGAEOT>2.3.CO;2.

Moore, J.G., Clague, D.A., Holcomb, R.T., Lipman, P.W., Normark, W.R., and Torresan, M.E., 1989, Prodigious submarine landslides on the Hawaiian ridge: Journal of Geophysical Research-Solid Earth, v. 94, no. B12, p. 17465-17484, accessed April 23, 2020, at https://doi. org/10.1029/JB094iB12p17465.

Moore, J.G., Clague, D.A., Meyer, R., and Bohrson, W.A., 1987, Hualalai volcano-A preliminary summary of geologic, petrologic, and geophysical data, chap. 20 of Decker, R.W., Wright, T.L., and Stauffer, P.H., eds., Volcanism in Hawaii: U.S. Geological Survey Professional Paper 1350, v. 1, p. 571-585, accessed April 23, 2020, at https://pubs.usgs.gov/pp/1987/1350/.

Moore, J.G., and Fornari, D.J., 1984, Drowned reefs as indicators of the rate of subsidence of the Island of Hawai' $\mathrm{i}$ : The Journal of Geology, v. 92, no. 6, p. 752-759, accessed April 23, 2020, at https://www.jstor.org/stable/30070505.

Moore, J.G., Normark, W.R., and Holcomb, R.T., 1994, Giant Hawaiian landslides: Annual Review of Earth and Planetary Sciences, v. 22, p. 119-144, accessed April 23, 2020, at https://doi.org/10.1146/annurev.ea.22.050194.001003.

National Climatic Data Center, 2013a, Climate data online: National Oceanic and Atmospheric Administration, National Climatic Data Center online data, accessed July 31, 2013, at https://www.ncdc.noaa.gov/cdo-web/.

National Climatic Data Center, 2013b, Climate normal: National Oceanic and Atmospheric Administration, National Climatic Data Center online data, accessed July 31, 2013, at http://www1.ncdc.noaa.gov/pub/data/normals/1981-2010/ products/auxiliary/station/USC00513911.normals.txt.

National Oceanic and Atmospheric Administration, 2010, Tides and currents, Kawaihae, Hawai' $i$, station 1617433: National Oceanic and Atmospheric Administration web page, accessed April 13, 2012, at http://tidesandcurrents. noaa.gov/.

National Park Service, 2019, Pacific Island Network water quality monitoring dataset: Integrated Resource Management Applications (IRMA) relational database, digital file PACN_water_quality_be_certified_20190418_ non-sensitive.mdb, accessed April 14, 2020, at https:/irma. nps.gov/Datastore/Reference/Profile/2260084. 
Nullet, D., and Sanderson, M., 1993, Radiation and energy balances and air temperature, chap. 3 of Sanderson, M., ed., Prevailing trade winds: Honolulu, University of Hawai'i Press, p. 37-55.

Oki, D.S., 1999, Geohydrology and numerical simulation of the ground-water flow system of Kona, island of Hawaii: U.S. Geological Survey Water-Resources Investigations Report 99-4073, 70 p., accessed June 18, 2020, at https:// pubs.usgs.gov/wri/1999/4073/.

Oki, D.S., 2021, SUTRA model used to evaluate the effects of groundwater withdrawal and injection, Kaloko-Honokōhau National Historical Park, Hawai ${ }^{i}$ : U.S. Geological Survey data release, https://doi.org/10.5066/P9IZ3EVJ.

Oki, D.S., Tribble, G.W., Souza, W.R., and Bolke, E.L., 1999, Ground-water resources in Kaloko-Honokohau National Historical Park, island of Hawaii, and numerical simulation of the effects of ground-water withdrawals: U.S. Geological Survey Water-Resources Investigations Report 99-4070, 49 p., accessed April 23, 2020, at https://pubs.usgs.gov/ wri/1999/4070/.

Olson, K., 2018, Annual report for the comprehensive environmental monitoring program covering the period July 24, 1982 through June 30, 2018: Natural Energy Laboratory of Hawaii Authority, 51 p. plus appendixes, accessed April 13, 2020, at https://nelha.hawaii.gov/resources/library/ nelha-lab-reports/.

Ramires, M.L.V., Nieto de Castro, C.A., Nagasaka, Y., Nagashima, A., Assael, M.J., and Wakeham, W.A., 1995, Standard reference data for the thermal conductivity of water: Journal of Physical and Chemical Reference Data, v. 24, no. 3, p. 1377-1381, accessed April 23, 2020, at https:// doi.org/10.1063/1.555963.

Richmond, B.M., Gibbs, A.E., and Cochran, S.A., 2008, Geologic resource evaluation of Kaloko-Honokōhau National Historical Park, Hawai' i; Geology and coastal landforms: U.S. Geological Survey Open-File Report 2008-1191, 28 p., accessed April 23, 2020, at https://pubs. usgs.gov/of/2008/1191/.

Robertson, E.C., and Peck, D.L., 1974, Thermal conductivity of vesicular basalt from Hawaii: Journal of Geophysical Research — Solid Earth and Planets, v. 79, no. 32, p. 48754888, accessed April 23, 2020, at https://doi.org/10.1029/ JB079i032p04875.

Rotzoll, K., 2010, Effects of groundwater withdrawal on borehole flow and salinity measured in deep monitor wells in Hawai' $\mathrm{i}$-Implications for groundwater management: U.S. Geological Survey Scientific Investigations Report 2010-5058, 42 p., accessed April 23, 2020, at https://pubs. usgs.gov/sir/2010/5058/.
Rotzoll, K., 2012, Numerical simulation of flow in deep open boreholes in a coastal freshwater lens, Pearl Harbor Aquifer, O`ahu, Hawai'i: U.S. Geological Survey Scientific Investigations Report 2012-5009, 39 p., accessed April 23, 2020, at https://pubs.usgs.gov/sir/2012/5009/.

Rotzoll, K., El-Kadi, A.I., and Gingerich, S.B., 2008, Analysis of an unconfined aquifer subject to asynchronous dualtide propagation: Ground Water, v. 46, no. 2, p. 239-250, accessed April 23, 2020, at https://doi.org/10.1111/j.17456584.2007.00412.x.

Roy, R.F., Beck, A.E., and Touloukian, Y.S., 1989, Thermophysical properties of rocks, chap. 12 of Touloukian, Y.S., Judd, W.R., and Roy, R.F., eds. Physical properties of rocks and minerals: CINDAS Data Series on Material Properties, v. II-2, p. 409-502.

Sandwell, D.T., 1987, Biharmonic spline interpolation of GEOS-3 and SEASAT altimeter data: Geophysical Research Letters, v. 14, no. 2, p. 139-142, accessed June 18, 2020, at https://doi.org/10.1029/GL014i002p00139.

Sharqawy, M.H., Lienhard, J.H., V, and Zubair, S.M., 2010, Thermophysical properties of seawater-A review of existing correlations and data: Desalination and Water Treatment, v. 16, no. 1-3, p. 354-380, accessed April 23, 2020, at https://doi.org/10.5004/dwt.2010.1079.

Sherrod, D.R., Sinton, J.M., Watkins, S.E., and Brunt, K.M., 2007, Geologic map of the State of Hawai'i: U.S. Geological Survey Open-File Report 2007-1089, 83 p., 8 plates, scales 1:100,000 and 1:250,000, with GIS database, accessed November 15, 2018, at https://doi. org/10.3133/ofr20071089.

Silliman, S.E., and Frost, C., 1998, Monitoring hydraulic gradient using three-point estimator: Journal of Environmental Engineering, v. 124, no. 6, p. 517-523, accessed November 30, 2020, at https://doi.org/10.1061/ (ASCE)0733-9372(1998)124:6(517).

Souza, W.R., and Voss, C.I., 1987, Analysis of an anisotropic coastal aquifer system using variable-density flow and solute transport simulation: Journal of Hydrology, v. 92, no. 1-2, p. 17-41, accessed April 23, 2020, at https://doi. org/10.1016/0022-1694(87)90087-4.

State of Hawai'i, 2001, The State of Hawaii data book 2000, a statistical abstract: State of Hawai' $i$, Department of Business, Economic Development, and Tourism, accessed July 29, 2013, at http://dbedt.hawaii.gov/economic/ databook/db2000/.

State of Hawai'i, 2011, The State of Hawaii data book 2010, a statistical abstract: State of Hawai' $i$, Department of Business, Economic Development, and Tourism, accessed July 29, 2013, at http://dbedt.hawaii.gov/economic/ databook/db2010/. 
State of Hawai'i, 2020, Keopu 1 Deep Monitor Well, Hawaii (8-3858-001), fluctuations in the water table, top of transition zone (TTZ), midpoint of transition zone (MPTZ), and sea water from August 2016 through December 2019 (last updated 12/27/2019): Commission on Water Resource Management, accessed March 25, 2020, at https://dlnr. hawaii.gov/cwrm/groundwater/monitoring/.

Stearns, H.T., 1978, Quaternary shorelines in the Hawaiian Islands: Honolulu, Bishop Museum Press, Bernice P. Bishop Museum Bulletin 237, 57 p., accessed April 23, 2020, at http://hbs.bishopmuseum.org/pubs-online/pdf/bull237.pdf.

Stearns, H.T., 1985, Geology of the state of Hawaii (2d ed.): Palo Alto, Calif., Pacific Books Publishers, 335 p.

Stearns, H.T., and Macdonald, G.A., 1946, Geology and ground-water resources of the island of Hawaii: Hawai' $i$ Division of Hydrography Bulletin 9, 363 p., accessed April 23, 2020, at http://hdl.handle.net/10125/50781.

Sun, H., Feistel, R., Koch, M., and Markoe, A., 2008, New equations for density, entropy, heat capacity, and potential temperature of a saline thermal fluid: Deep-Sea Research I, v. 55, no. 10, p. 1304-1310, accessed April 23, 2020, at https://doi.org/10.1016/j.dsr.2008.05.011.

Tango, L.K.K., 2010, The effect of salinity and temperature on survival of the orange-black Hawaiian damselfly, Megalagrion xanthomelas: Hilo, Hawai'i, University of Hawai'i at Hilo, M.S. thesis, 46 p.

Tillman, F.D., Oki, D.S., Johnson, A.G., Barber, L.B., and Beisner, K.R., 2014, Investigation of geochemical indicators to evaluate the connection between inland and coastal groundwater systems near Kaloko-Honokōhau National Historical Park, Hawai'i: Applied Geochemistry, v. 51, p. 278-292, accessed April 23, 2020, at https://doi. org/10.1016/j.apgeochem.2014.10.003.

Tom Nance Water Resource Engineering, 2002, Assessment of the potential impact on water resources of the proposed Kaloko-Honokohau Business Park in North Kona, Hawaii: Appendix 3 of Final Environmental Impact Statement, Kaloko-Honokohau Business Park, 32 p.

U.S. Geological Survey, 2020, USGS water data for the nation: U.S. Geological Survey National Water Information System web page, accessed May 26, 2016, at https://dx.doi. org/10.5066/F7P55KJN.

Voss, C.I., 1999, USGS SUTRA code-History, practical use, and application in Hawaii, chap. 9 of Bear, J., Cheng, A.H.-D., Sorek, S., Ouazar, D., and Herrera, I., eds., Seawater intrusion in coastal aquifers-Concepts, methods, and practices: Dordrecht, Kluwer Academic Publishers, p. 249-313.
Voss, C.I., and Provost, A.M., 2010, SUTRA, A model for saturated-unsaturated variable-density ground-water flow with solute or energy transport: U.S. Geological Survey Water-Resources Investigations Report 02-4231, 291 p., accessed April 23, 2020, at https://water.usgs.gov/waterresources/software/sutra/SUTRA_2_2-documentation.pdf.

Water Resource Associates, 2007, Hydrogeologic feasibility study for a high-level water development shaft at Keopu, North Kona, Hawaii: Report prepared for Hawai' ${ }^{i} i$ Department of Land and Natural Resources, Engineering Division, Honolulu, Hawai'i, 71 p. plus appendixes.

Wentworth, C.K., 1938a, Ash formations of the island Hawaii-Third special report of the Hawaiian Volcano Observatory of Hawaii National Park and the Hawaiian Volcano Research Association: Honolulu, Hawaiian Volcano Research Association, 183 p., accessed March 12, 2020, at https://babel.hathitrust.org/cgi/pt?id=uc1.31822033841404 $\&$ view $=1$ up\&seq $=1$.

Wentworth, C.K., 1938b, Geology and ground water resources of the Palolo-Waialae District: Honolulu, Honolulu Board of Water Supply, 274 p., accessed April 23, 2020, at http:// hdl.handle.net/10524/36143.

Wentworth, C.K., 1939, The specific gravity of sea water and the Ghyben-Herzberg ratio at Honolulu: University of Hawaii Bulletin, v. 18, no. 8, 24 p.

Wentworth, C.K., and Macdonald, G.A., 1953, Structures and forms of basaltic rocks in Hawaii: U.S. Geological Survey Bulletin 994, 98 p., accessed June 18, 2020, at https://doi. org/10.3133/b994.

Wolfe, E.W., and Morris, J., 1996, Geologic map of the island of Hawaii: U.S. Geological Survey Miscellaneous Investigations Series Map I-2524-A, 1:100,000 scale, accessed April 23, 2020, at https://doi.org/10.3133/i2524A.

Yamasaki, S., Kani, T., Hanan, B.B., and Tagami, T., 2009, Isotopic geochemistry of Hualalai shield-stage tholeiitic basalts from submarine North Kona region, Hawaii: Journal of Volcanology and Geothermal Research, v. 185, no. 3, p. 223-230, accessed April 23, 2020, at https://doi. org/10.1016/j.jvolgeores.2009.06.006.

Zucca, J.J., Hill, D.P., and Kovach, R.L., 1982, Crustal structure of Mauna Loa Volcano, Hawaii, from seismic refraction and gravity data: Bulletin of the Seismological Society of America, v. 72, no. 5, p. 1535-1550, accessed April 23, 2020, at https://pubs.geoscienceworld.org/ssa/ bssa/article-abstract/72/5/1535/102082/Crustal-structure-ofMauna-Loa-Volcano-Hawaii-from?redirectedFrom=fulltext. 
Moffett Field Publishing Service Center, California

Manuscript approved for publication January 15, 2021

Edited by Katherine Jacques

Illustration support by JoJo Mangano

Layout and design by Kimber Petersen 


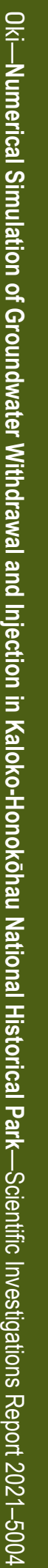

